\title{
A multivariate dynamic linear model for early warnings of diarrhea and pen fouling in slaughter pigs
}

Jensen, Dan B.

Published in:

Up to date with pig

Publication date:

2016

Document version

Publisher's PDF, also known as Version of record

Document license:

Unspecified

Citation for published version (APA):

Jensen, D. B. (2016). A multivariate dynamic linear model for early warnings of diarrhea and pen fouling in slaughter pigs. In Up to date with pig: Book of presentations of the 3 CPH Pig seminar

http://cphpig.ku.dk/dokumenter/seminar/Book_of_Presentations_CPH_Pig_seminar_2016.pdf 
THE FACULTY OF HEALTH AND MEDICAL SCIENCES

UNIVERSITY OF COPENHAGEN

CENTER FOR RESEARCH IN PIG PRODUCTION AND HEALTH

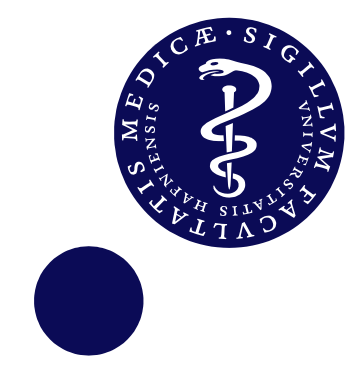

Book of presentations of the $3^{\text {rd }} \mathrm{CPH}$ Pig seminar February 3, 2016

\section{Up to Date with Pig Research}

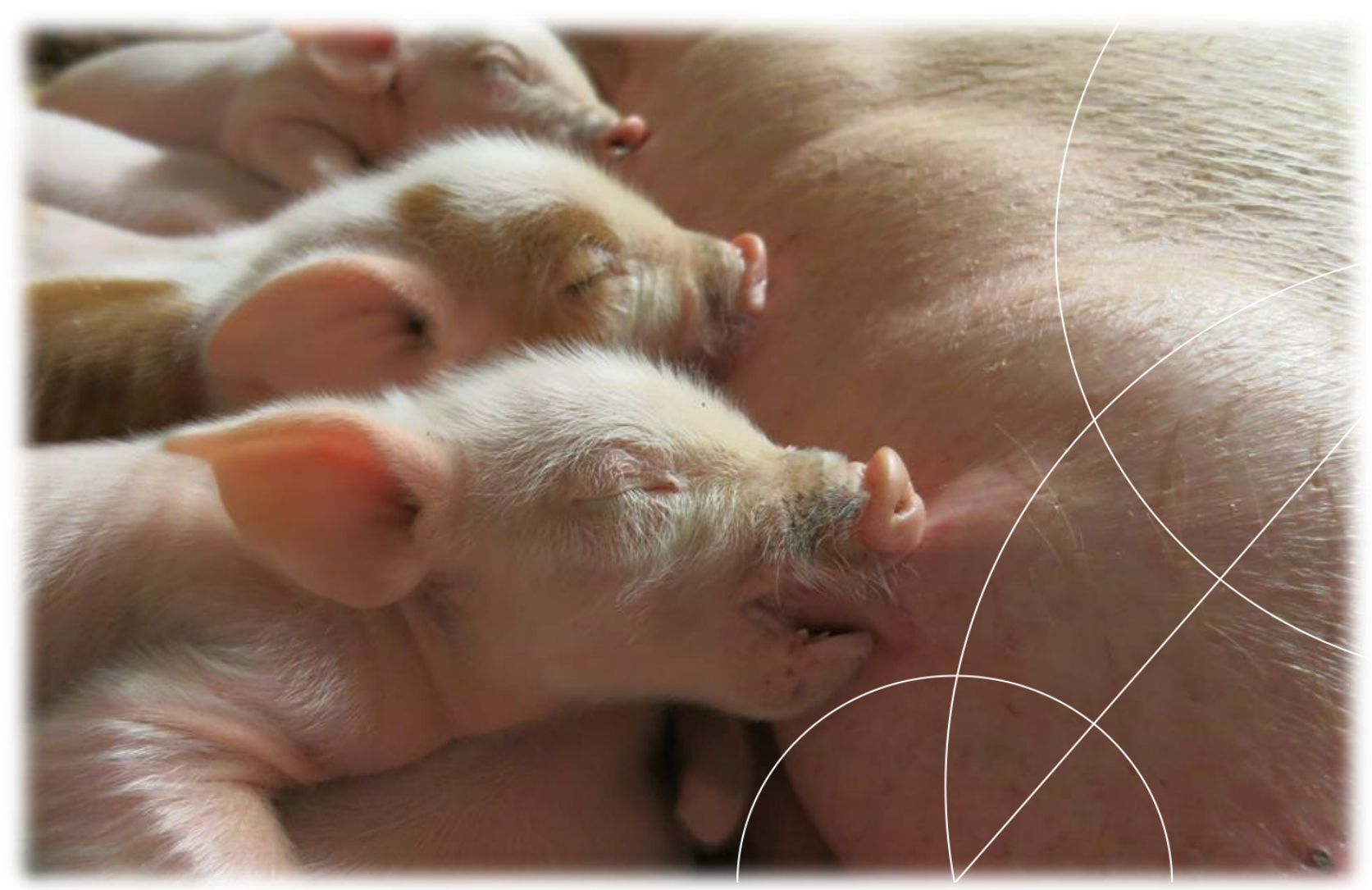




\section{Table of Contents}

Programme

List of participants vi

Key Lecture: Benefits of linking universities and the Danish pig industry - from the industry's point of view

Session 1: Growing Pigs

PCV2 infection dynamics: Diagnostics, between-batch consistency and correlation to productivity parameters.

A multivariate dynamic linear model for early warnings of diarrhea and pen fouling in slaughter pigs. 13

Osteomyelitis in Danish slaugther pigs

Monitoring growth in finishers by weighing selected groups of pigs

Session 2: Sows and Piglets .

Monitoring PRRS using laboratory data

Impact of feeding regime on growth in prepubertal gilts

Increasing the dietary level of protein for lactating sows affects litter gain and sow weight loss 45

Gastric emptying rate and blood values in newborn intra-uterine growth restricted piglets......

Session 3: Welfare 57

The use of virtual herds in veterinary and agricultural education 59

Assessing farms with the Danish animal welfare index 67

Tail biting: prevalence among docked and undocked pigs from weaning to slaughter. 73

Loose housed sows with low piglet mortality 79

Session 4: MRSA 85

Levels of MRSA on pigs and environmental samples..... 87

Can we reduce MRSA ST398 in positive farms by eliminating a few pig carriers? 93

How to pool fecal samples in a cross-sectional study of antimicrobial resistance genes in Danish pig herds.

Can pooled faecal samples be used for resistance profiling? -Resistance in E. coli isolates from diarrhoeic nursery pigs 


\section{Preface}

The Center for research in pig production and health - CPH Pig - enhances, consolidates and raises the profile of pig production research. The importance of research and innovation for the Danish pork industry remains crucial. The Danish pig producers face tight financial pressures and many factors contribute to the volatility surrounding the pork industry. The production of finishers in Denmark is declining as producers export a significant and increasing number of weaners to be finished elsewhere in Europe. A goal of CPH Pig is, in collaboration with its many partners, to support the Danish pig industry with R\&D that is essential in addressing drivers of a profitable and sustainable pork production in a global market.

The 2016 seminar presents the recent developments across a diverse range of disciplines impacting on pig production particularly on increased productivity, survival among piglets, MRSA, reduction in antibiotic usage and objective measurements of animal welfare. With this in mind, the research presentations of the CPH Pig seminar will cover four main themes: "Growing pigs", "Sows and Piglets", "Welfare" and "MRSA". It is our hope that this third CPH Pig seminar will provide an excellent forum to present new findings, foster in-depth discussions, and hopefully provide solutions to some of the industry's challenges.

The University of Copenhagen and $\mathrm{CPH}$ Pig are integral in the training of undergraduate and postgraduate students and generating junior scientists who are essential to the future of the industry. CPH Pig outwardly promotes the involvement of students and early-career scientists at the meeting. The seminar again has a considerable number of young scientists attending and presenting their work and for many it will be their first opportunity to interact with key industry figures and organisations.

It is a pleasure to direct the $\mathrm{CPH}$ Pig seminar and contribute to facilitating the networking of those involved in pig research and pork production. This seminar is possible because a dedicated group of individuals coordinated and arranged all aspects of the event. We wish to thank everyone for their contribution and dedication. However, most importantly, thank you for participating and making the seminar a great success. Thank you for your support and we hope you will continue to be part of the future achievements of the center.

Hans Henrik Dietz

Chairman
Christian Fink Hansen

Center Director 


\section{CPH Pig Seminar February 3, 2016 \\ Up to Date with Pig Research}

\begin{tabular}{|c|c|c|}
\hline Time & Presenters & Title \\
\hline 9:00-9:10 & $\begin{array}{l}\text { Hans Henrik Dietz } \\
\text { Head of Department, Department of Large } \\
\text { Animal Sciences, University of Copenhagen }\end{array}$ & Welcome \\
\hline 9:10-9:30 & $\begin{array}{l}\text { Jens Ulrich Nielsen } \\
\text { Director, Innovation, SEGES Pig Research } \\
\text { Centre }\end{array}$ & $\begin{array}{l}\text { Key Lecture: Benefits of linking } \\
\text { universities and the Danish pig industry - } \\
\text { from the industry's point of view }\end{array}$ \\
\hline \multicolumn{2}{|c|}{ Session 1: Growing pigs } & Chair: Jens Peter Nielsen \\
\hline 9:30-9:45 & $\begin{array}{l}\text { Gitte Blach Nielsen, } \\
\text { Industrial PhD student, Department of Large } \\
\text { Animal Sciences, University of Copenhagen \& } \\
\text { MSD Animal Health }\end{array}$ & $\begin{array}{l}\text { PCV2 infection dynamics: } \\
\text { Diagnostics, between-batch consistency } \\
\text { and correlation to productivity } \\
\text { parameters }\end{array}$ \\
\hline 9:45-10:00 & $\begin{array}{l}\text { Dan Børge Jensen, } \\
\text { PhD student, Department of Large Animal } \\
\text { Sciences, University of Copenhagen }\end{array}$ & $\begin{array}{l}\text { A multivariate dynamic linear model for } \\
\text { early warnings of diarrhea and pen fouling } \\
\text { in slaughter pigs }\end{array}$ \\
\hline 10:00-10:15 & $\begin{array}{l}\text { Louise Kruse Jensen } \\
\text { Assistant Professor, Department of Veterinary } \\
\text { Disease Biology, University of Copenhagen }\end{array}$ & Osteomyelitis in Danish slaughter pigs \\
\hline $10: 15-10: 30$ & $\begin{array}{l}\text { Anna Helena Stygar, } \\
\text { Post doc., Department of Large Animal } \\
\text { Sciences, University of Copenhagen }\end{array}$ & $\begin{array}{l}\text { Monitoring growth in finishers by } \\
\text { weighing selected groups of pigs }\end{array}$ \\
\hline $10: 30-11: 00$ & MORNING TEA/COFFEE & \\
\hline Session 2: Sov & ws and Piglets & Chair: Anne-Helene Tauson \\
\hline $11: 00-11: 15$ & $\begin{array}{l}\text { Ana Carolina Lopes Antunes } \\
\text { PhD Student, DTU National Veterinary } \\
\text { Institute }\end{array}$ & Monitoring PRRS using laboratory data \\
\hline $11: 15-11: 30$ & $\begin{array}{l}\text { Sophie Van Vliet } \\
\text { PhD student, Aarhus University }\end{array}$ & $\begin{array}{l}\text { Impact of feeding regime on growth in } \\
\text { prepubertal gilts }\end{array}$ \\
\hline $11: 30-11: 45$ & $\begin{array}{l}\text { Thomas S } \varnothing \text { nderby Bruun, } \\
\text { Senior Specialist, SEGES Pig Research Centre }\end{array}$ & $\begin{array}{l}\text { Increasing the dietary level of protein for } \\
\text { lactating sows affects litter gain and sow } \\
\text { weight loss }\end{array}$ \\
\hline $11: 45-12: 00$ & $\begin{array}{l}\text { Charlotte Amdi Williams, } \\
\text { Post doc., Department of Large Animal } \\
\text { Sciences, University of Copenhagen }\end{array}$ & $\begin{array}{l}\text { Gastric emptying rate and blood values in } \\
\text { newborn intra-uterine growth restricted } \\
\text { piglets }\end{array}$ \\
\hline $12: 00-13: 00$ & LUNCH & \\
\hline
\end{tabular}




\begin{tabular}{|c|c|c|}
\hline \multicolumn{2}{|c|}{ Session 3: Welfare } & \multirow{2}{*}{$\begin{array}{l}\text { Chair: Björn Forkman } \\
\text { The use of virtual herds in veterinary and } \\
\text { agricultural education }\end{array}$} \\
\hline $13: 00-13: 15$ & $\begin{array}{l}\text { Karl Johan Møller Klit } \\
\text { PhD student, Department of Large Animal } \\
\text { Sciences, University of Copenhagen }\end{array}$ & \\
\hline $13: 15-13: 30$ & $\begin{array}{l}\text { Marlene Kirchner } \\
\text { Assistant Professor, Department of Large } \\
\text { Animal Sciences, University of Copenhagen }\end{array}$ & $\begin{array}{l}\text { Assessing farms with the Danish animal } \\
\text { welfare index }\end{array}$ \\
\hline $13: 30-13: 45$ & $\begin{array}{l}\text { Helle Pelant Lahrmann } \\
\text { Industrial PhD student, Department of Large } \\
\text { Animal Sciences, University of Copenhagen \& } \\
\text { SEGES Pig Research Centre }\end{array}$ & $\begin{array}{l}\text { Tail biting: prevalence among docked and } \\
\text { undocked pigs from weaning to slaughter }\end{array}$ \\
\hline $13: 45-14: 00$ & $\begin{array}{l}\text { Janni Hales Pedersen } \\
\text { Post doc., Department of Large Animal } \\
\text { Sciences, University of Copenhagen }\end{array}$ & $\begin{array}{l}\text { Loose housed sows with low piglet } \\
\text { mortality }\end{array}$ \\
\hline $14: 00-14: 30$ & AFTERNOON TEA/COFFEE & \\
\hline Session 4: MF & & Chair: Anders Miki Boyesen \\
\hline $14: 30-14: 45$ & $\begin{array}{l}\text { Julie Elvekjær Hansen } \\
\text { PhD student, DTU National Veterinary } \\
\text { Institute }\end{array}$ & $\begin{array}{l}\text { Levels of MRSA on pigs and environmental } \\
\text { samples }\end{array}$ \\
\hline $14: 45-15: 00$ & $\begin{array}{l}\text { Carmen Espinosa-Gongora } \\
\text { Post doc., Department of Veterinary Disease } \\
\text { Biology, University of Copenhagen }\end{array}$ & $\begin{array}{l}\text { Can we reduce MRSA ST398 in positive } \\
\text { farms by eliminating a few pig carriers? }\end{array}$ \\
\hline $15: 00-15: 15$ & $\begin{array}{l}\text { Anna Camilla Birkegård } \\
\text { PhD student, DTU National Veterinary } \\
\text { Institute }\end{array}$ & $\begin{array}{l}\text { How to pool fecal samples in a cross- } \\
\text { sectional study of antimicrobial resistance } \\
\text { genes in Danish pig herds }\end{array}$ \\
\hline $15: 15-15: 30$ & $\begin{array}{l}\text { Nicolai Weber, } \\
\text { PhD student, Department of Large Animal } \\
\text { Sciences, University of Copenhagen }\end{array}$ & $\begin{array}{l}\text { Can pooled faecal samples be used for } \\
\text { resistance profiling? -Resistance in } E \text {. coli } \\
\text { isolates from diarrhoeic nursery pigs? }\end{array}$ \\
\hline $15: 30-15: 35$ & $\begin{array}{l}\text { Christian Fink Hansen } \\
\text { Professor, Department of Large Animal } \\
\text { Sciences, University of Copenhagen } \\
\end{array}$ & Concluding remarks \\
\hline
\end{tabular}

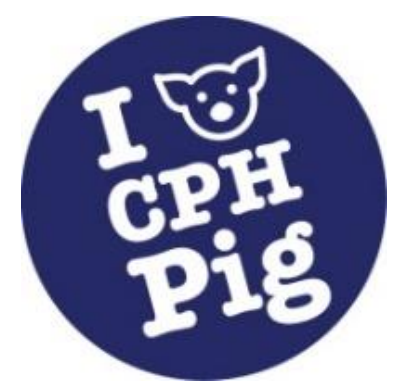

www.cphpig.ku.dk 


\section{List of participants}

Amanda Brinch Kruse

Anja Annine Haagaard

Ana Carolina Lopes Antunes

Andreas Grav Eriksen

Andreas Birch

Andreas Klit

Anita Strøm Pedersen

Anna Camilla Birkegård

Anna Helena Stygar

Anne Mette Strunz Hanl

Anne Schultz

Anne Wolfenberg

Anne-Charlotte Olsson

Anne-Helene Tauson

Annette Bech

Annette Riddersholm Kristensen

Arne $M$ Hansen

Arshnee Moodley

Asger Lundorff Jensen

Astrid Larberg

Bent-Ole Andersen

Birgit Nørrung

Birgitte Ask

Bjarne Ellegaard

Björn Forkman

Brian Eskildsen

Camilla Kaae Højgaard

Camilla Sara Birch Sørensen

Carmen Espinosa Gongora

Caroline Kold Simonsen

Charlotte Amdi Williams

Charlotte Sonne Kristensen

Chiara Trevisan

Chris Knight

Christian Fink Hansen

Christina Johansen

Christine Lunddahl

Claus Fertin

Claus Hansen

Dagim Belay

Dan Jensen
PhD student, University of Copenhagen

DVM, Veterinarian

PhD student, DTU Vet

Svinefagdyrlæge

Dyrlæge, Øvet

Studerende, Veterinærmedicin

Dyrlæge, Fødevarestyrelsen

PhD student, DTU Vet

Post doc., University of Copenhagen, IPH

DVM, Hipra Danmark Aps

Stud.med.vet., SUND

Journalist, L-mediehus

Agronomist, Sveriges Lantbruksuniversitet

Professor, University of Copenhagen, IKVH

Technical Account Manager, Elanco

Konsulent, DK-Svinerådgivning

Konsulent, Københavns Universitet

Associate Professor, University of Copenhagen

Institutleder, IKVH, SUND, KU

PhD student, University of Copenhagen

Kommunikationsmedarbejder, IPH

Institutleder, Inst. for Veterinær Sygdomsbiologi

Chefforsker, SEGES, VSP-Avl

Dyrlæge, MSD AH

Professor, KU

Produktudviklingskonsulent, Agronom

MSc. student in Animal Science, University of Copenhagen

Studerende, Erhvervakademiet Sjælland

Post doc., University of Copenhagen, IVS

Svinerådgiver, LandboNord

Post doc., University of Copenhagen, IPH

DVM, SEGES Pig Research Centre

PhD Student, University of Copenhagen

Professor, UCPH

Professor, University of Copenhagen, IPH

Student, Veterinærmedicin

Student, Veterinary Medicine

Direkt $\varnothing r$, SEGES Videncenter for Svineproduktion

Chefforsker, SEGES, Videncenter for Svineproduktion

Mr., IFRO

PhD student, University of Copenhagen 
Danielle Kjerulff Funk Petersen

Ebbe Reinhold Nielsen

Eline Palm Hansen

Elisabeth Okholm Nielsen

Erik Larsen

Esben $\varnothing$. Eriksen

Flemming Thorup

Franziska Hakansson

Fredrik Engström

Gianluca Mazzoni

Gitte Blach Nielsen

Haja Kadarmideen

Hanne Justesen

Hanne Kongsted

Hans Henrik Dietz

Hans Houe

Hans Aae

Heidi Brisk

Helle D Kjærsgaard

Helle Palm $\varnothing$

Helle Pelant Lahrmann

Henrik Bech Pedersen

Henrik Bækstrøm

Hugo Holm

Inge Larsen

Inger Morthorst Møller

Janni Hales Pedersen

Jens Johannes Sørensen

Jens Legarth

Jens Noesgaard Jørgensen

Jens Peter Nielsen

Jens Ulrich Nielsen

Jens-Erik Zerrahn

Jesper Poulsen

John Larsen

Jos Botermans

Josefine Lindegaard

Josephine Rickert Lundberg

Juan Miguel Peralvo Vidal

Julie Elvekjær Hansen
Student, Animal Science

Technical Sales Manager, NordicBiochem Zusatsstoffe Handels

- und Produktions ges.mbH

MSc. in Parasitology, PhD student, IVS, KU

Dyrlæge, Fødevarestyrelsen

Formand, Landbrug \& Fødevarer, Svineproduktion

Vet student \& part time pig farmer, Københavns Universitetet

\& Landmand Martin Molbo

Chefforsker, SEGES Videncenter for Svineproduktion

MSc, Copenhagen University/ MSc Applied Ethology and

Animal Biology

Veterinär, Går \& Djurhälsan AB

PhD student, University of Copenhagen

Industrial PhD Student, University of Copenhagen, IPH \& MSD

Animal Health

Professor, University of Copenhagen

Cand. Agro, Erhvervsakademi Sjælland

Vet, SEGES Pig Research Centre

Head of Department, IPH, SUND, University of Copenhagen

Professor, University of Copenhagen

Group R\&D Director, DLG

Videnskabelig Assistent, KU

Scandinavian Livestock Business Development manager, Orion Pharma /DVM, MBA, Certificate Swine Health Manager

Specialkonsulent, NaturErhvervstyrelsen - GUDP

Industrial PhD Student, University of Copenhagen \& SEGES Pig Research Centre

Konsulent, Merial Norden

Afd chef, Tican Fresh Meat A/S

Direktør, Big Dutchman Skandinavien A/S

Dyrlæge, IDT Biologika

Kandidatstuderende, Veterinær medicin

Post doc., University of Copenhagen, IPH

DVM, Svinepraksis DK

CEO, European Proteinfermentationexperts AS

Global Product Manager, Chr. Hansen A/S

Professor, University of Copenhagen, IPH

Director, Innovation, SEGES Pig Research Centre

Technical sales Manager, Nordic-Baltic, EVONIK / MSc.Agric

Seniorkonsulent, SEGES Videncenter for svineproduktion

Head of division, DVFA

AgrD, Sveriges Lantbruksuniversitet

Volont $\varnothing r$, SEGES Videncenter for Svineproduktion

Studerende, ErhvervsAkademi Sjælland, Slagelse

MSc. student in Animal Sciences, University of Copenhagen

PhD student, DTU Vet 
Julie Lynegaard

Jørgen Lindahl

Jørgen M. Westergaard

Karl Johan Klit

Karl Kristian Kongsted

Karl Pedersen

Katarina Karlsson Frisch

Katarina Nielsen Dominiak

Kathrine Poll

Ken Steen Pedersen

Kimmie Kyed Lyderik

Kirsten Jensen

Kirsten Volmer Larsen

Kirstine Lindstrøm nielsen

Kjetil Johansen

Kristian Møller

Kristine Dich-Jørgensen

Lars Bagge Juul

Lars Erik Larsen

Lars Jensen

Lars Katborg

Lars Kristian Clausen

Lars Kunstmann

Lars Sangill Andersen

Laura Myhill

Lea Hübertz

Leif Meedom

Leif Vraa-Andersen

Lene juul Pedersen

Lene Kristensen

Lisbeth Shooter

Lisette Poulsen

Liza Rosenbaum Nielsen

Lola Tolstrup Leihardt

Louise Bundgaard

Louise Kruse Jensen

Louise Hägg Grønborg

Magnus Paulsson

Margit Andreasen

Maja Kobber $\varnothing$

Maria Eskildsen

Marianne Kaiser

Marie Rama Tamberg
BSc, University of Copenhagen, Animal Science

DVM cert. pig diseases, Distriktsveterinärerna/ $\varnothing$-vet

Dyrlæge, PhD ADC-Consult

PhD student, Department of Large Animal Sciences

Spesialveterinær, Kjøtt og Fjørfebransjen Landsforbund/

Veterinær

Professor, DTU Veterinærinstituttet

Djurhälsoveterinär, Gård \& Djurhälsan AB

PhD student, University of Copenhagen

Dyrlæge, Orion Pharma animal Health

Adm. direkt $\varnothing r$, specialdyrlæge, $\varnothing$-Vet $A / S$

Student, Master of Animal Science

Technical Account Manager, Elanco / DVM

Business Manager, HIPRA Danmark

Studerende, Veterinærmedicin

Dyrlæge, LVK

Head of section, DTU VET

Research assistant, Department of Veterinary Disease Biology

Dyrlæge, Fødevarestyrelsen, veterinær Nord

Professor, DTU Veterinærinstituttet

Veterinary Student

Area Manager, Phytobiotics

Faglærer, RTS | Vilvorde

DVM, Huvepharma

Nutritionist, HAMLET PROTEIN A/S

PhD student, Copenhagen University

Student, Animal Science

Dyrlæge, Huvepharma

Dyrlæge, Fødevarestyrelsen

Senior researcher, Århus University

Dyrlæge, Fødevarestyrelsen

Afdelingsleder, SEGES Videncenter for Svineproduktion

Konsulent, Danish Crown

Professor, University of Copenhagen

DVM, PhD student, IPH, University of Copenhagen

DVM, PhD, Institut for Produktionsdyr og Heste, KU-SUND

Assistant Professor, University of Copenhagen, IVS

Dyrlæge, VeterinærSyd, Fødevarestyrelsen

Djurhälsoveterinär, Gård \& Djurhälsan $A B$

Technical Manager, Danish Assoc. of the Vet Pharm Industry

Studerende, Veterinærmedicin

Lektor, Erhvervsakademi Aarhus

Studerende, KU

Studerende, Animal Science 


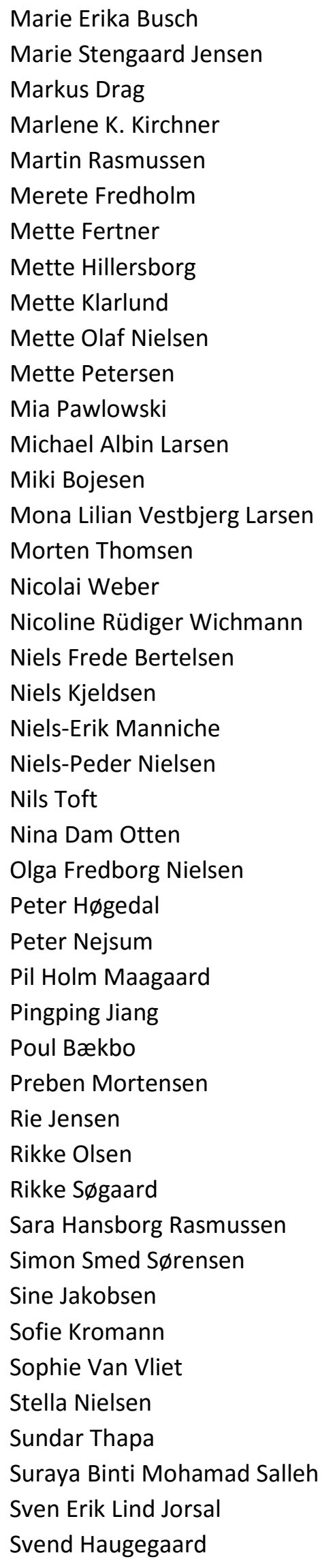

Dyrlæge, SEGES Videncenter for Svineproduktion

Cand. scient., DTU Food

PhD student, IPH KU

DVM, PhD, IPH, KU

Veterinærstuderende

Professor, KU

PhD student, Veterinærinstituttet

Dyrlæge, Ceva Animal Health

Student, Veterinary medicin

Professor MSO, University of Copenhagen

PhD student, University of Copenhagen

Dyrlæge, SEGES Videncenter for Svineproduktion

DVM, Merial Norden

Professor, University of Copenhagen

MSc in Agrobiology, Aarhus University, PhD fellow

Journalist, LandbrugsMedierne

PhD Student, University of Copenhagen, IPH

Studerende, Veterinærmedicin

DVM, ScanVet Animal Health

Senior Specialist, SEGES Videncenter for Svineproduktion

Dyrlæge, PHARManniche

Deputy Chief, SEGES Videncenter for Svineproduktion

Professor, DTU Veterinærinstituttet

Adjunkt, IPH KU SUND

Studerende, København Universitet

Dyrlæge, LVK

Associate Professor, University of Copenhagen

Dyrlæge, Fødevarestyrelsen, Veterinær Nord

Post doc., University of Copenhagen

Chef konsulent, SEGES Videncenter for Svineproduktion

DVM, Merial Norden

Cand. Scient in Animal Science, Copenhagen University

Assistant professor, Copenhagen University

Dyrlæge, Hipra Danmark

Student, Master of Animal Science

Stud. med. Vet, KU

Dyrlæge, $\varnothing$ vet

Stud.Med.Vet, KU

PhD Student, Aarhus University

Cand. Scient. Animal Science,

PhD student, IVS-SUND

University of Copenhagen

Veterinary Consultant, DTU Veterinary Institute

Vet, SEGES Pig Research Centre 


\section{Søren Sloth}

Thea Kirkebæk Larsen

Thomas Sønderby Bruun

Thomas Thymann

Tina Birk Jensen

Trine Nyborg Vestergaard

Uffe Christian Braae

Vibe $D$ Andersen

Vibe Pedersen Lund

Vivi Aarestrup Moustsen
Svinerådgiver, LandboNord

Cand.scient i agrobiologi, Baltic Control

Senior Specialist, SEGES Pig Research Centre

Assoc. Prof., University of Copenhagen

Veterinarian, Danish Veterinary and Food Administration

Dyrlæge, Fødevarestyrelsen, Veterinær Nord

PhD student, University of Copenhagen

PhD student, DTU Food

Research Assistant, University of Copenhagen

Senior Scientist, SEGES Pig Research Centre 
Key Lecture: Benefits of linking universities and the Danish pig industry from the industry's point of view

By Jens Ulrich Nielsen, Director, Innovation, SEGES Pig Research Centre 


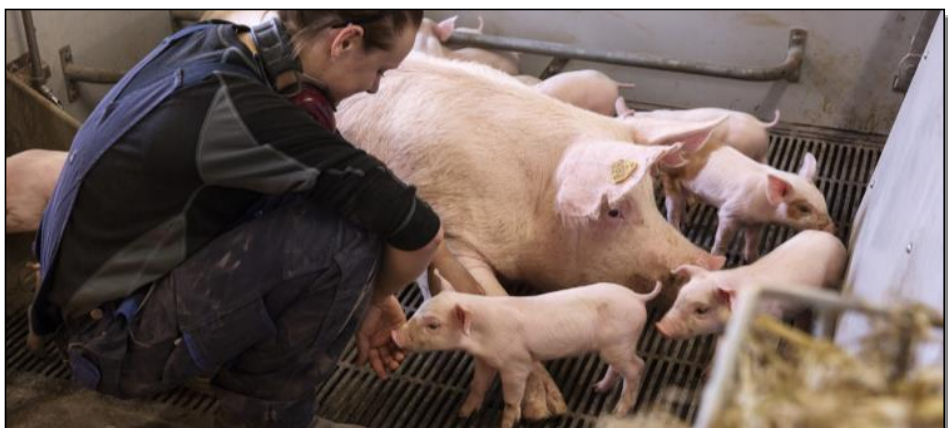

BENEFITS OF LINKING UNIVERSITIES AND THE

DANISH PIG INDUSTRY - FROM THE INDUSTRY'S

POINT OF VIEW

SEGES Pig Research Centre

Jens Ulrich Nielsen, Director, Innovation

DanAvi

OO SEGES

\section{PRODUCTION OF PIGS IN DENMARK}

Million pigs

35

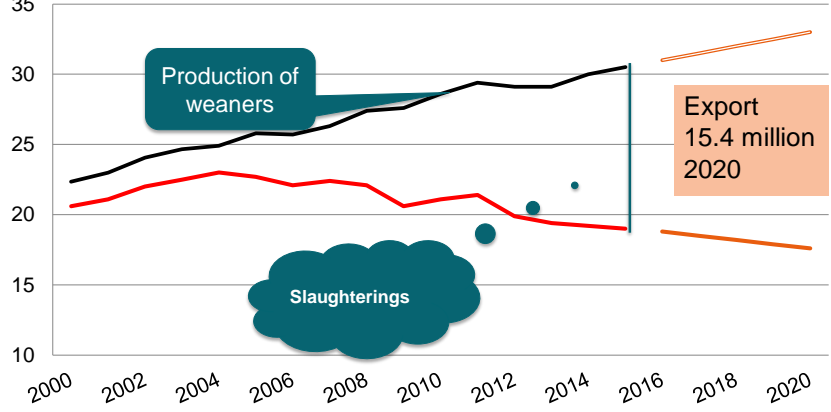

Danish pork exports

THE DANISH STANDARD:

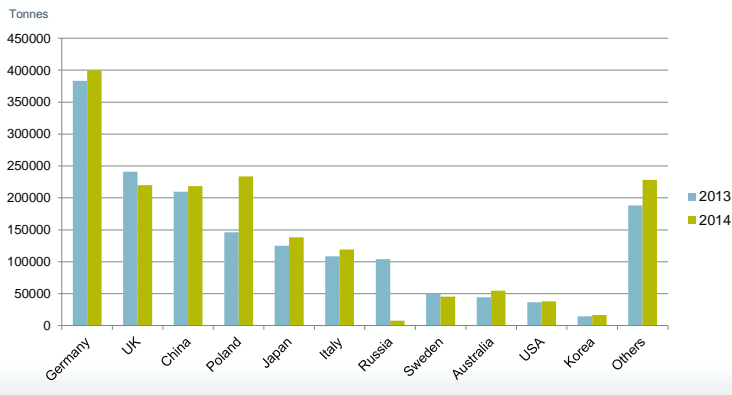



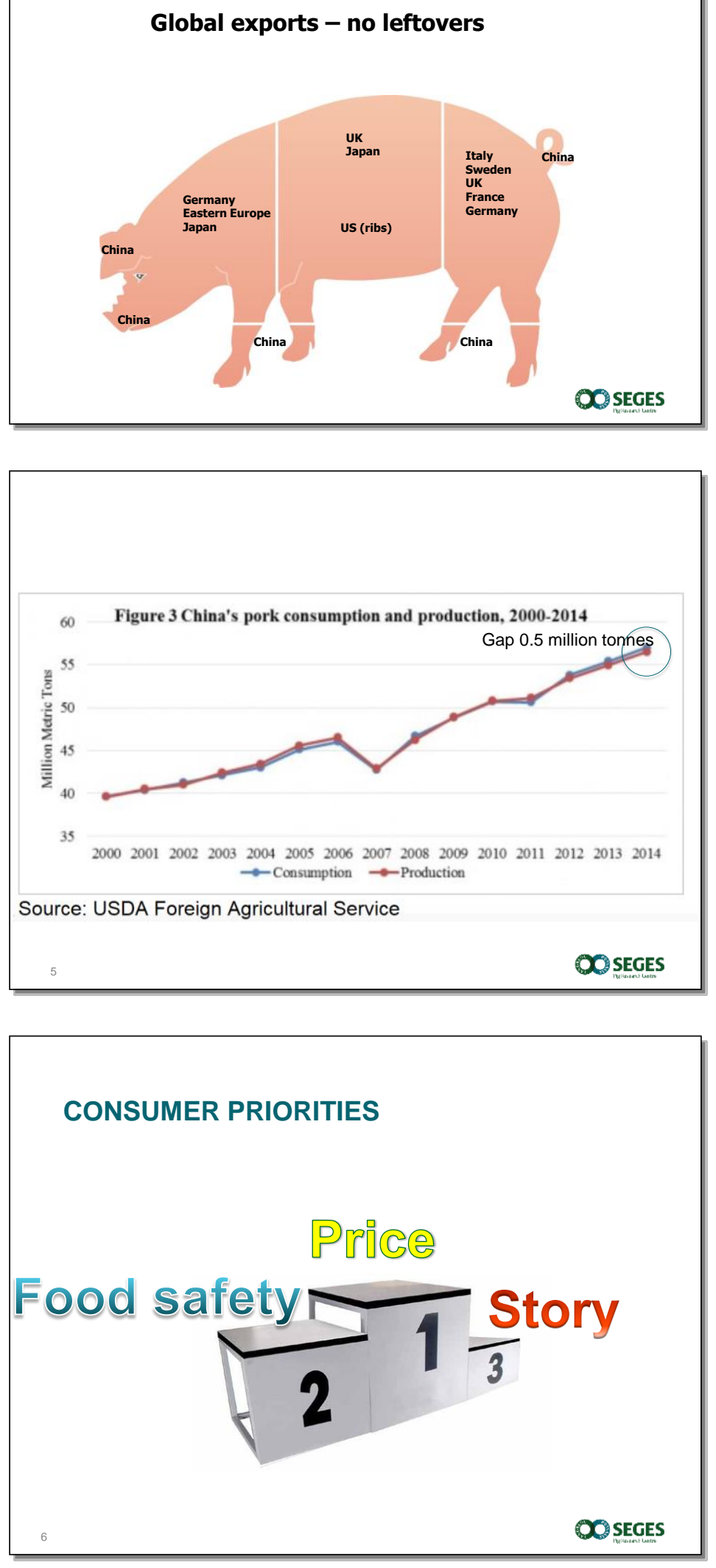


\section{COST PER KG CARCASS 2014}

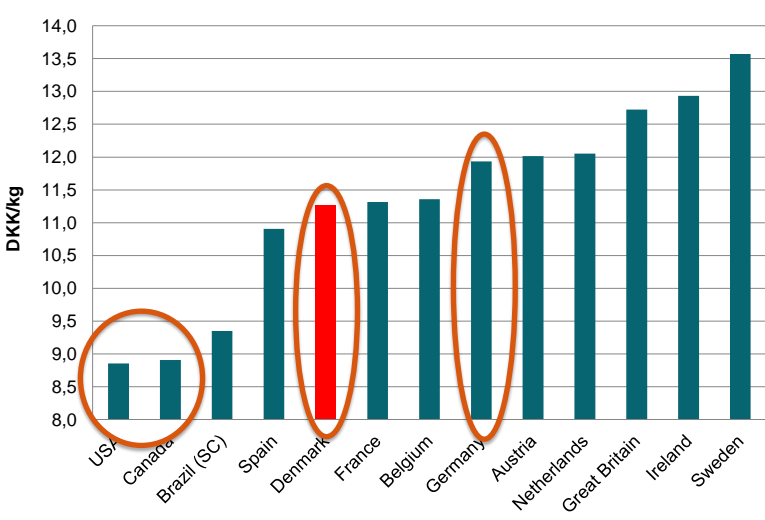

O SEGES

\section{NEW PRODUCTION METHODS}

\section{BASIS OF ADDED VALUE IN THE FUTURE}

- Digitalization of the entire value chain

- Data/Realtime data as the basis of documentation, production monitoring, decision support, benchmarking

- Emission-based environment and climate production

- Biotechnology (biogas, ethanol, new protein sources etc.)

- Cost-efficient environmental technology

- Production concepts adapted to pig producers' conditions and to the future structure
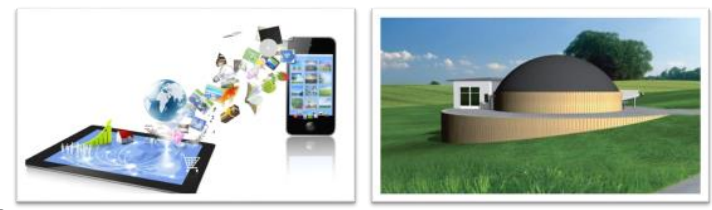

\section{NEW URGENT NEEDS FOR RESEARCH}

- Big data

- Data-driven innovation

- Internet of things in production technology

- Reduction in use of antibiotic and zinc 

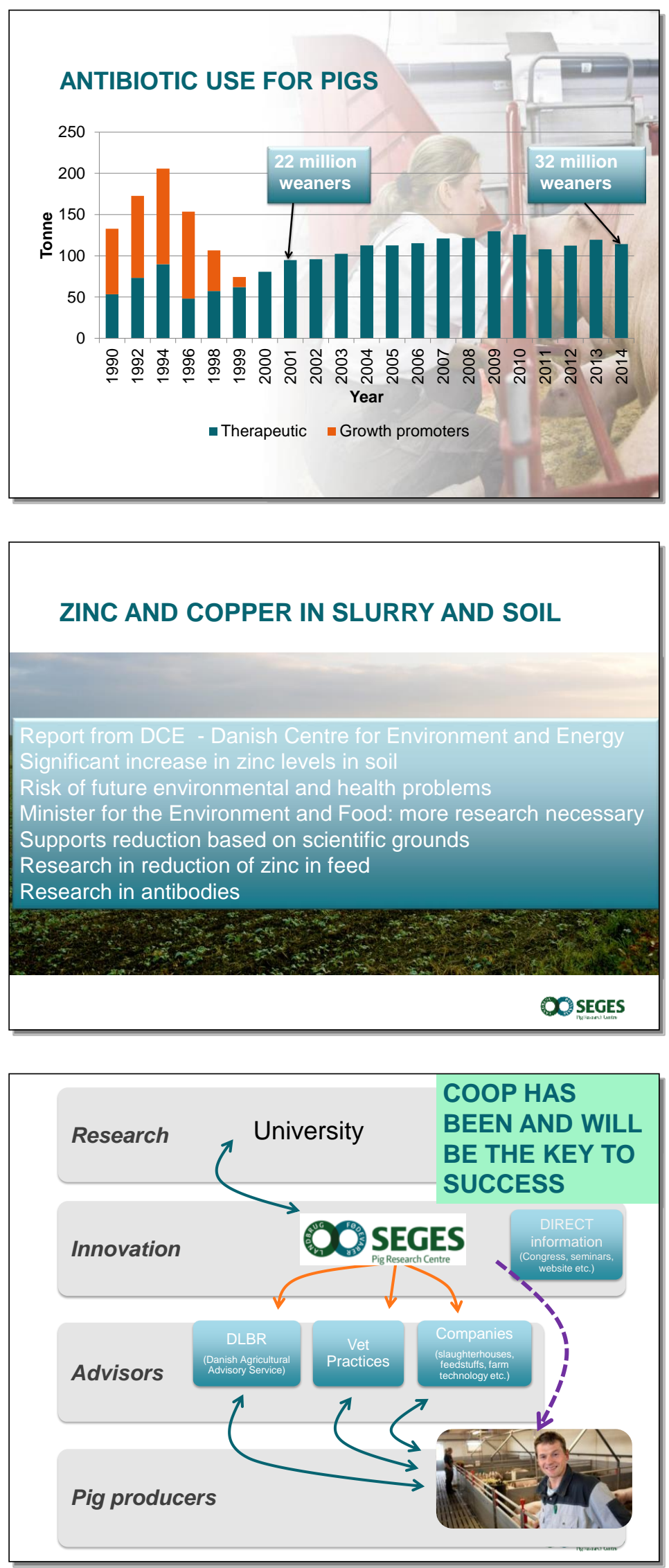


\section{DANISH PIG RESEARCH CENTRE}

- Financed by Danish pig farmers

- 160 employees

- Responsible for research and development

programmes and knowledge transfer to the Danish pig industry

- Support the development of a responsible and

economically sustainable pig industry with the highest

possible level of welfare and a minimum impact on the environment

- Trials for 15 million Euro annually

- Operate on 200 commercial farms

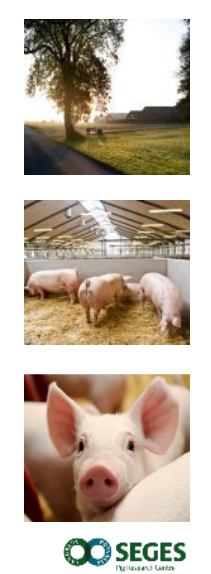

OOSEGES

\section{STRONGHOLDS IN COOPERATION WITH THE UNIVERSITIES}

- Ensure that the industry benefits from research

- More relevant pig research

- Involvement of central qualifications

- Improve credibility and validation of SEGES PRC's work

- Access to more funds

- Knowledge transfer to the industry

- Supplementary training of employees

- Recruitment of new employees

- Mutual uality assurance

- Most recent knowledge included in education

\section{MANY CHALLENGES - LOTS OF}

RESEARCH

WE ARE LOOKING FOR ANSWERS AND SOLUTIONS, NOT COSTS

sows with gastric ulcers

\section{Routine tail docking \\ Thank you \\ Environmental impact \\ MRSA}

Antibiotic use

High sow mortality rates 
Session 1: Growing Pigs 
PCV2 infection dynamics:

Diagnostics, between-batch consistency and correlation to productivity parameters

By Gitte Blach Nielsen, Industrial PhD student, Department of Large Animal Sciences, University of Copenhagen \& MSD Animal Health 


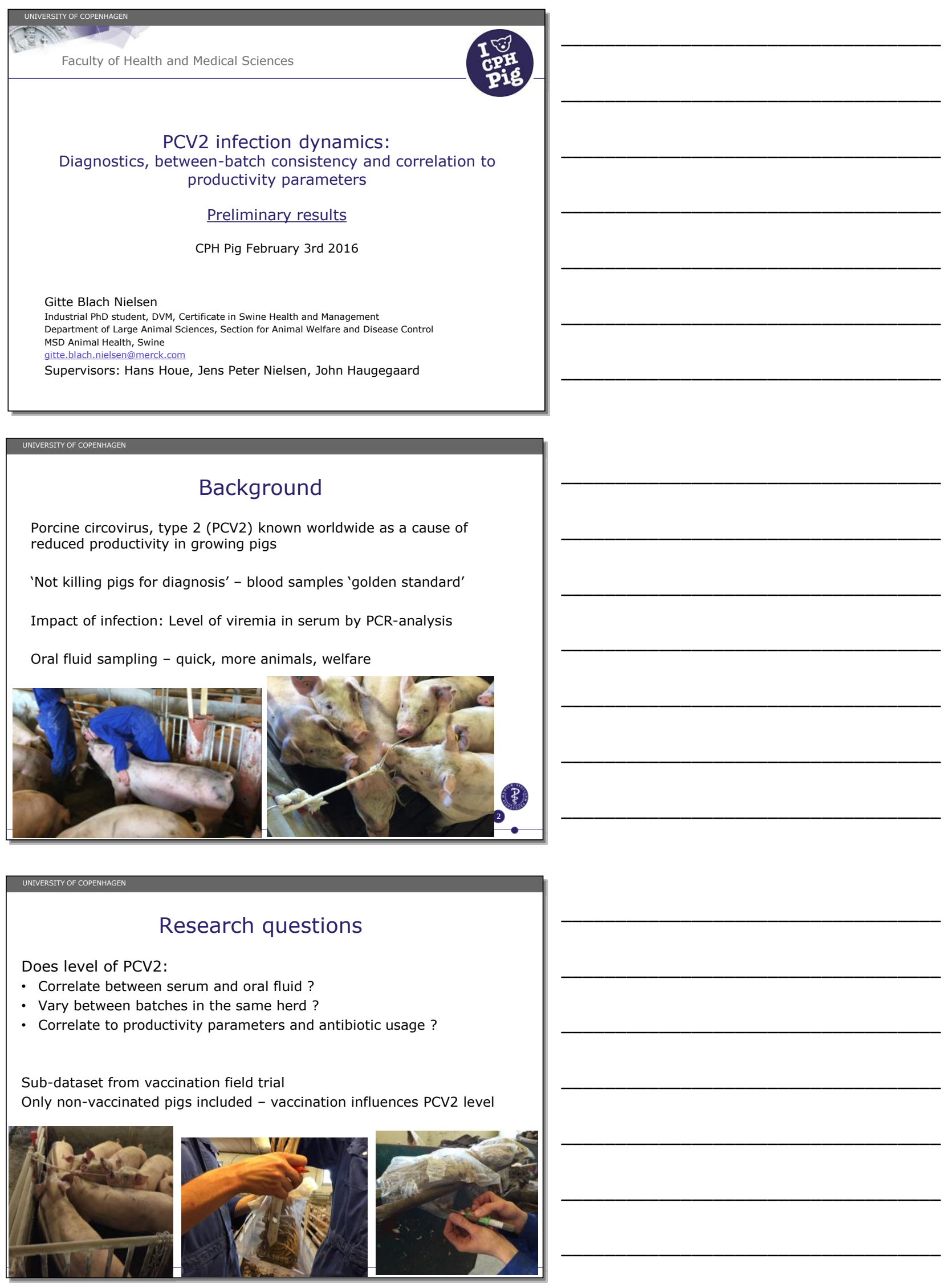




\section{Study design}

1 finishing herd 'Blue SPF' - highest health status

14 batches included (arriving 2 weeks apart), 2-5 pens sampled in each:

4 blood samples per pen -> 1 pool for PCV2-PCR-analysis

2 cotton ropes for oral fluid collection per pen -> 1 pool for PCV2-PCR-analyse

PCV2-PCR at DTU-Vet. -> 'viral copies per ml sample' on a log(10)-scale

Timeline

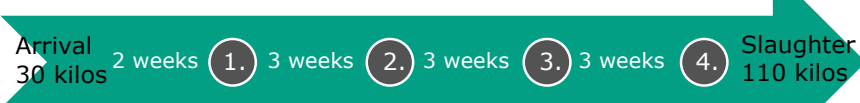

The same 4 pigs bled at consecutive sampling time points

- unless removal due to death or disease had occurred

8 MSD

4

\section{Results}

Totally, 65 pens sampled 4 times $=260$ serum/oral fluid pairs

Results are not published yet and therefore omitted

\begin{tabular}{l} 
DIagnOStICS \\
- serum and oral fluid correlations \\
Results are not published yet and therefore omitted \\
\hline MSD
\end{tabular}



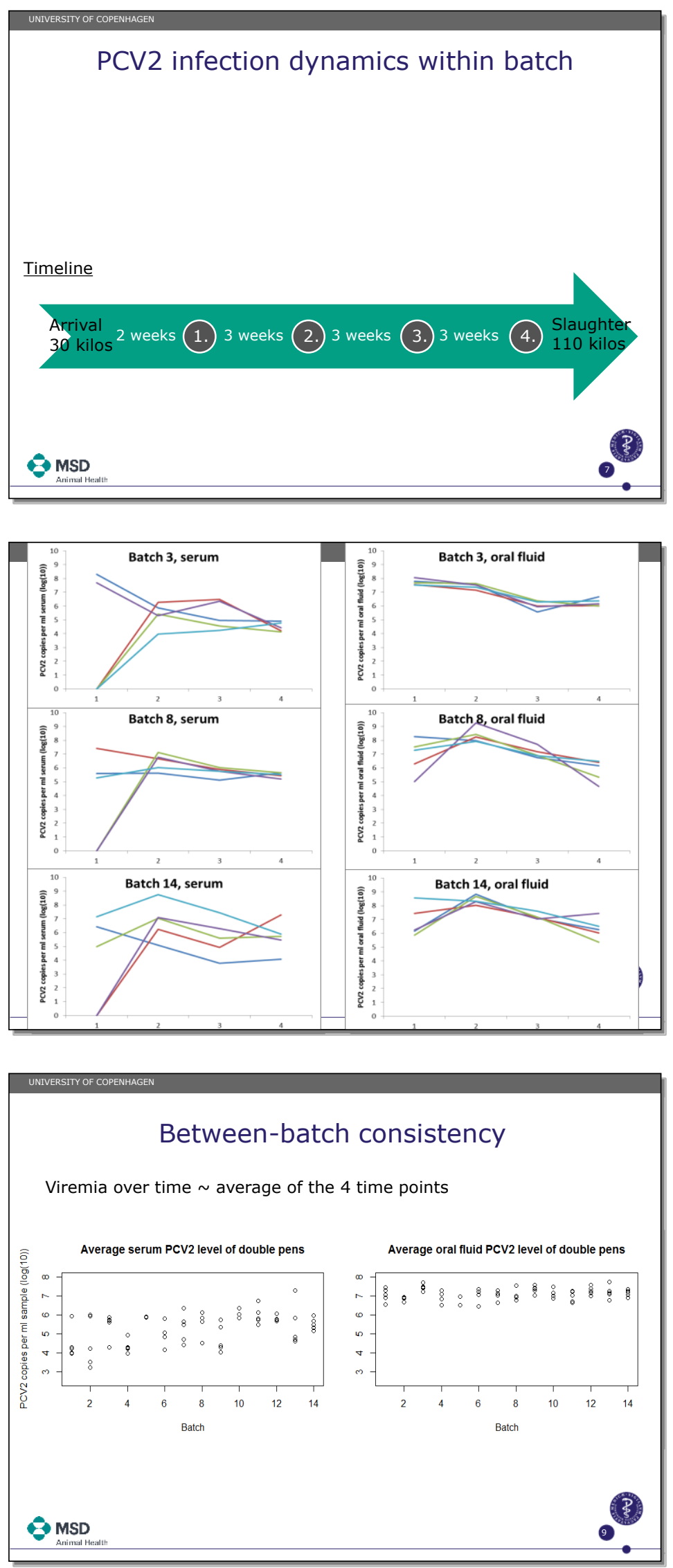


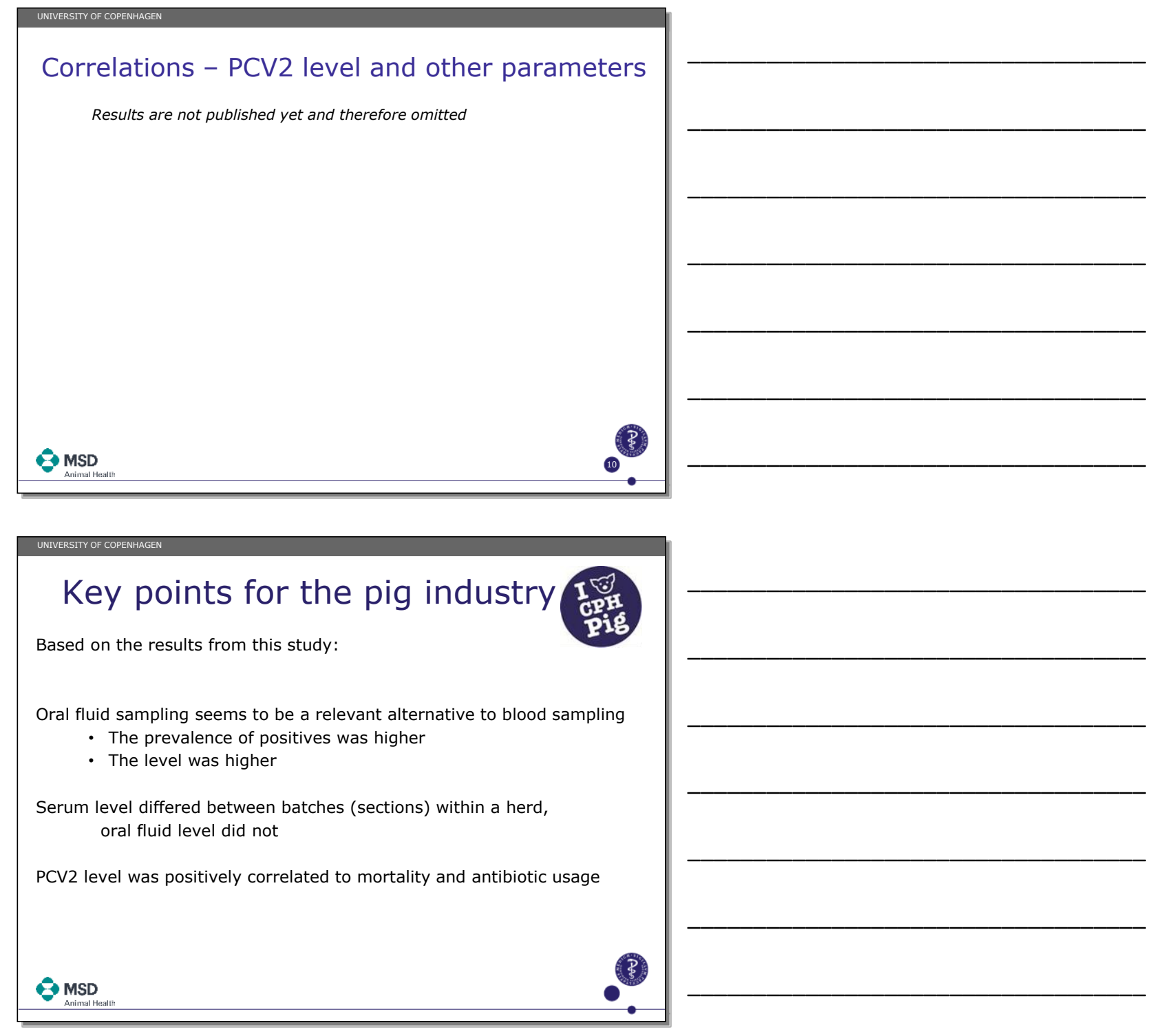


A multivariate dynamic linear model for early warnings of diarrhea and pen fouling in slaughter pigs

By Dan B. Jensen, PhD student, Department of Large Animal Sciences, University of Copenhagen 


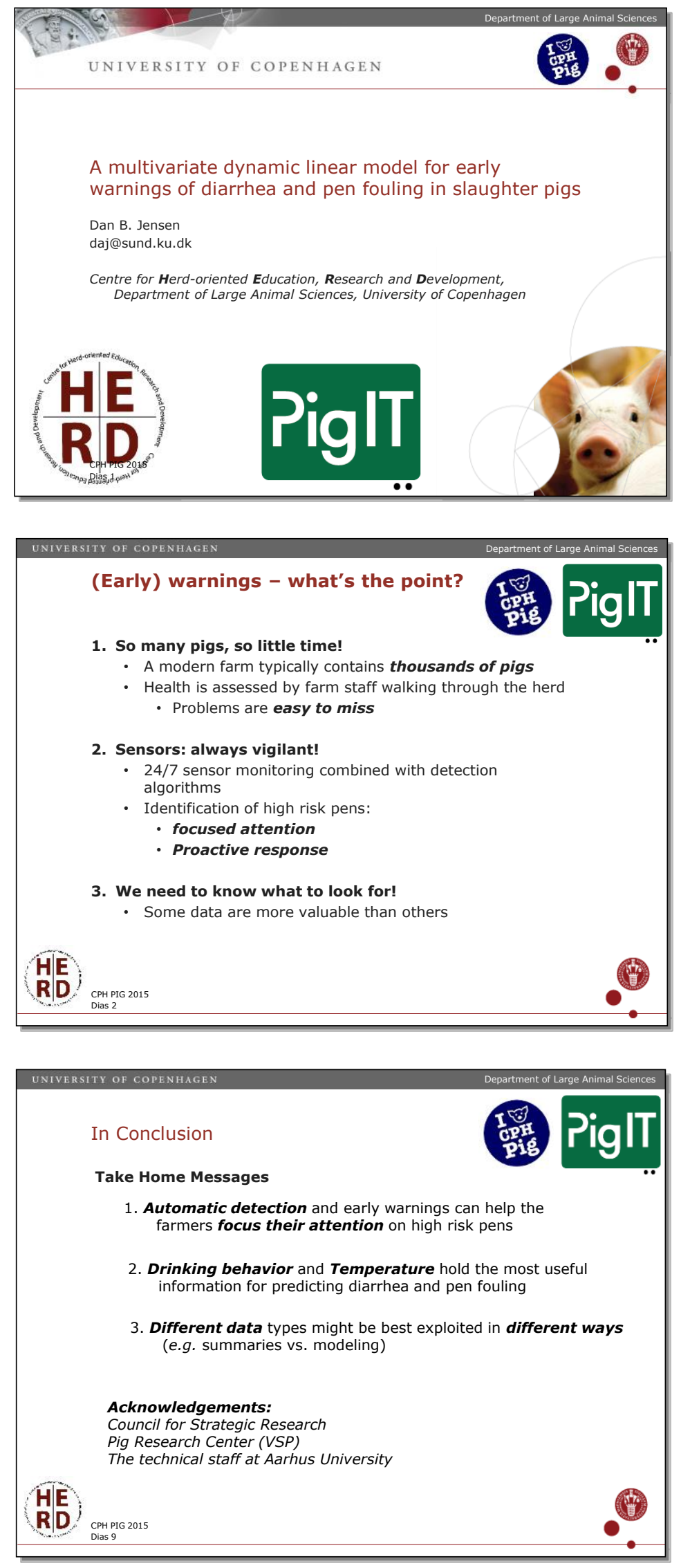




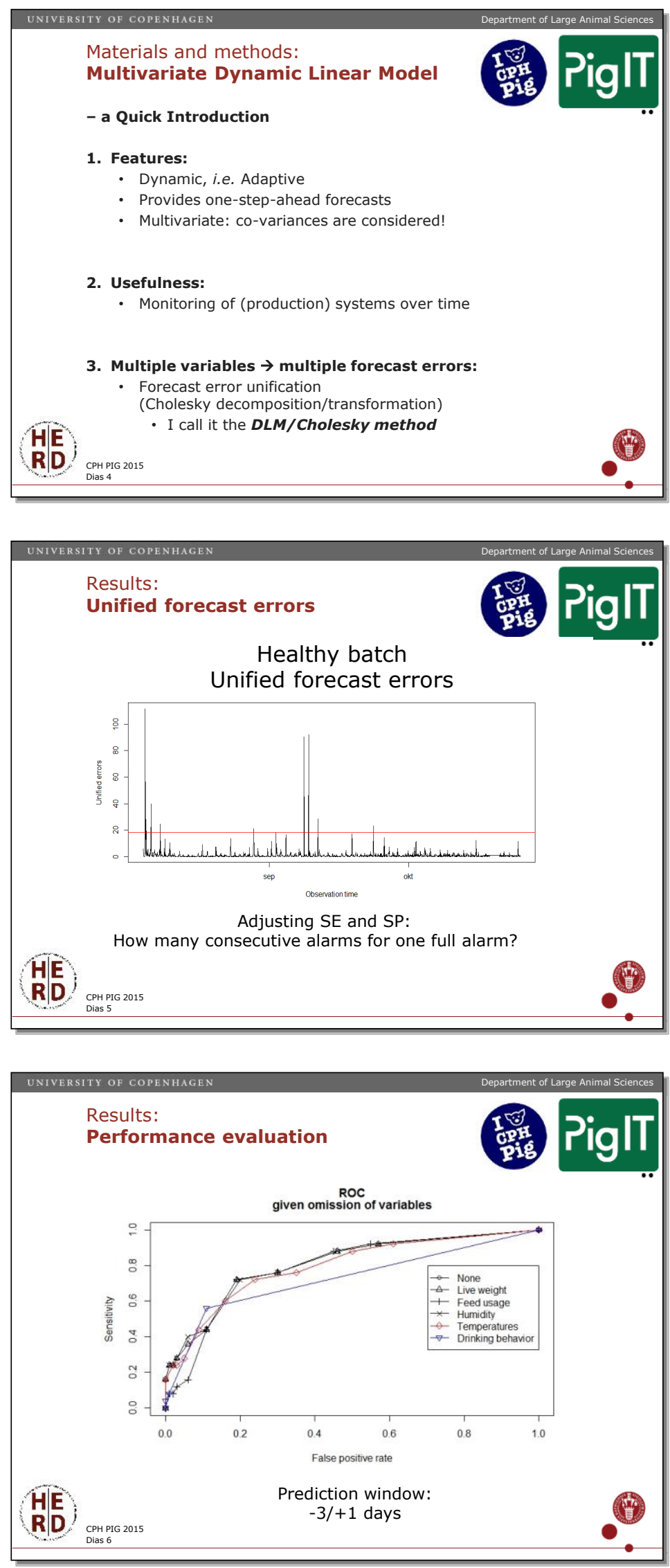




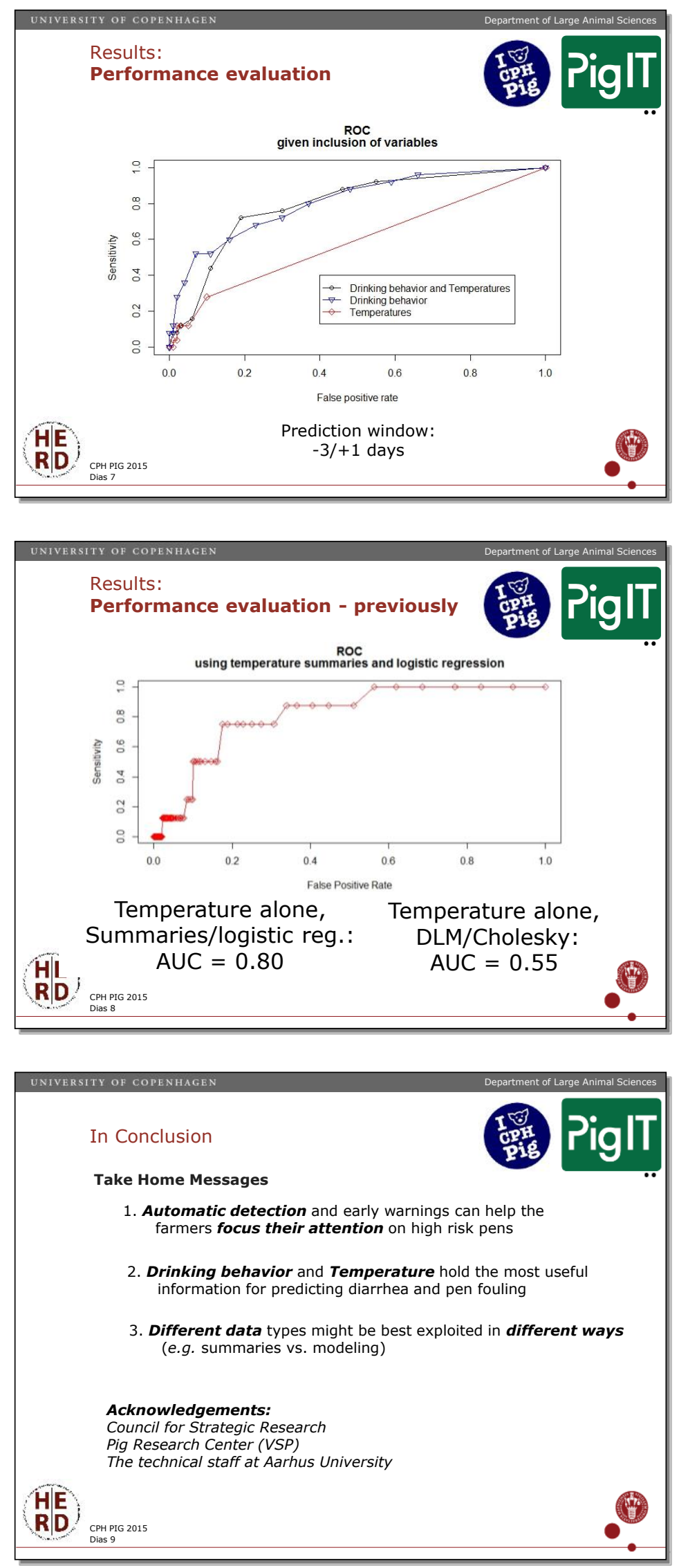


Osteomyelitis in Danish slaugther pigs

By Louise Kruse Jensen, Assistant Professor, Department of Veterinary Disease Biology, University of Copenhagen 


\section{Osteomyelitis in Danish slaugther pigs}

Louise Kruse Jensen, DVM, PhD

Assistant professor in Veterinary Pathology

Louise-k@sund.ku.dk

Osteomyelitis is a common finding in Danish slaughter pigs.

- Welfare problem for the indiviual pig.

- Economic problem

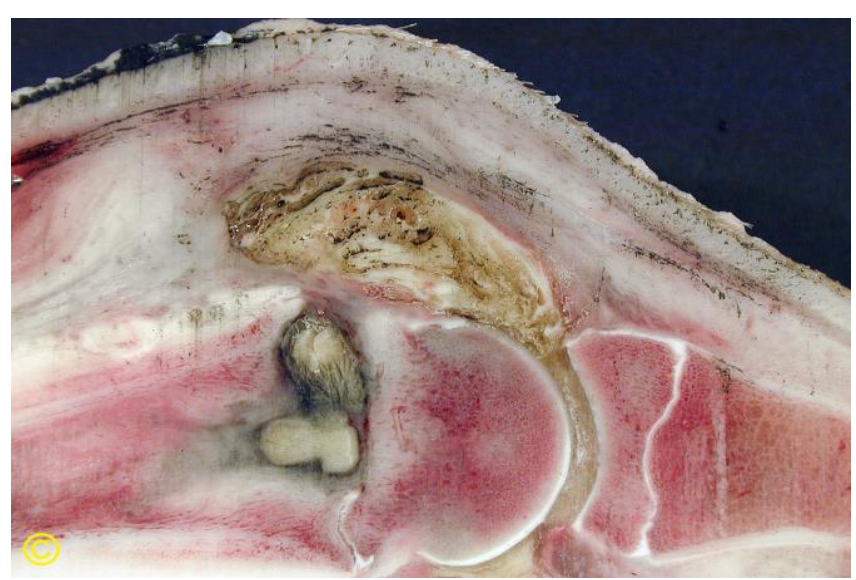

Inflammation of the bone and bone marrow = osteomyelitis 


\section{Pathogenesis}

Systemic haematogenous

- Metaphysis - long bones

- Vertebrae

- Ribs

- Local lymphatic/haematogenous

- Vertebrae, caudally from os sacrum

$$
\text { - Tail biting }
$$

- Traumatic

- Shoulder ulcerations

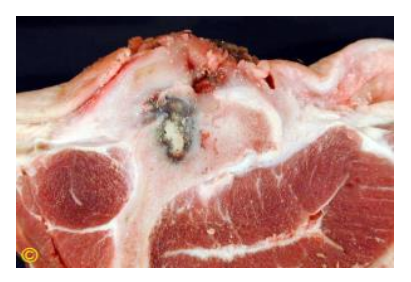

Concomitant tail biting and vertebral osteomyelitis in and caudally from os sacrum = local rejection of the pelvic bloc
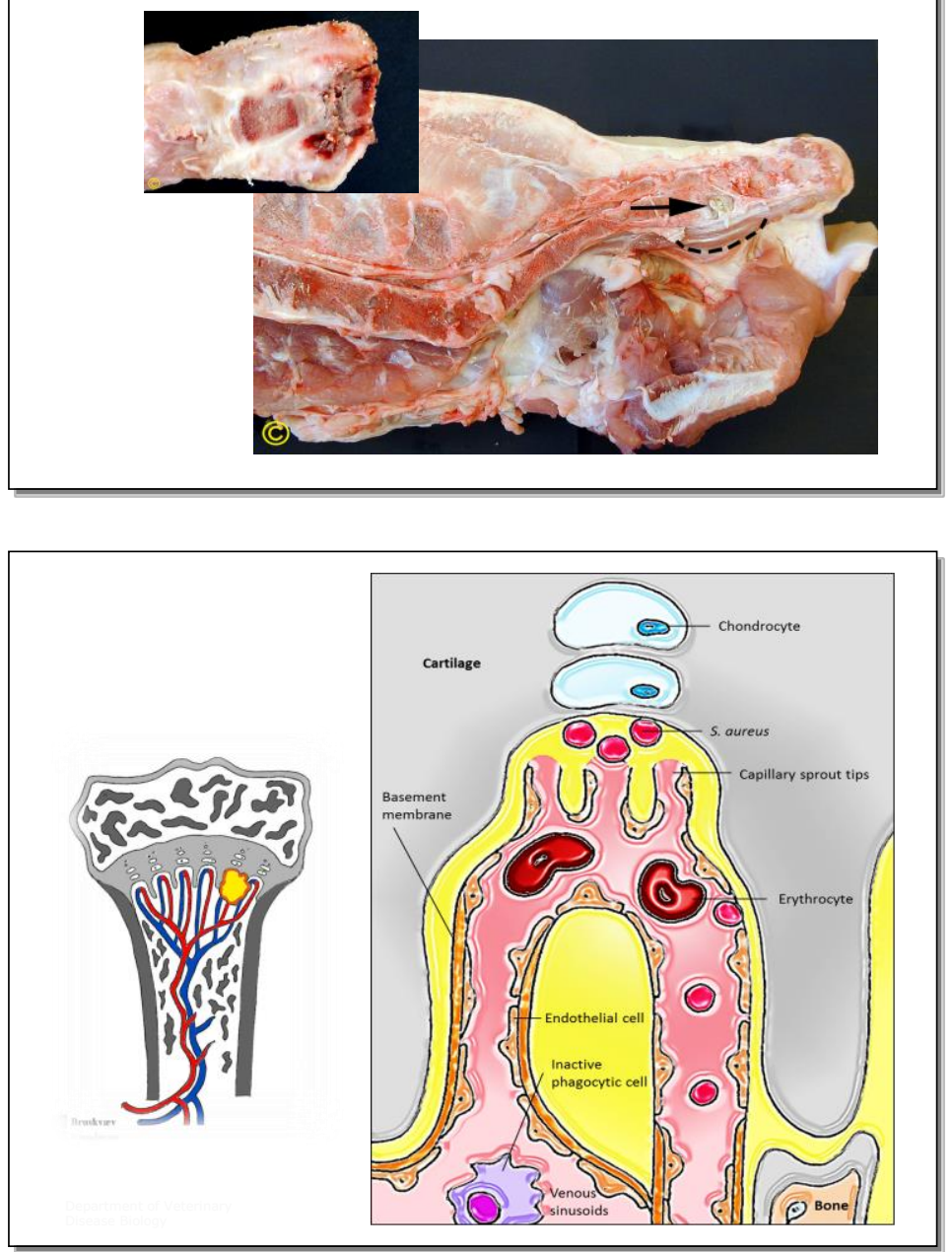


\section{Sequelae of osteomyelitis}

- Pathological fracture

- Arthritis

- Soft tissue/muscular abscess

- Sequestra formation

- Retained grow

- Malformations of the bone

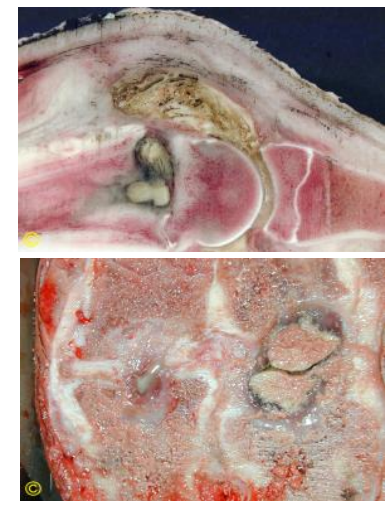

Incidence of osteomyelitis

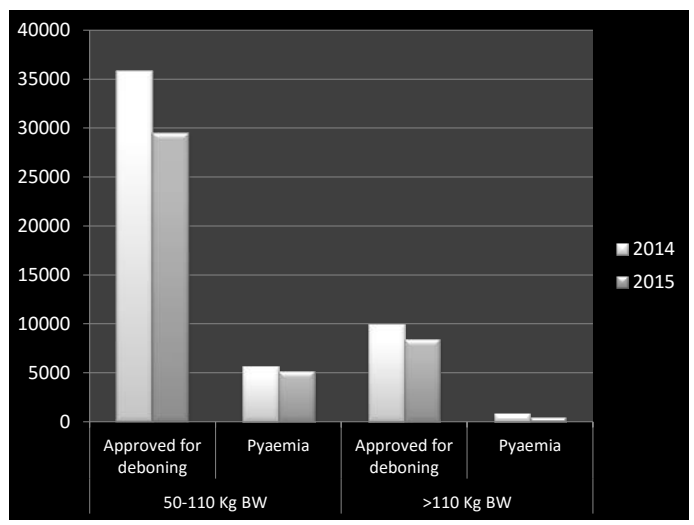

Why is these data a problem?

- Economic

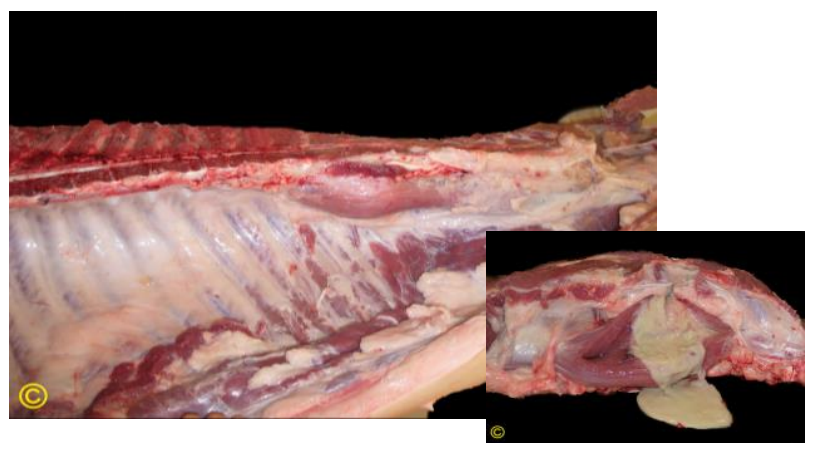




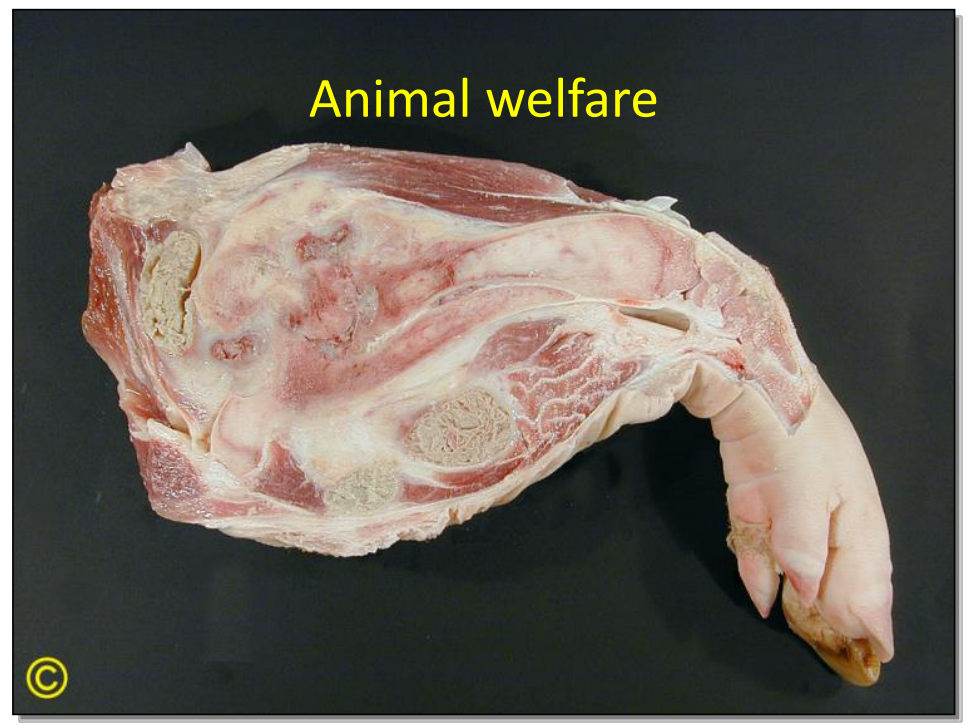

\section{My research}

PhD title: "Development, charaterization and application of a porcine model for haematogenous osteomyelitis in children"
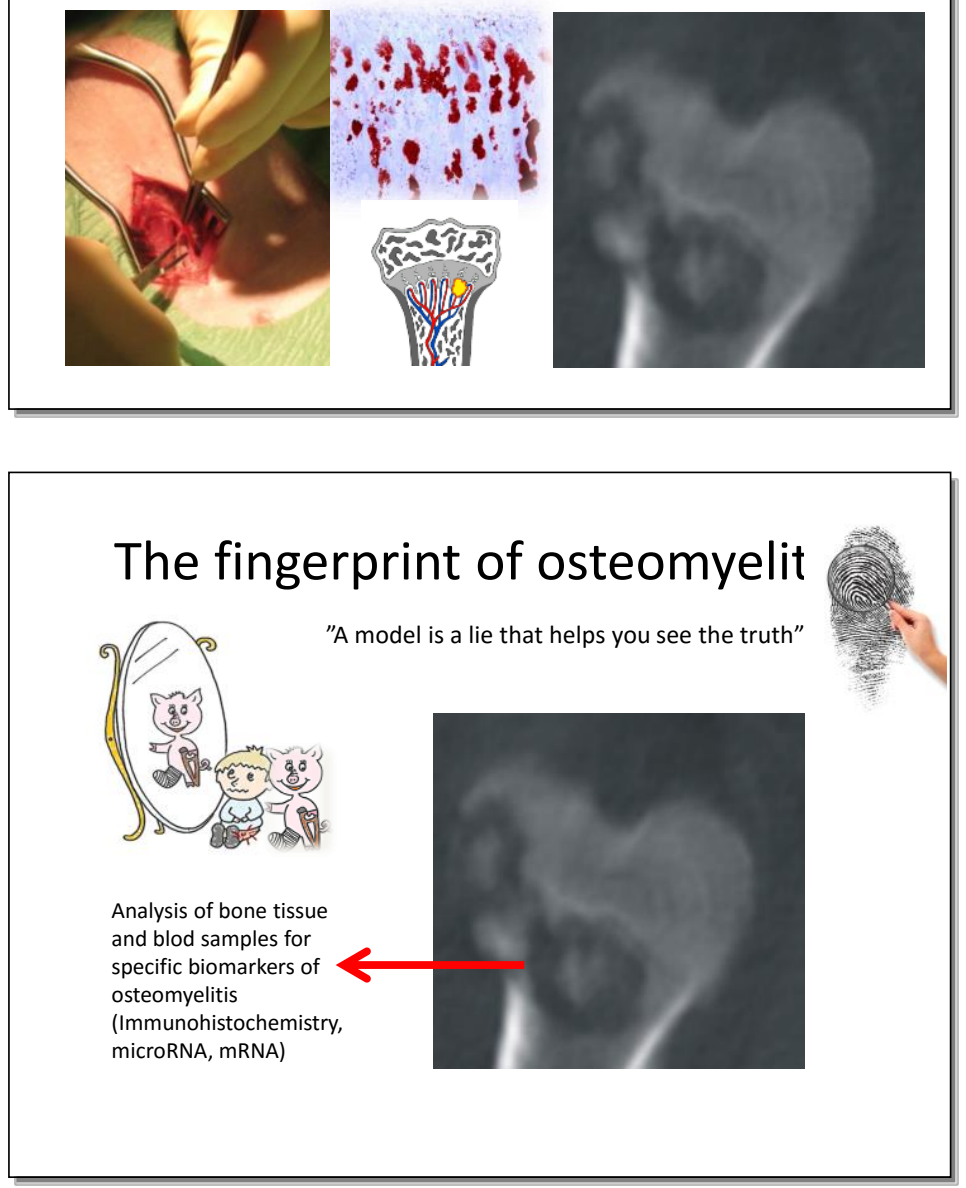
Benefit of my research

for the Danish pig industry

Finding of biomarkers for osteomyelitis can result in a futher diagnostic tool

Increased focus on individual welfare 
Monitoring growth in finishers by weighing selected groups of pigs By Anna Helena Stygar, Post doc., Department of Large Animal Sciences, University of Copenhagen 

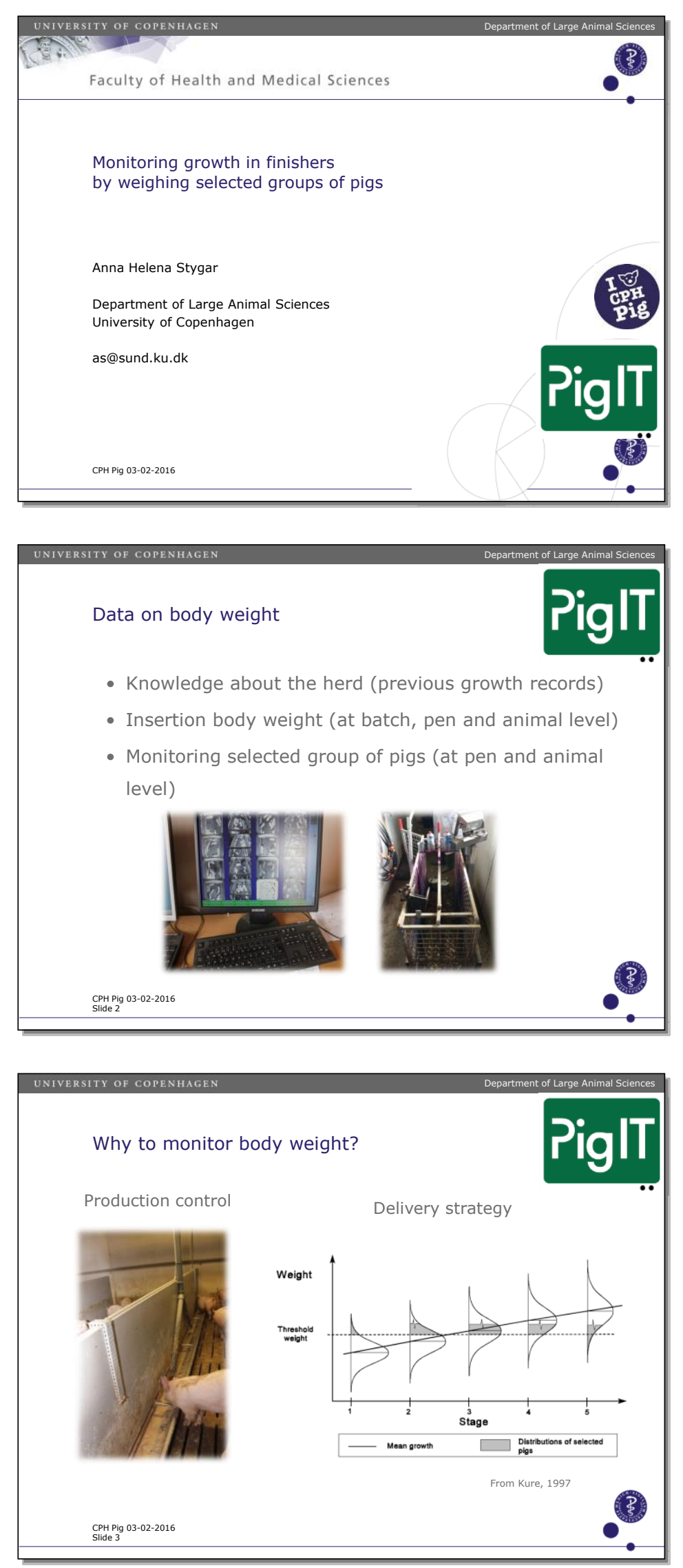


UNIVERSITY OF COPENHAGEN
Objectives of this study
- Develop a monitoring and decision support tool
- Marketing decisions (forecasting number of pigs
above a body weight threshold)
Quantify the value of information in finishers (including
or excluding the information on body weight)
cril Pig 03-02-2016
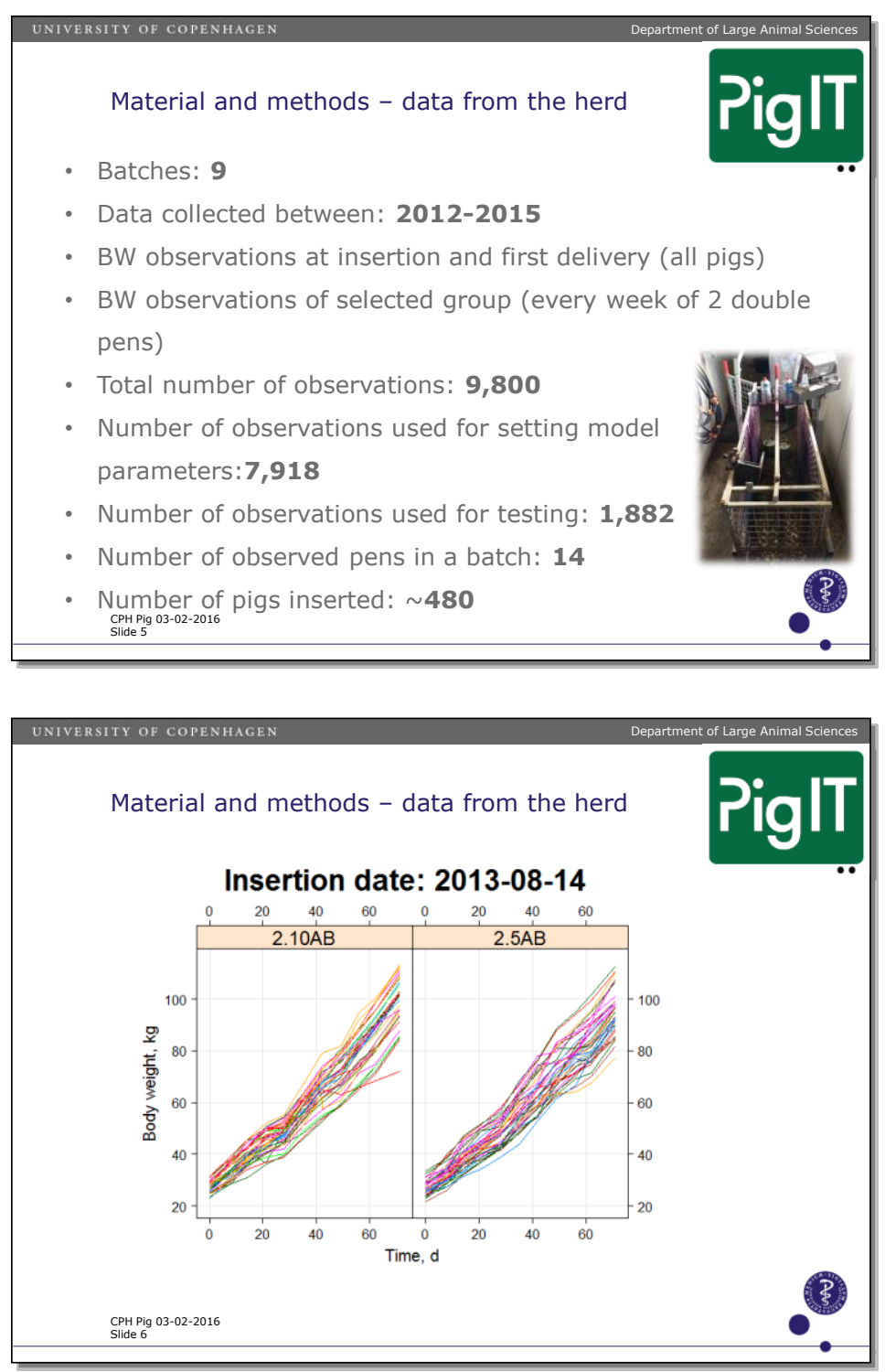

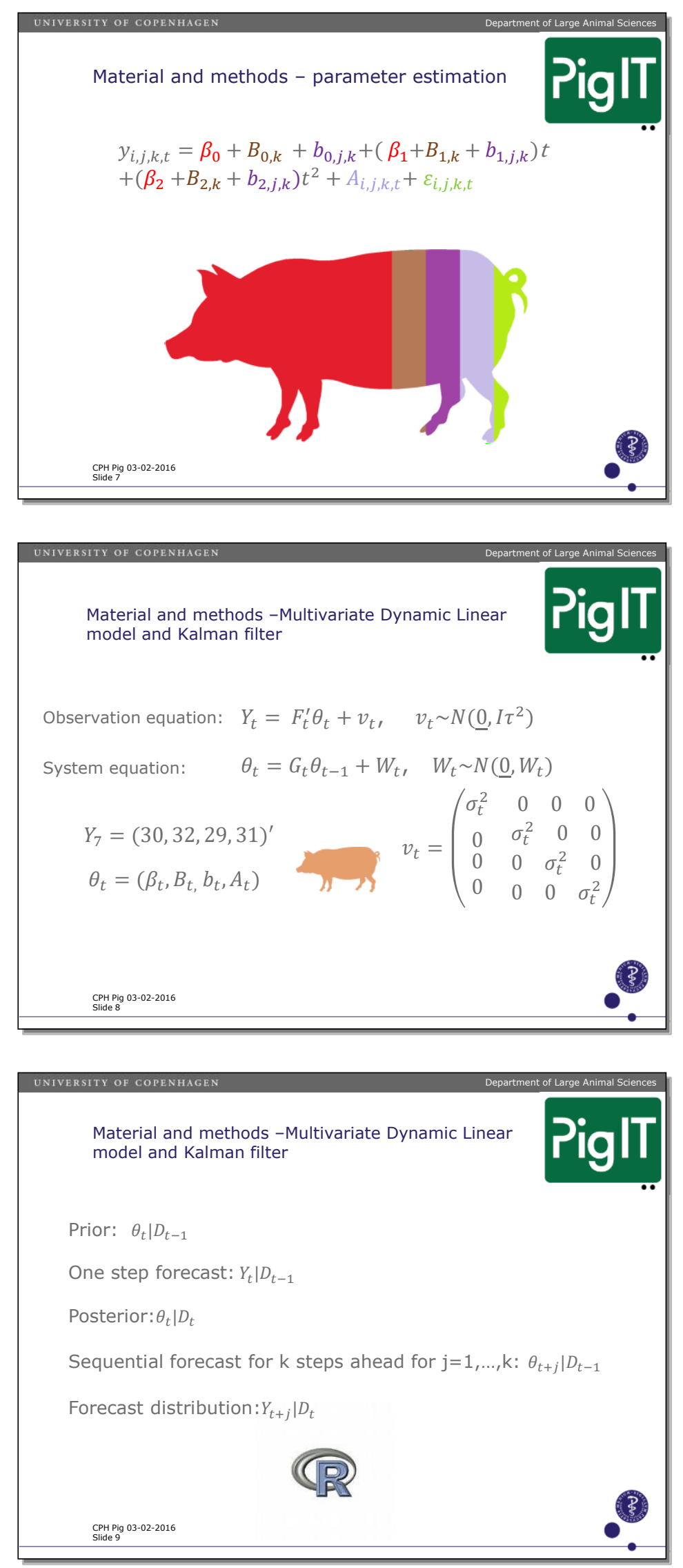

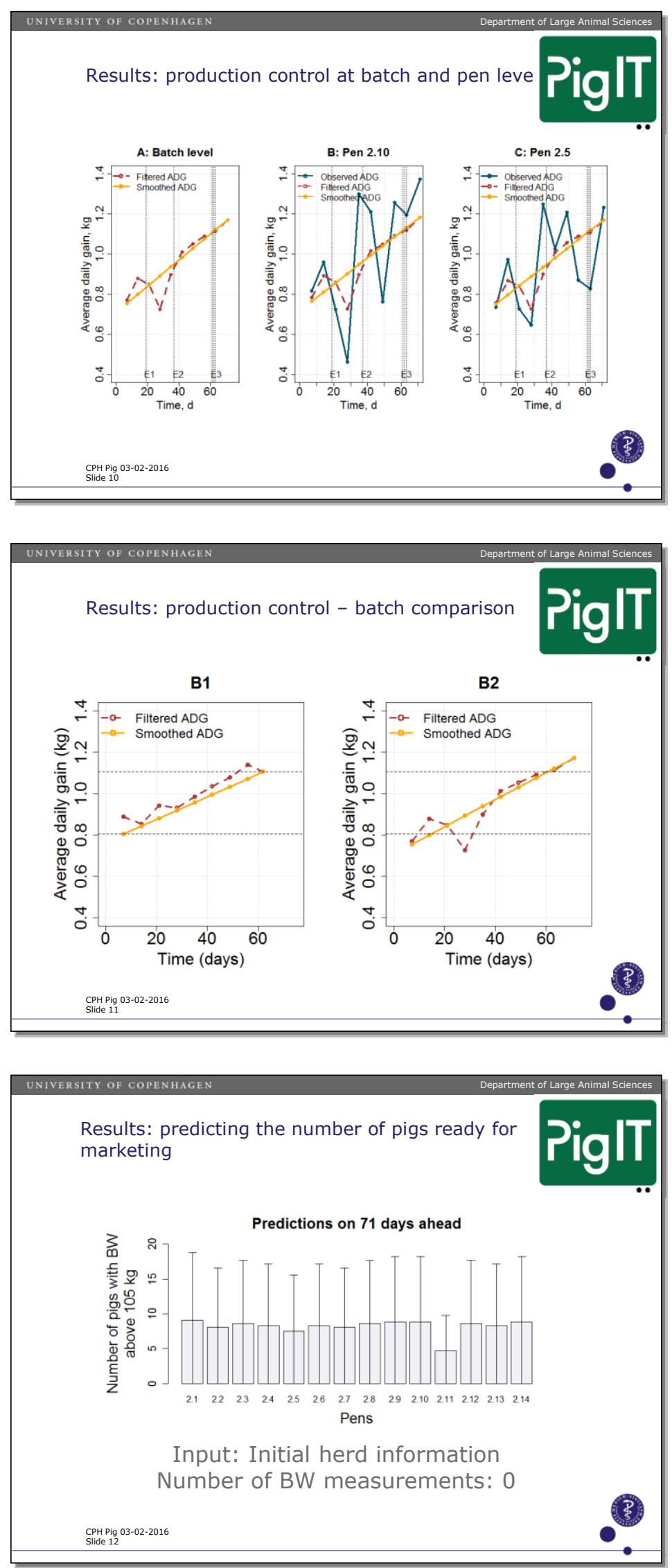


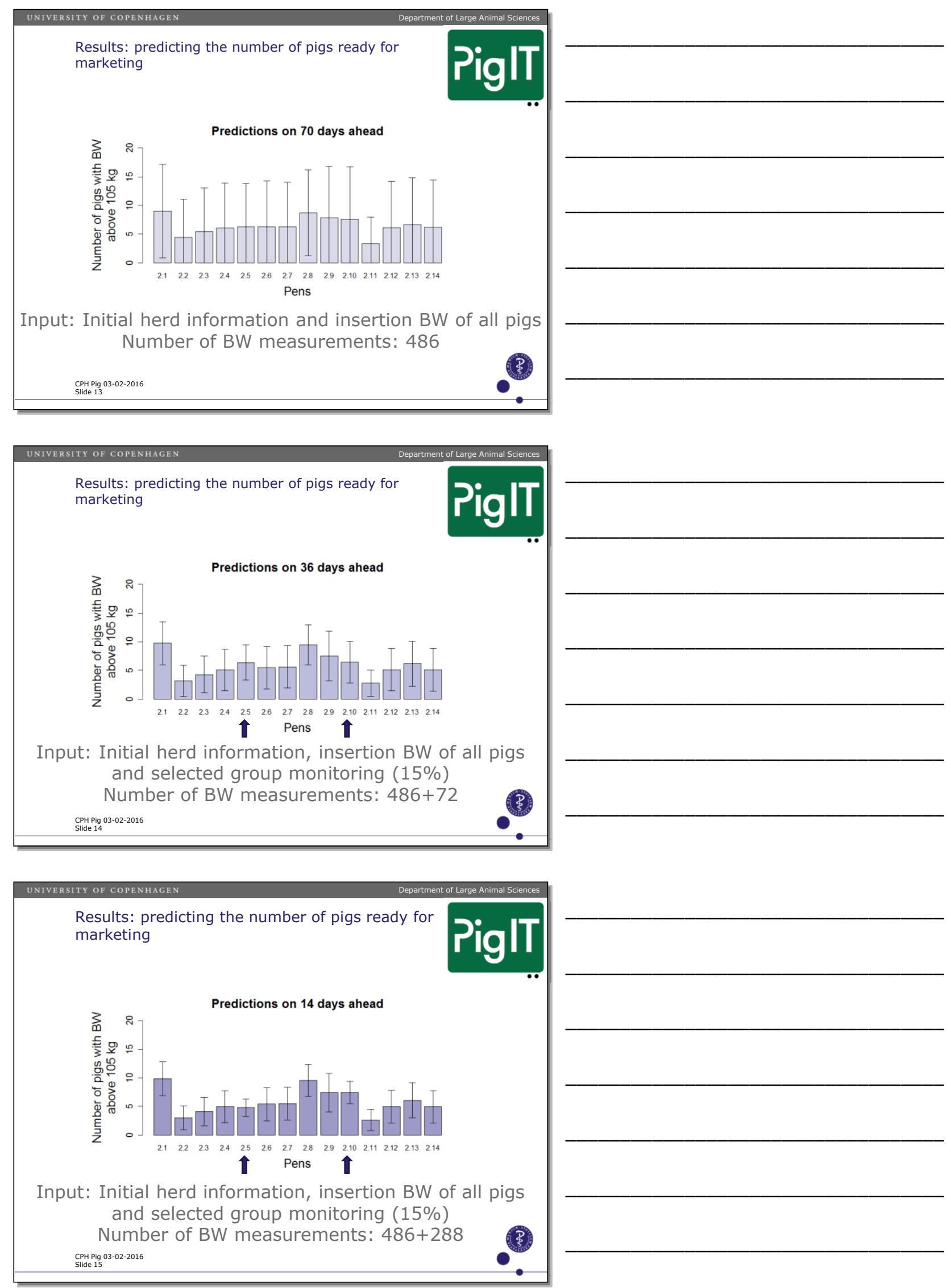


Results: predicting the number of pigs ready for marketing

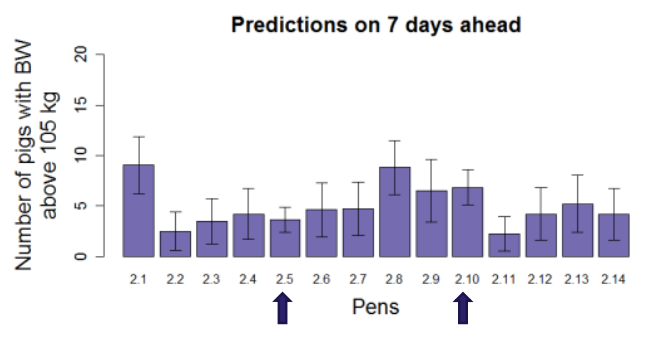

Input: Initial herd information, insertion BW of all pigs and selected group monitoring (15\%)

Number of BW measurements: $\sim 486+648$ CPH Pig 03-02-2016
Slide 16
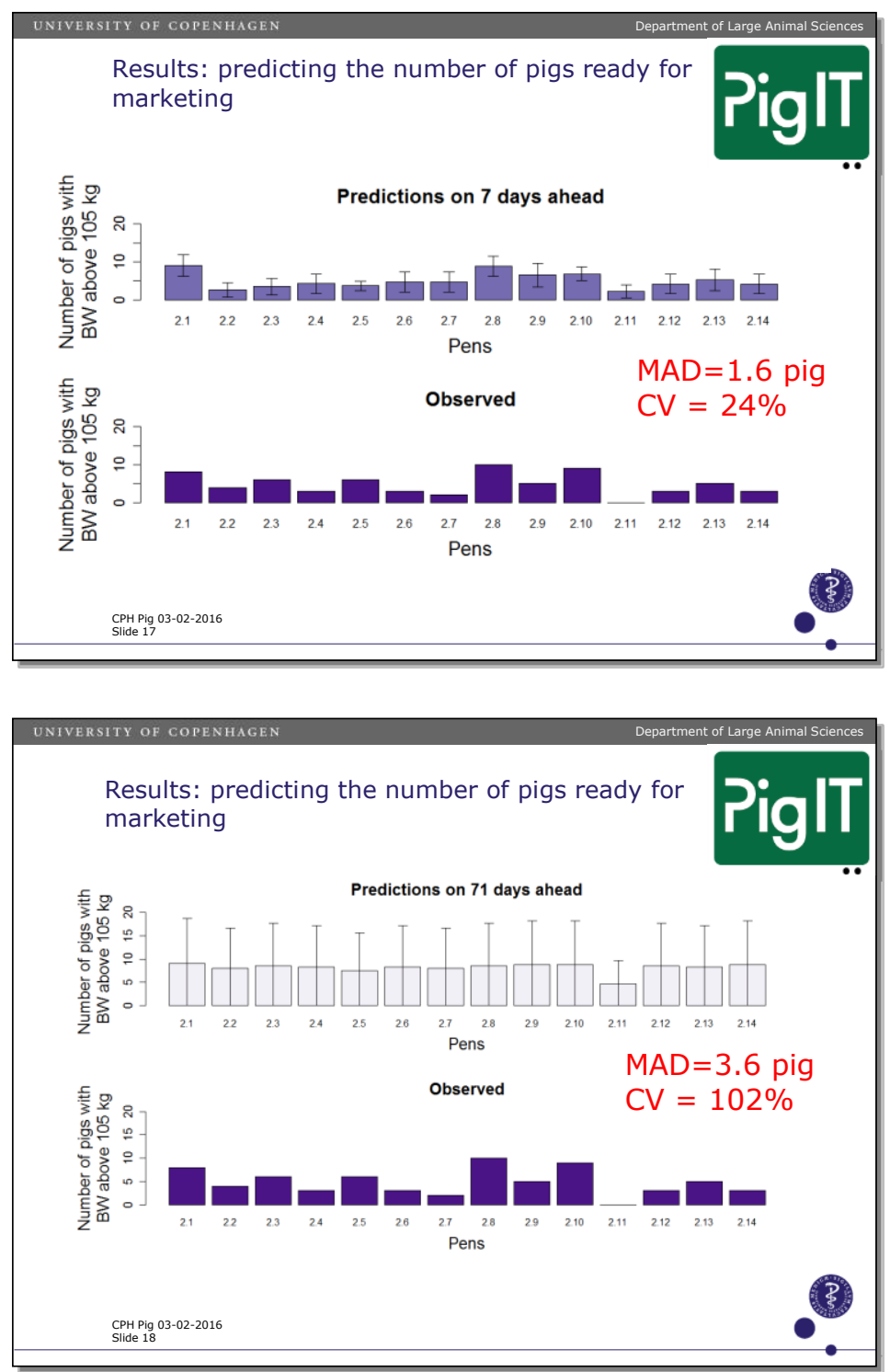

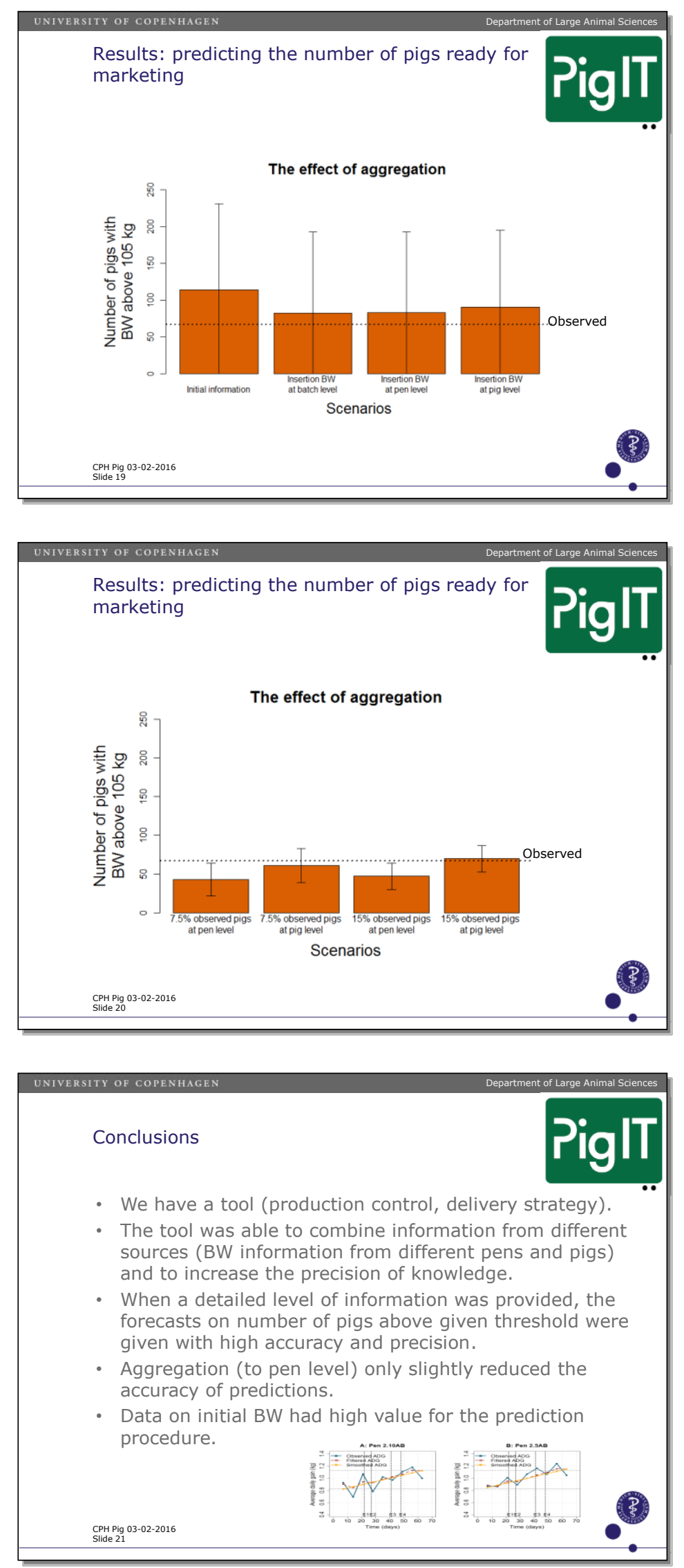

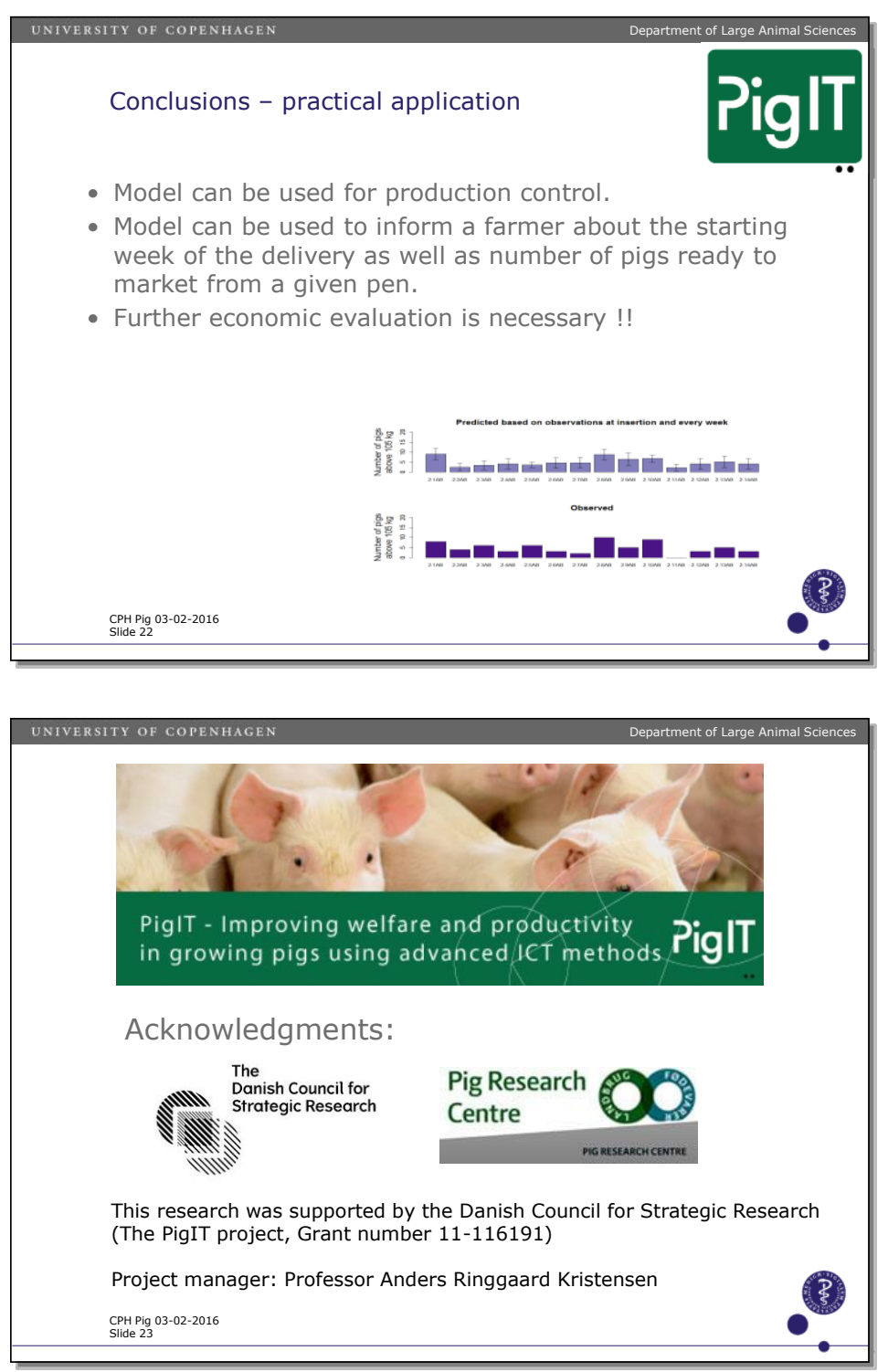
Session 2: Sows and Piglets 


\section{Monitoring PRRS using laboratory data \\ By Ana Carolina Antunes, PhD student, DTU National Veterinary Institute}



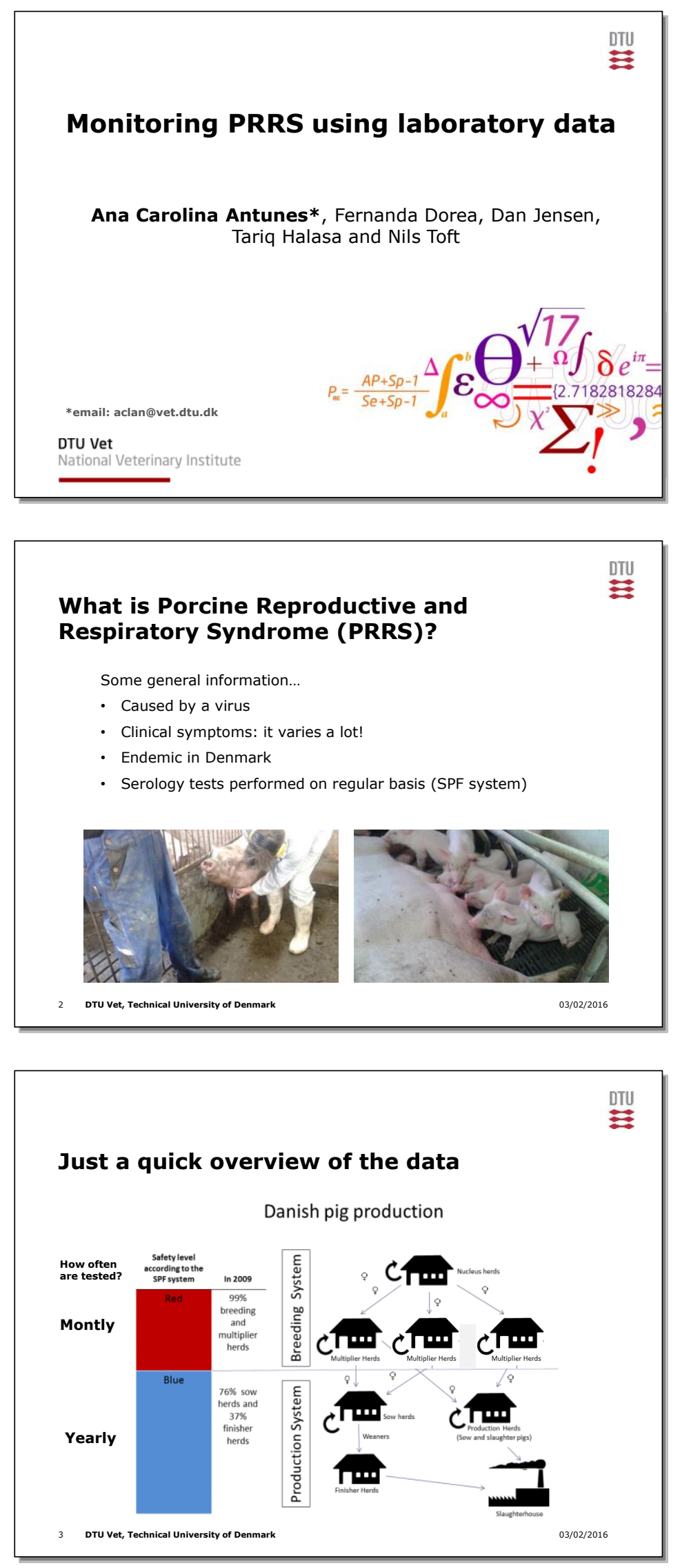

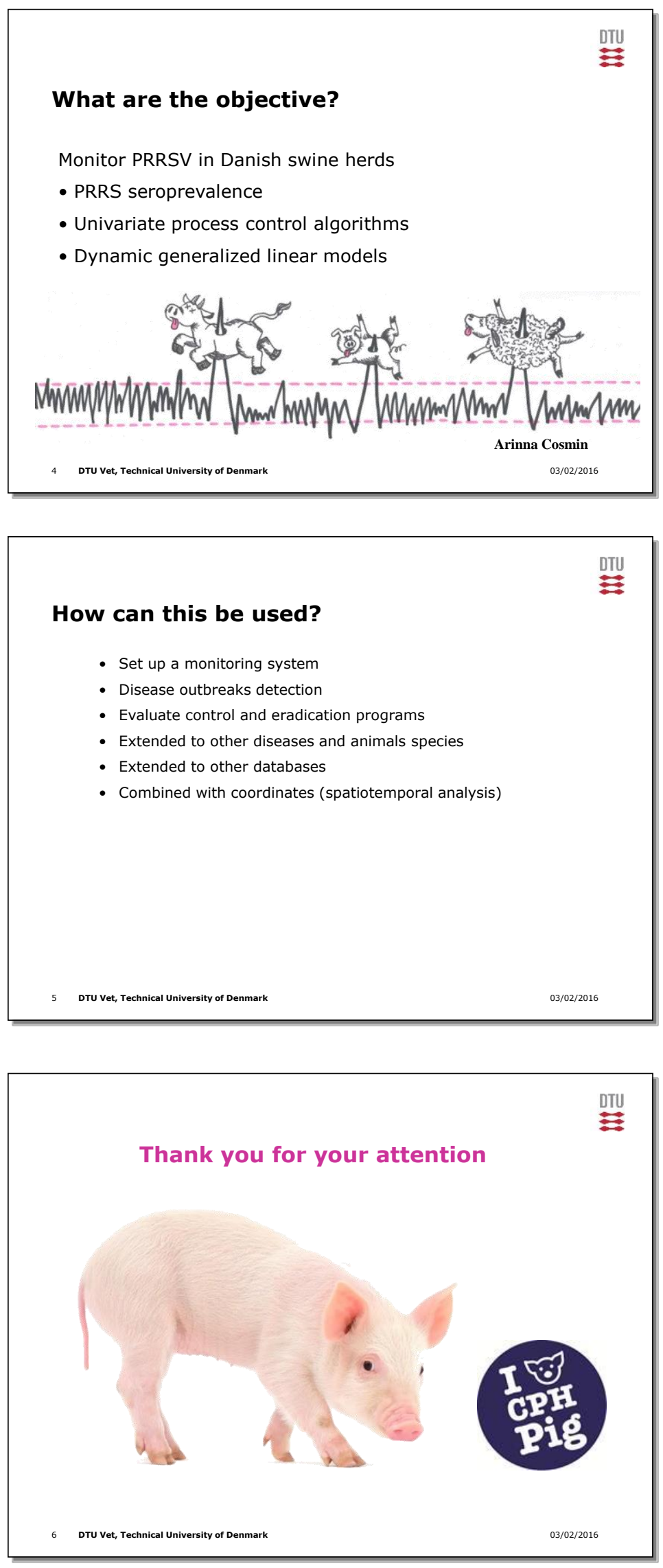
Impact of feeding regime on growth in prepubertal gilts By Sophie Van Vliet, PhD student, Aarhus University 


\section{IMPACT OF FEEDING REGIMEON GROWTH IN PREPUBERTAL GILTS}

Sophie van Vliet' ${ }^{1}$ Thomas S. Bruun², Janni Hales Pedersen ${ }^{3}$, Christian Fink Hansen ${ }^{3}$, Peter K. Theil

${ }^{1}$ Aarhus University

${ }^{2}$ SEGESPig Research Centre

${ }^{3}$ University of Copenhagen

Sophie.vanvliet@au.dk

$A \cup$ AAPUS

\section{BACKGROUND}

Currently most gilts are not fed according to their requirements

\section{Overall aim:}

Reduce feed consumption in gilts/ sows without negatively affecting production and

longevity, by increasing body fat retention and reducing body protein retention in growing

gilts prior to mating

Objectives:

Manipulate growth and body composition in gilts

(Long term consequences of altered body composition - colostrum and milk yield)

$\mathrm{A} U$ 能US

\section{EXPERIMENT}

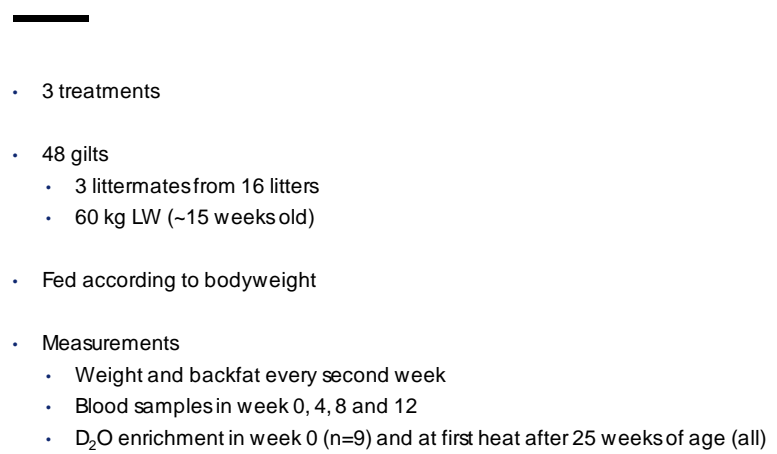

$A \cup$ AAFUS 


\section{TREATMENTS}

LPAD-low protein ad libitum (4.1/3.3 g SID Lys/ FU diet for pregnant sows) High fat deposition -intermediate protein deposition

- MPRE-moderate protein restricted (5.0/4.1 g SID Lys/ FU)

- Low fat deposition-low protein deposition

HPAD - high protein ad libitum (6.6/5.0 g SID Lys/ FU diet for slaughter pigs) - Intermediate fat deposition -high protein deposition

\section{A U AARUS}

\section{FEFD INTAKE}

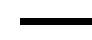

Treatment ${ }^{* * *} ;$ Week $^{* * *} ; \mathrm{TxW}^{* * *}$

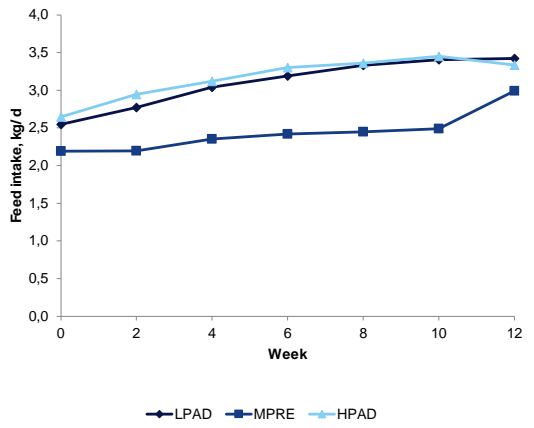

$A \cup$ AARHS

\section{THREE UTTERMATES}

\section{Week 12}
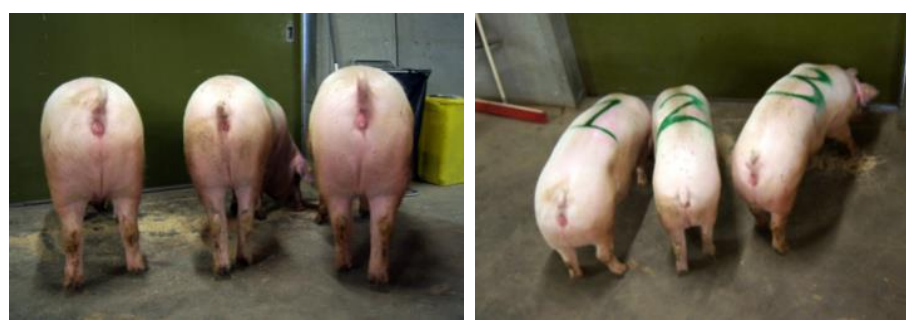

$A \cup$ AANUUS 

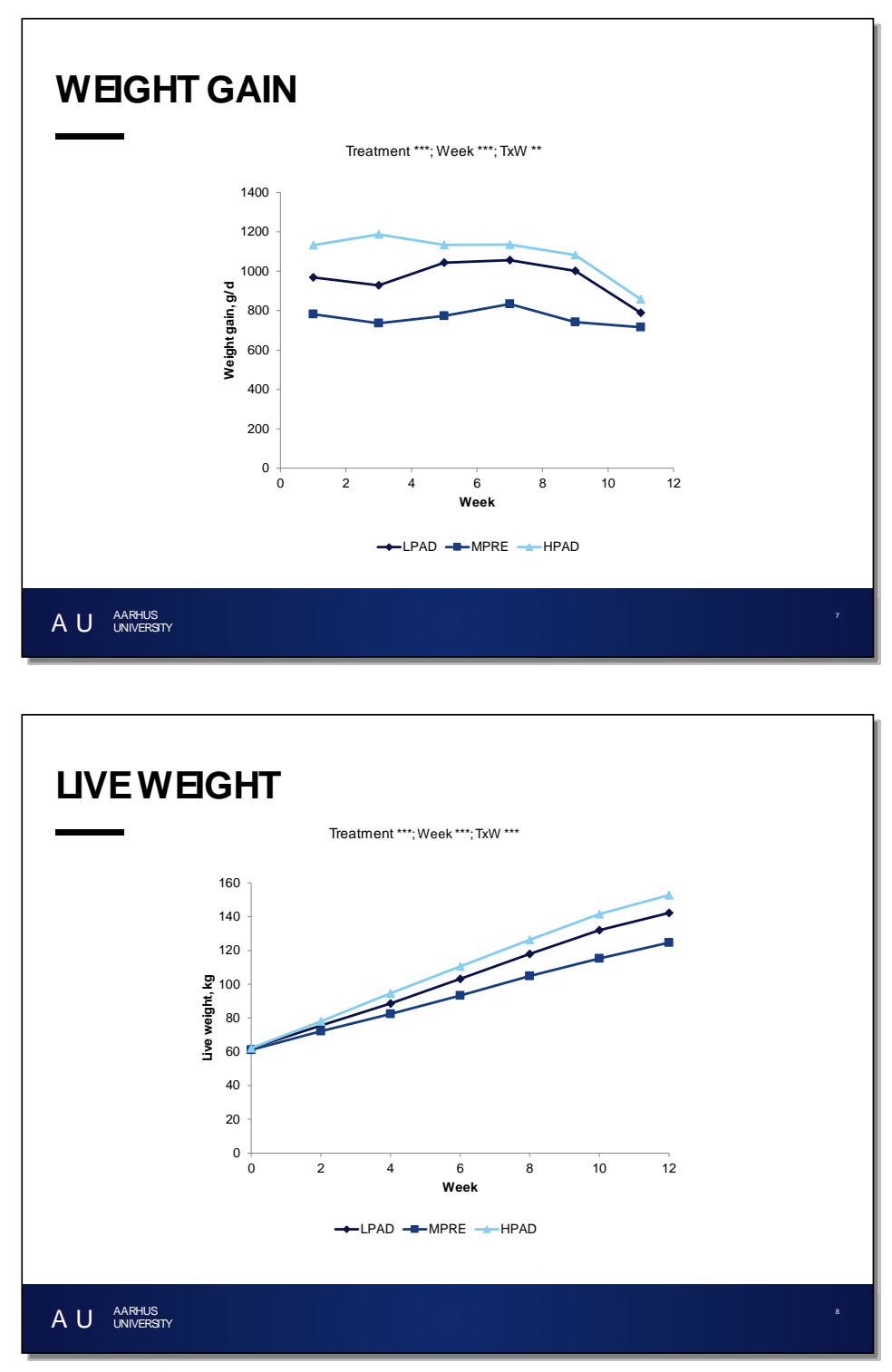

\section{BACKFAT}

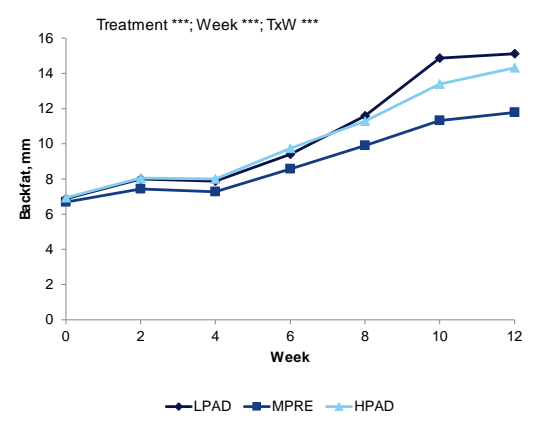

A U ANAUUS 


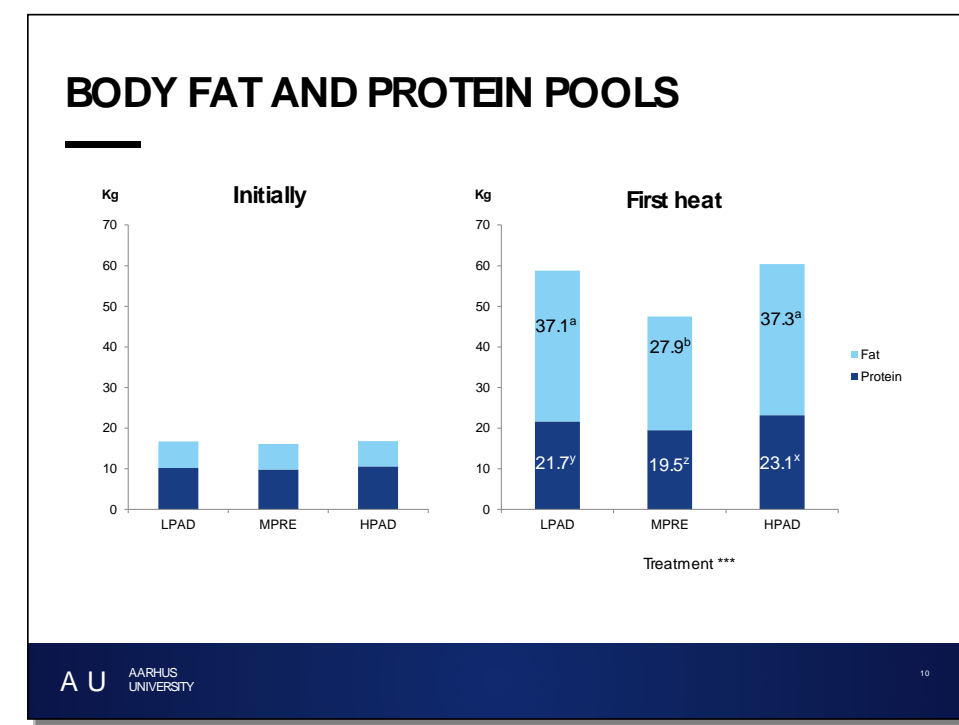

\section{PLASMA METABOUTES}

\begin{tabular}{lcccc}
\hline & \multicolumn{3}{c}{ Treatment } & \\
\cline { 2 - 4 } & LPAD & MPRE & HPAD & $P$-value \\
\hline Glucose, mM & 5.57 & 5.46 & 5.57 & 0.30 \\
Lactate, $\mathrm{mM}$ & $3.01^{\mathrm{a}}$ & $3.02^{\mathrm{a}}$ & $2.34^{\mathrm{b}}$ & 0.03 \\
Urea, $\mathrm{mM}$ & $3.91^{\mathrm{a}}$ & $3.40^{\mathrm{b}}$ & $3.50^{\mathrm{b}}$ & $<.001$ \\
NEFA, $\mu \mathrm{M}$ & $27.7^{\mathrm{b}}$ & $28.0^{\mathrm{b}}$ & $34.1^{\mathrm{a}}$ & 0.004 \\
Triglycerides, mM & $0.31^{\mathrm{b}}$ & $0.33^{\mathrm{b}}$ & $0.37^{\mathrm{a}}$ & $<.001$ \\
Insulin, pM & $26.0^{\mathrm{a}}$ & $17.8^{\mathrm{b}}$ & $31.2^{\mathrm{a}}$ & $<.001$ \\
IGF-1, ng/mL & $147^{\mathrm{b}}$ & $144^{\mathrm{b}}$ & $168^{\mathrm{a}}$ & 0.002 \\
\hline
\end{tabular}

$\mathrm{A} \cup$ AARHS

\section{CONCLUSION}

\section{-}

Body fat and protein retention can be altered by feeding regime

LPAD-high fat retention and intermediate protein retention

- MPRE-low fat and protein retention

- HPAD-high protein retention and intermediate fat retention

Follow up study -> the effects of altered body composition on colostrum and milk yield

$A \cup$ AARAUS 
THANK YOU FOR YOUR ATTIENTION

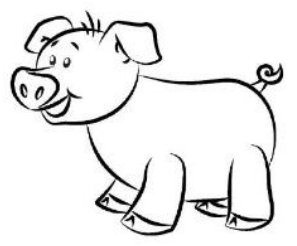

$A \cup$ AAAUS 
Increasing the dietary level of protein for lactating sows affects litter gain and sow weight loss

By Thomas Sønderby Bruun, Senior Specialist, SEGES Pig Research Centre 


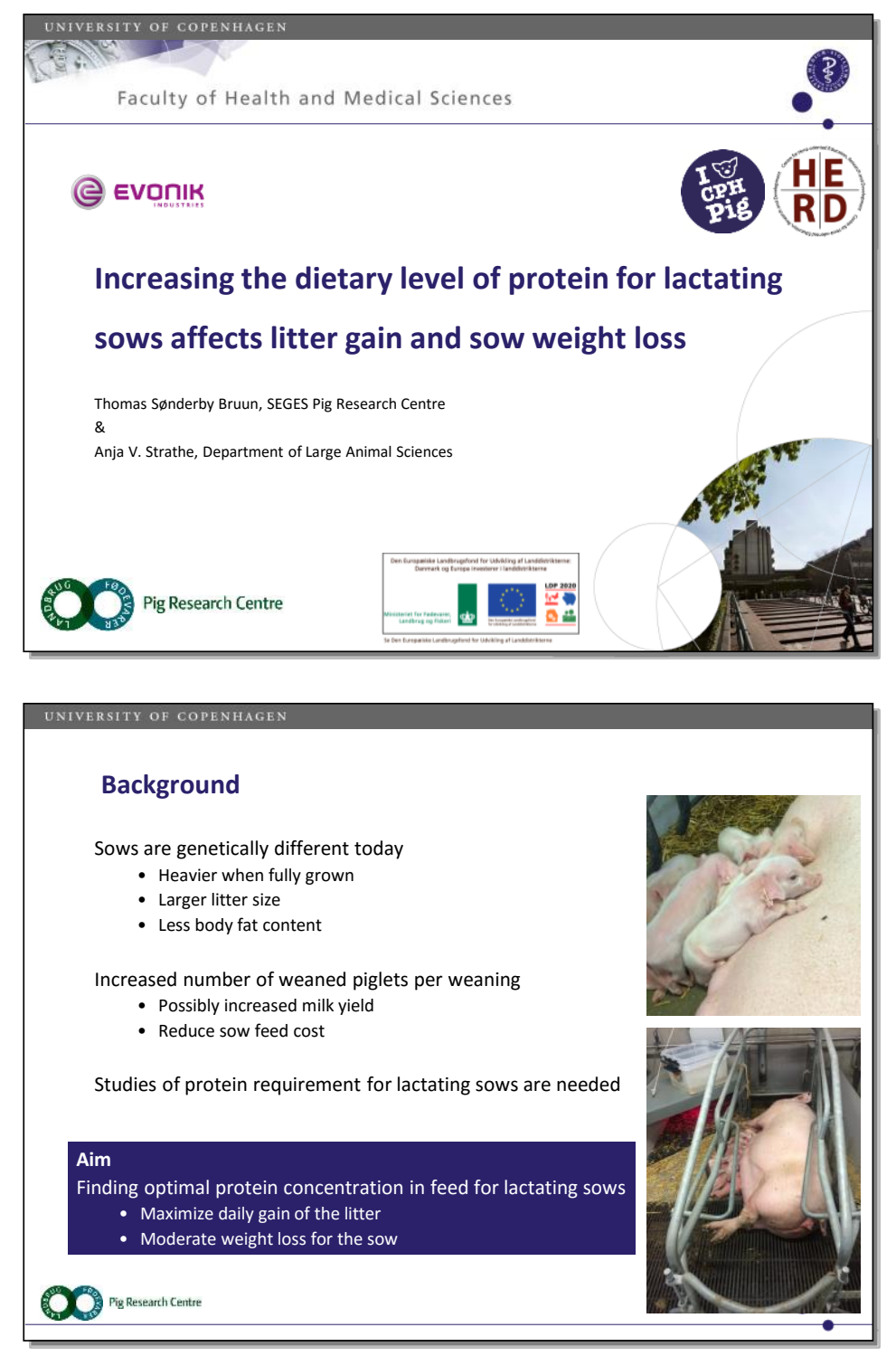

\begin{tabular}{|c|c|c|c|c|c|c|}
\hline \multicolumn{7}{|c|}{ Materials and methods - Feed composition } \\
\hline Treatment & 1 & 2 & 3 & 4 & 5 & 6 \\
\hline $\begin{array}{l}\text { Energy } \\
\text { FUsow per kg }\end{array}$ & $\begin{array}{l}1.06 \\
1.06\end{array}$ & $\begin{array}{l}1.06 \\
1.06\end{array}$ & $\begin{array}{l}1.06 \\
1.06\end{array}$ & $\begin{array}{l}1.06 \\
1.06\end{array}$ & $\begin{array}{l}1.06 \\
1.06\end{array}$ & $\begin{array}{l}1.06 \\
1.06\end{array}$ \\
\hline $\begin{array}{l}\text { SID lysine } \\
\text { g per FUsow }\end{array}$ & $\begin{array}{l}5.5 \\
5.6\end{array}$ & $\begin{array}{l}6.1 \\
6.2\end{array}$ & $\begin{array}{l}6.6 \\
6.7\end{array}$ & $\begin{array}{l}7.1 \\
7.1\end{array}$ & $\begin{array}{l}7.8 \\
7.8\end{array}$ & $\begin{array}{l}8.5 \\
8.5\end{array}$ \\
\hline $\begin{array}{l}\text { SID crude protein } \\
\mathrm{g} \text { per FUsow }\end{array}$ & $\begin{array}{c}92 \\
99 \hat{\iota}\end{array}$ & $\begin{array}{c}101 \\
108 \hat{}\end{array}$ & $\begin{array}{c}108 \\
115 \hat{\imath}\end{array}$ & $\begin{array}{c}116 \\
122 \Uparrow\end{array}$ & $\begin{array}{c}126 \\
133 \Uparrow\end{array}$ & $\begin{array}{c}136 \\
143 \hat{\imath}\end{array}$ \\
\hline \multicolumn{7}{|c|}{$\begin{array}{l}\text { Black = planned } \\
\text { Pink = realized }\end{array}$} \\
\hline Pgg Research Centre & & & & & & \\
\hline
\end{tabular}



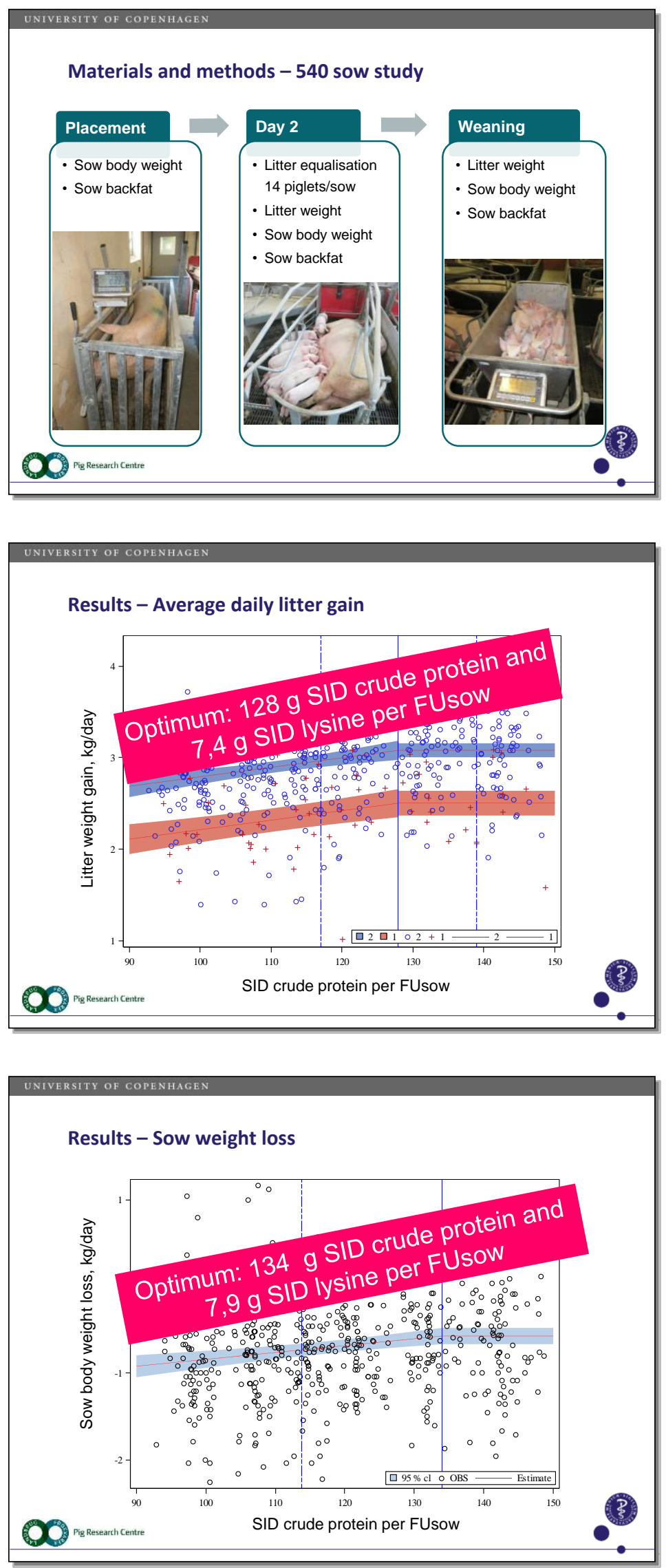

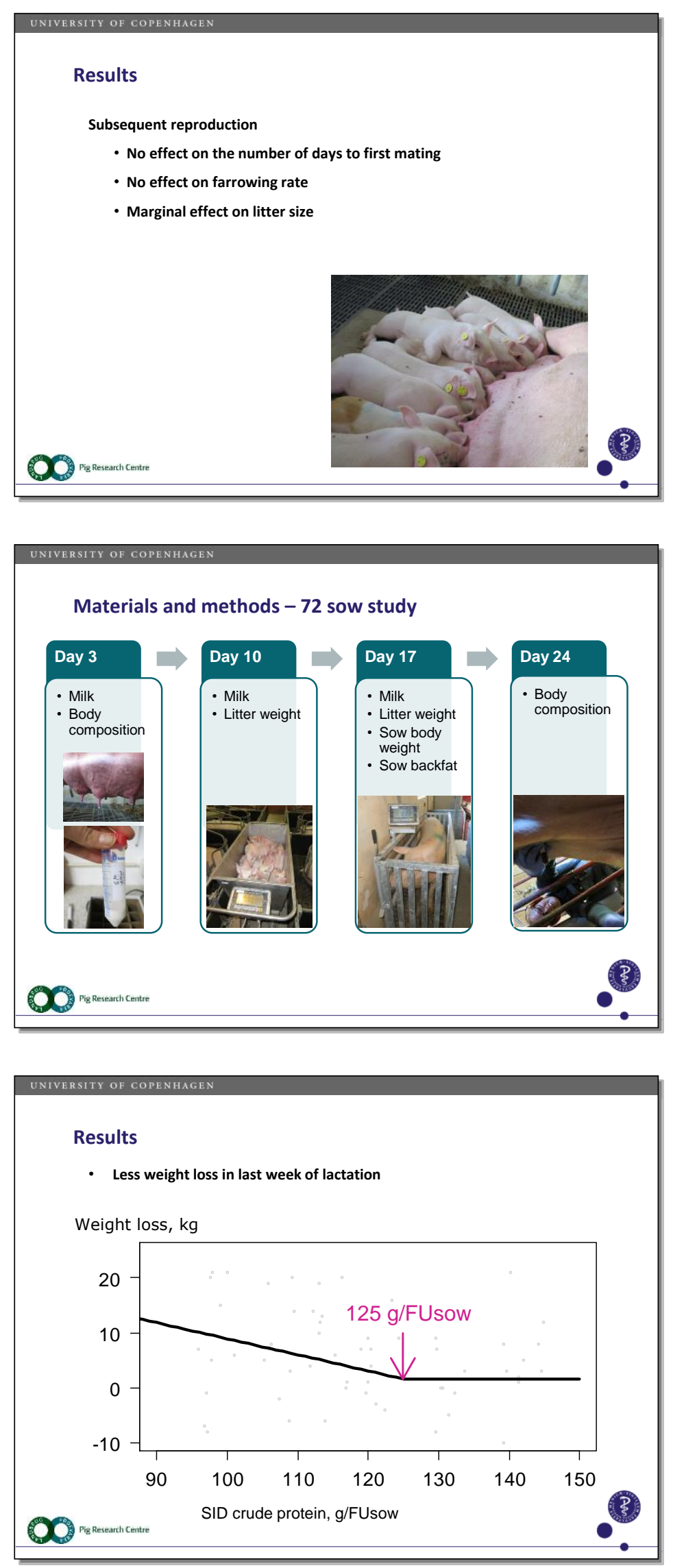

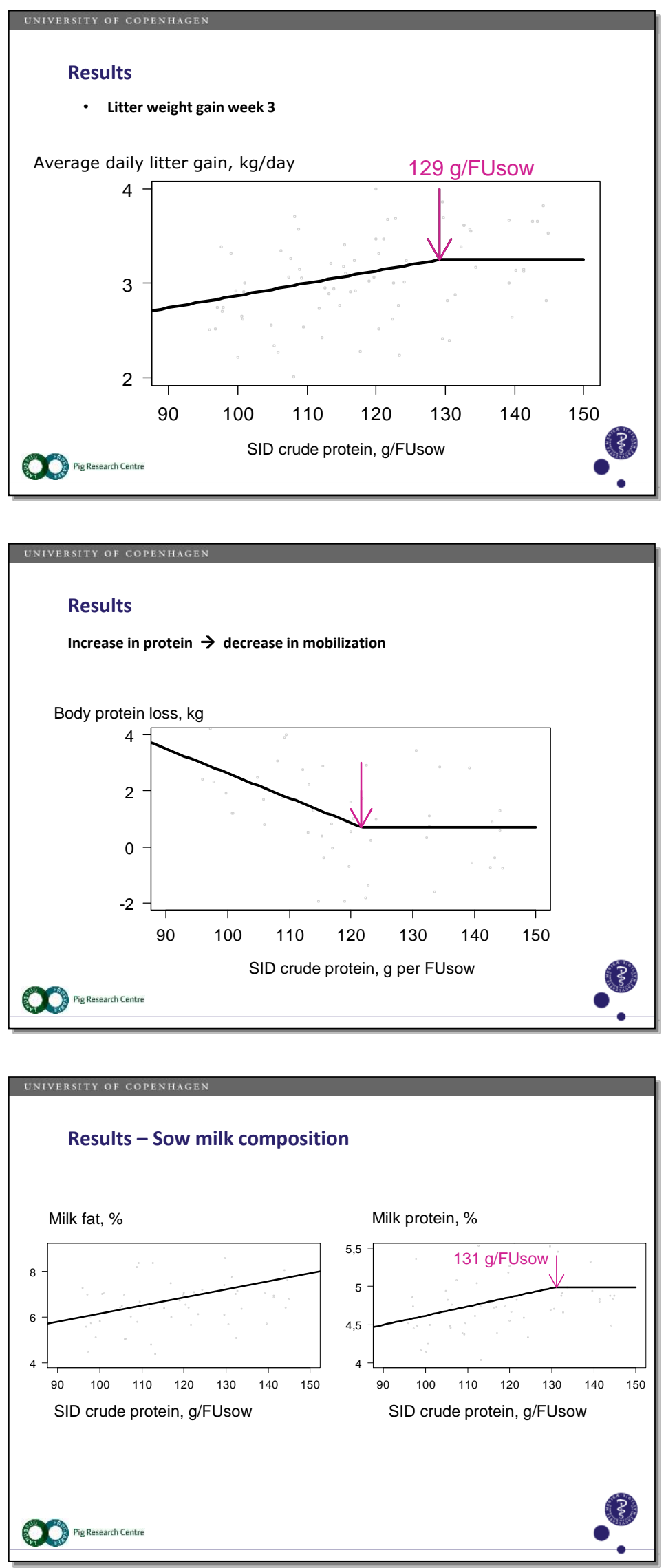


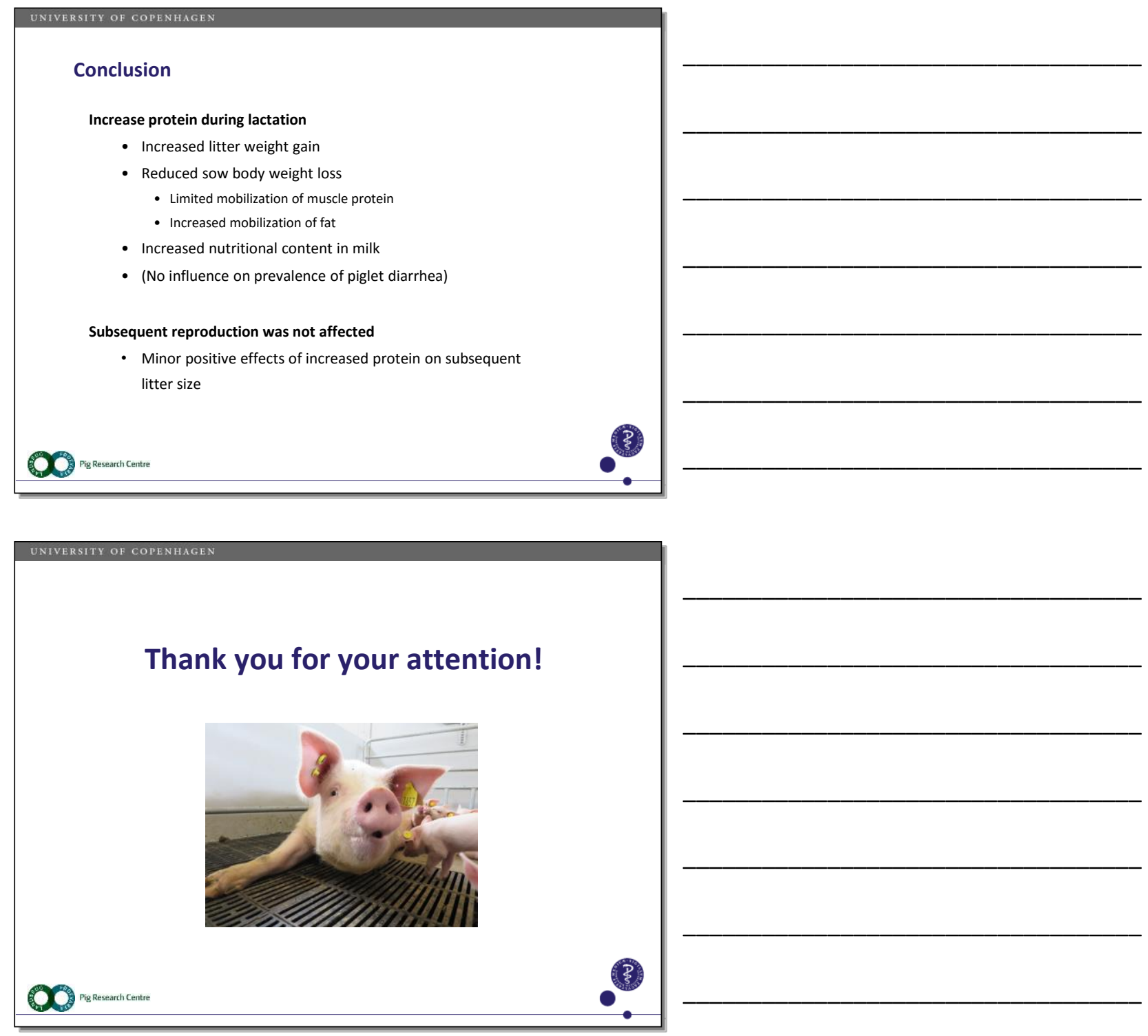


Gastric emptying rate and blood values in newborn intra-uterine growth restricted piglets

By Charlotte Amdi Williams, Post doc., Department of Large Animal Sciences, University of Copenhagen 

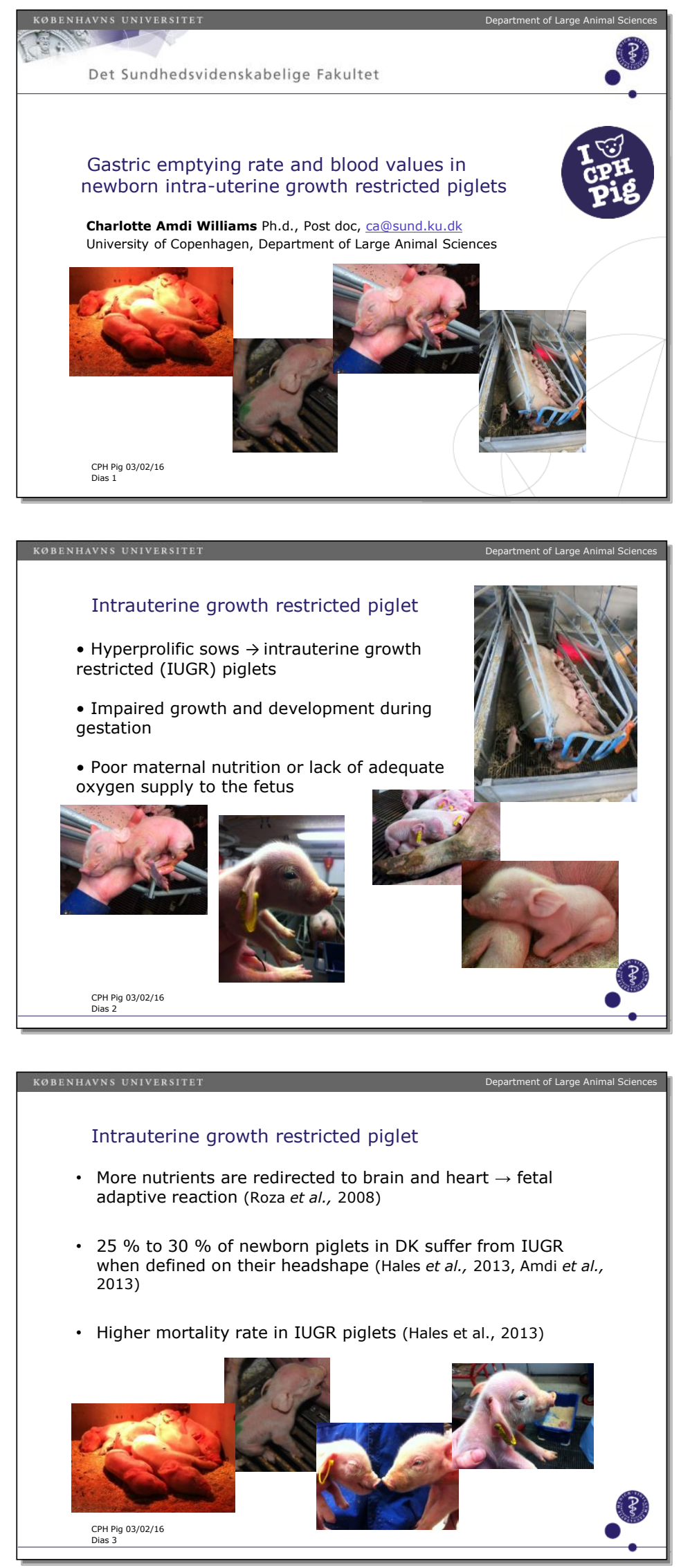

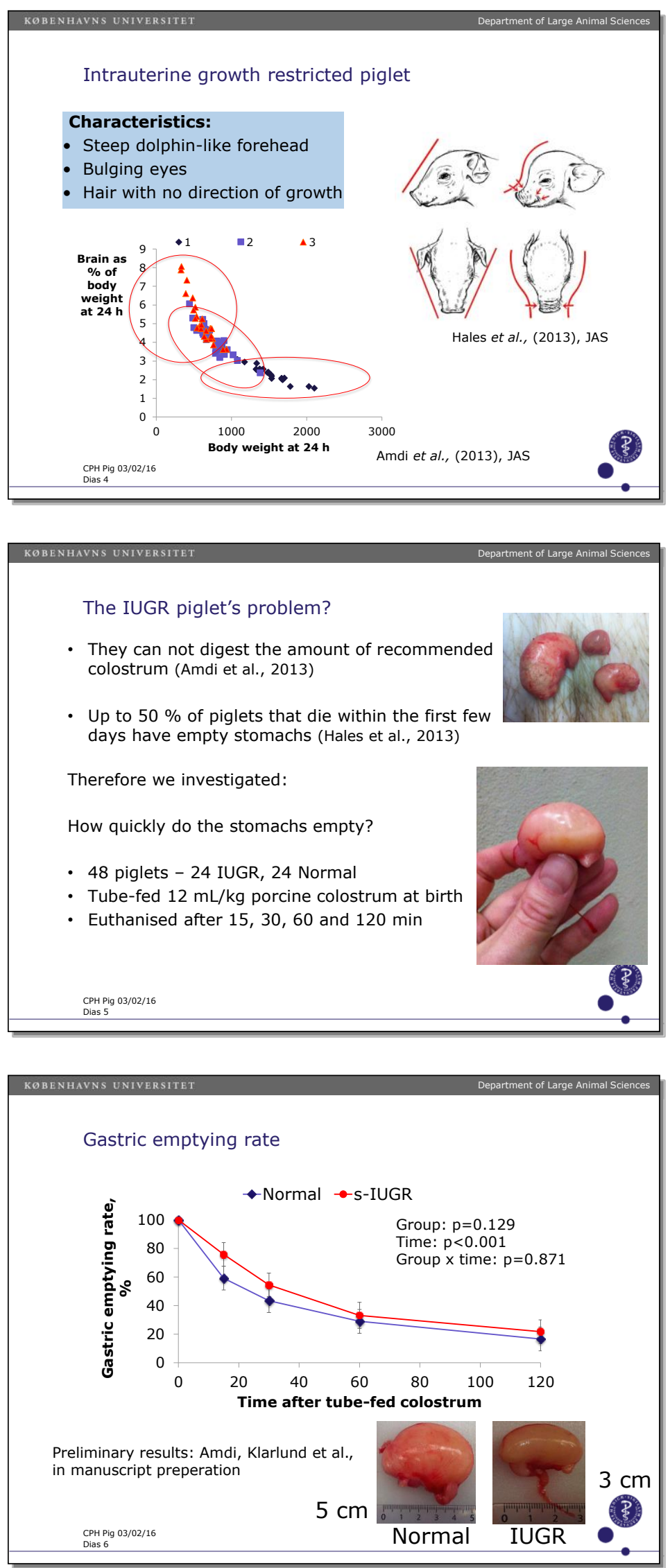

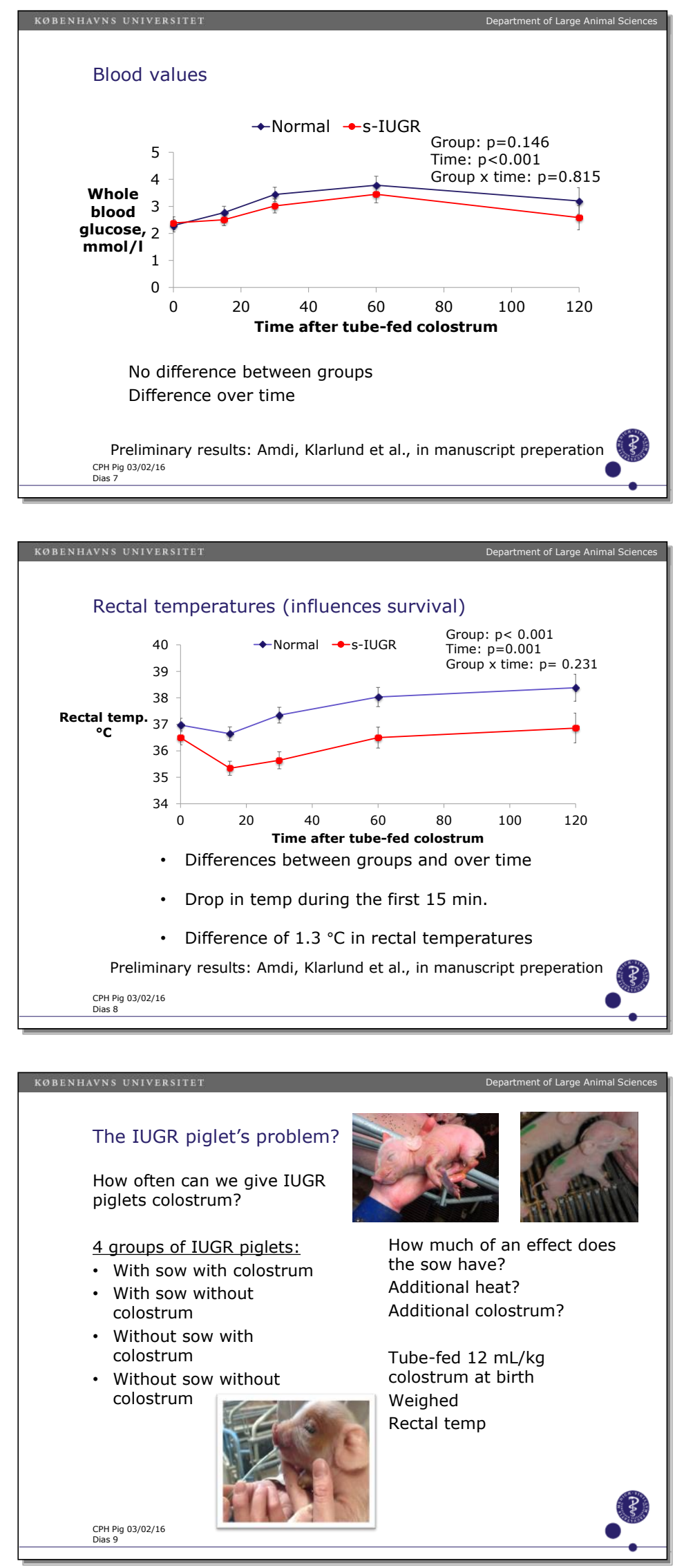

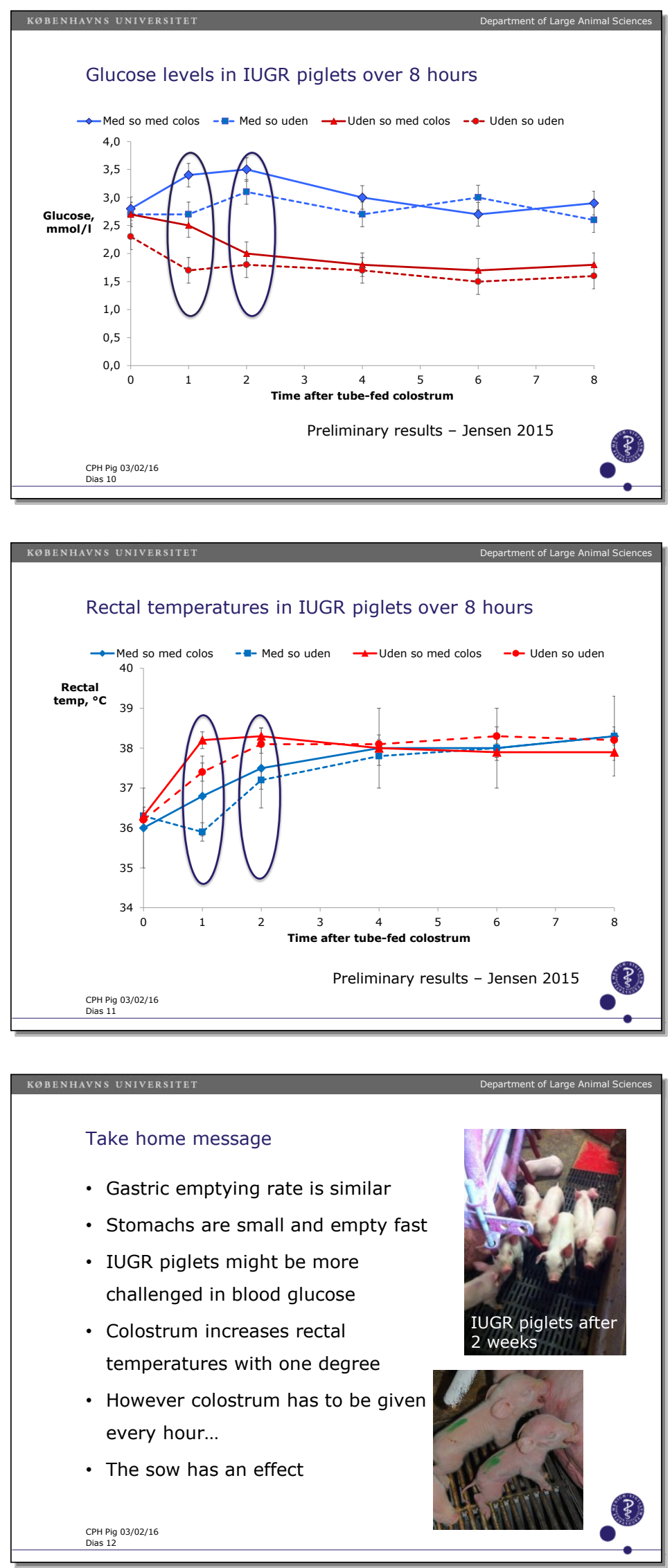


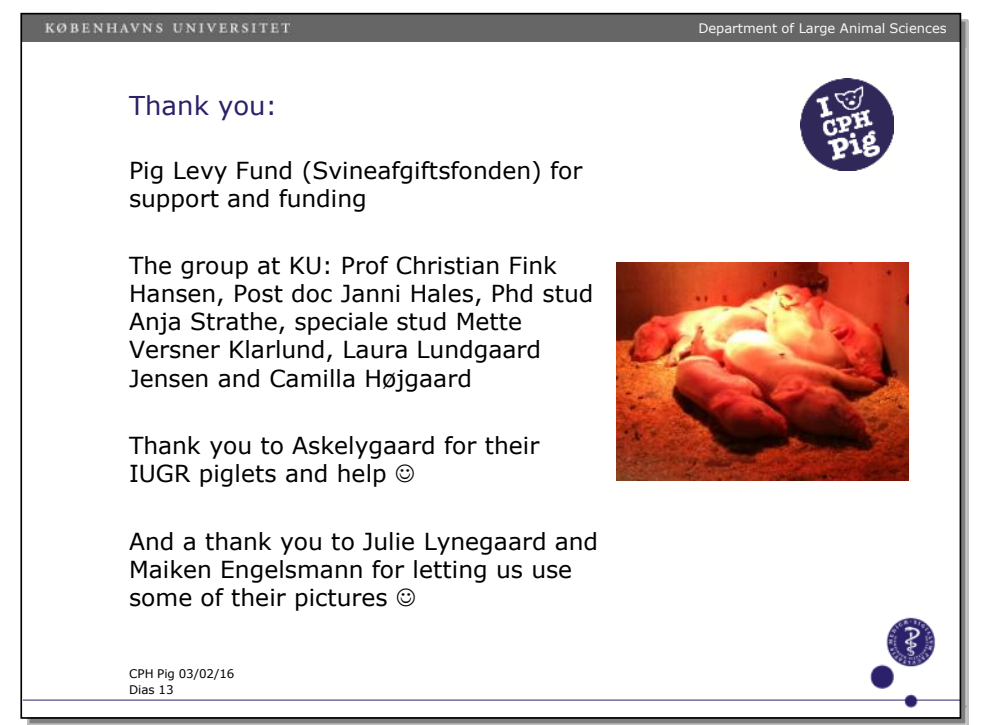


Session 3: Welfare 
The use of virtual herds in veterinary and agricultural education By Karl Johan Møller Klit, PhD student, Department of Large Animal Sciences, University of Copenhagen 


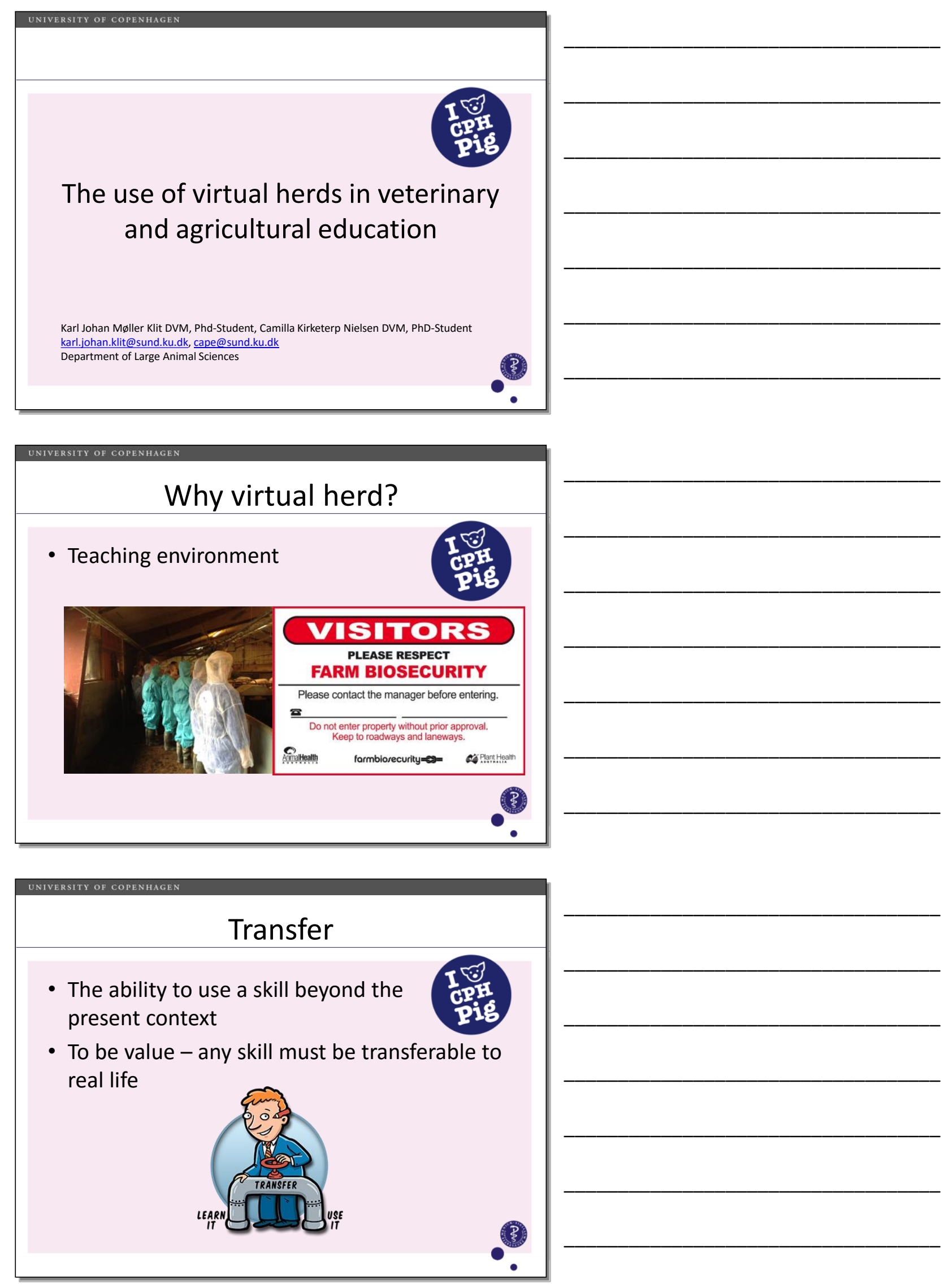



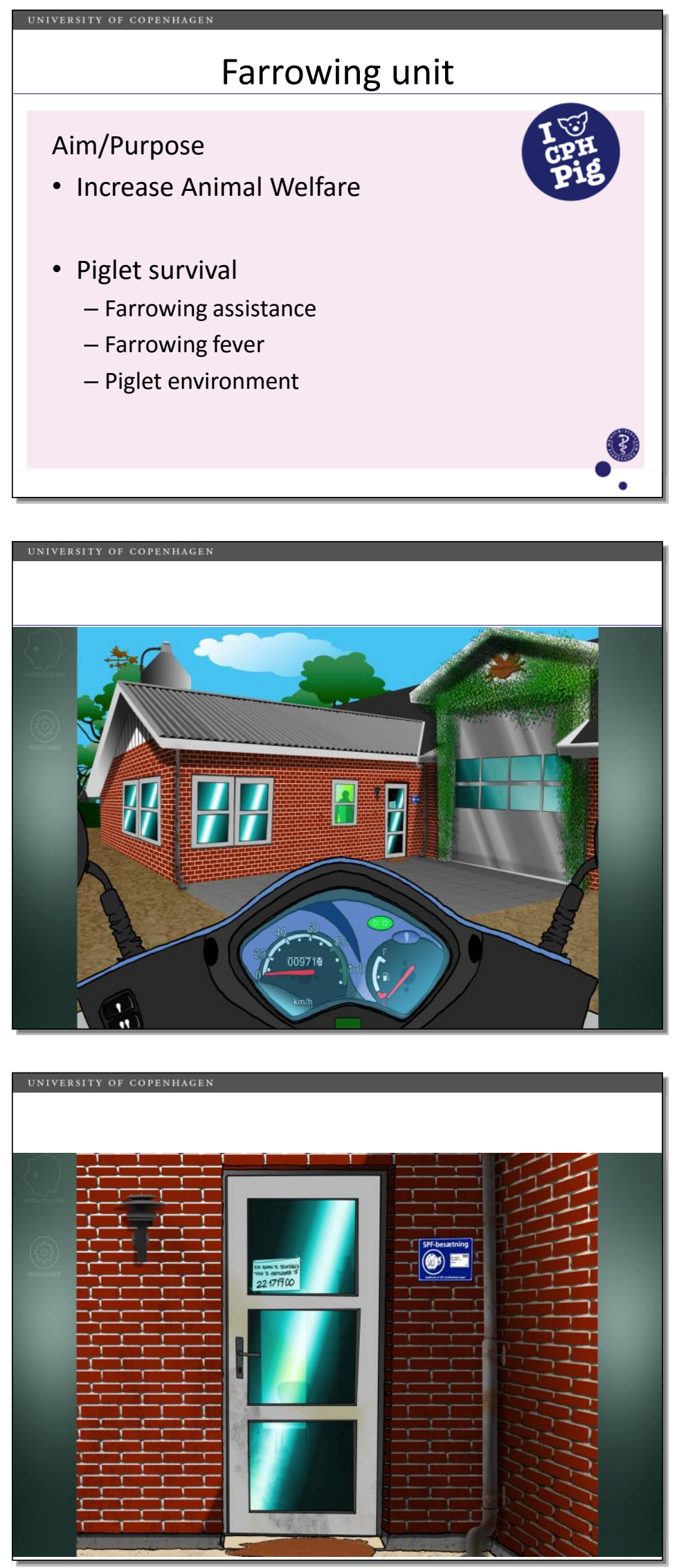

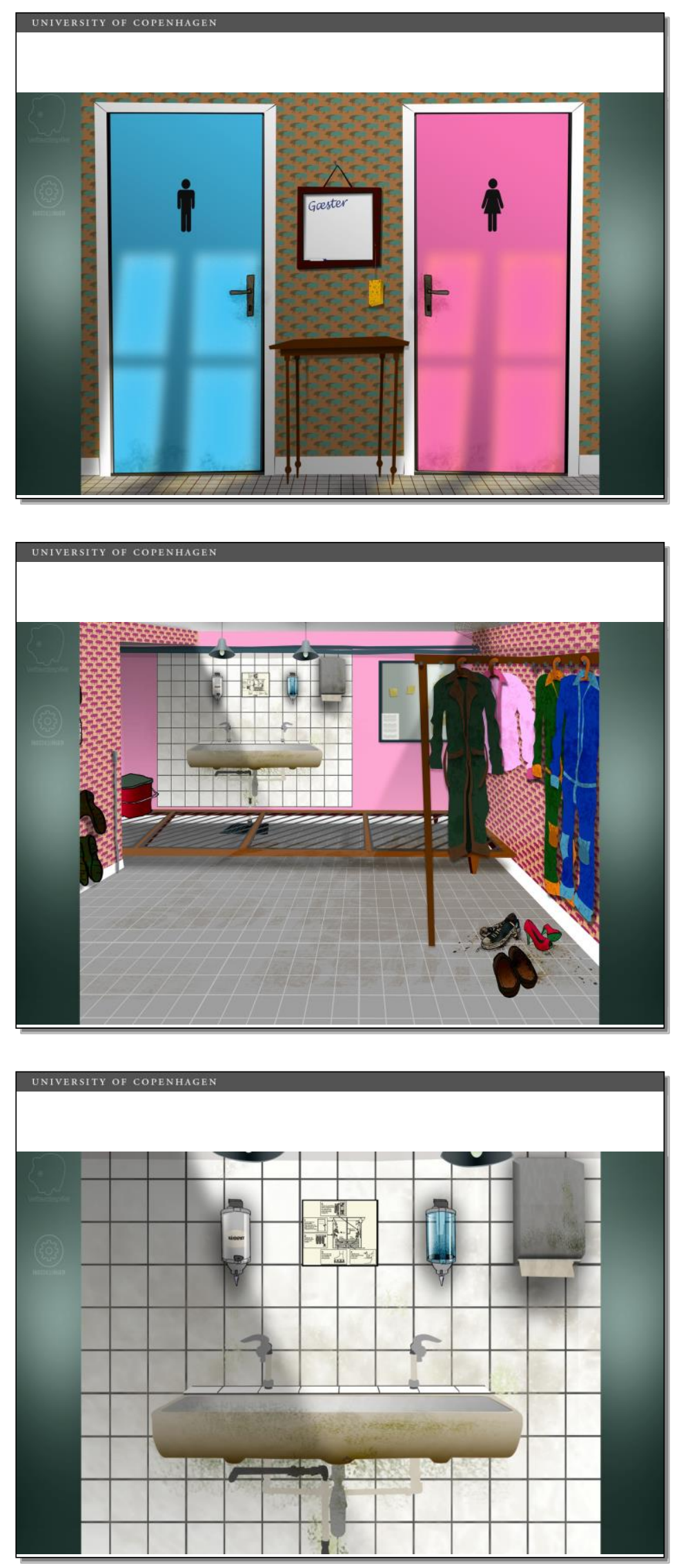

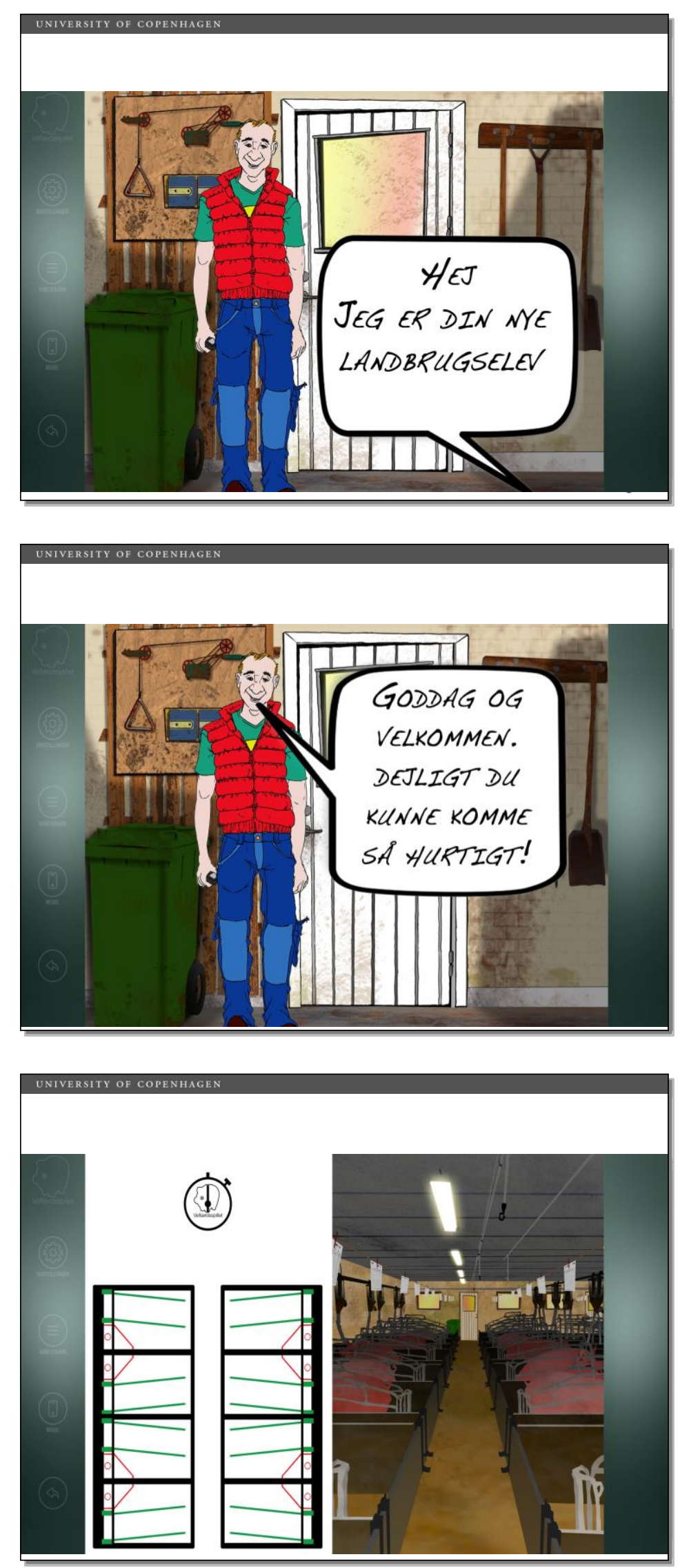

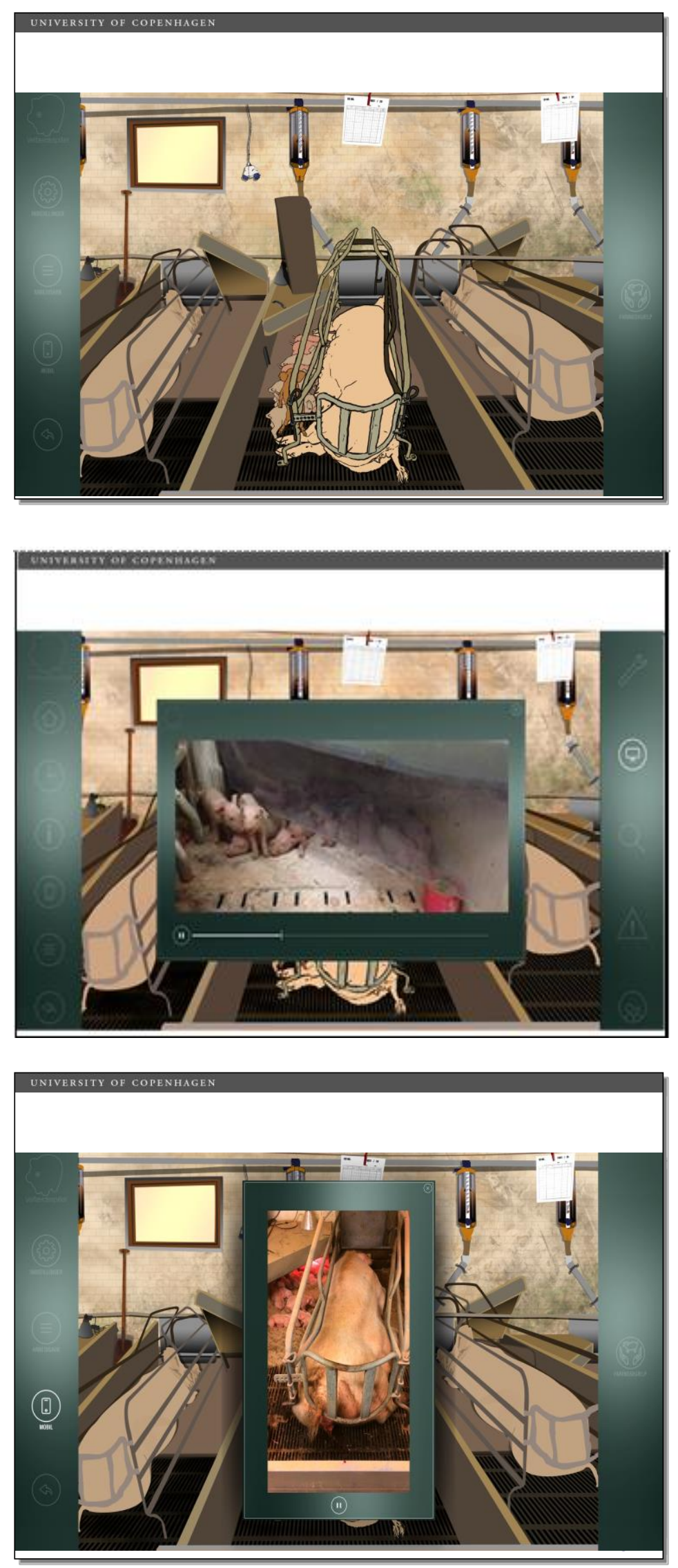


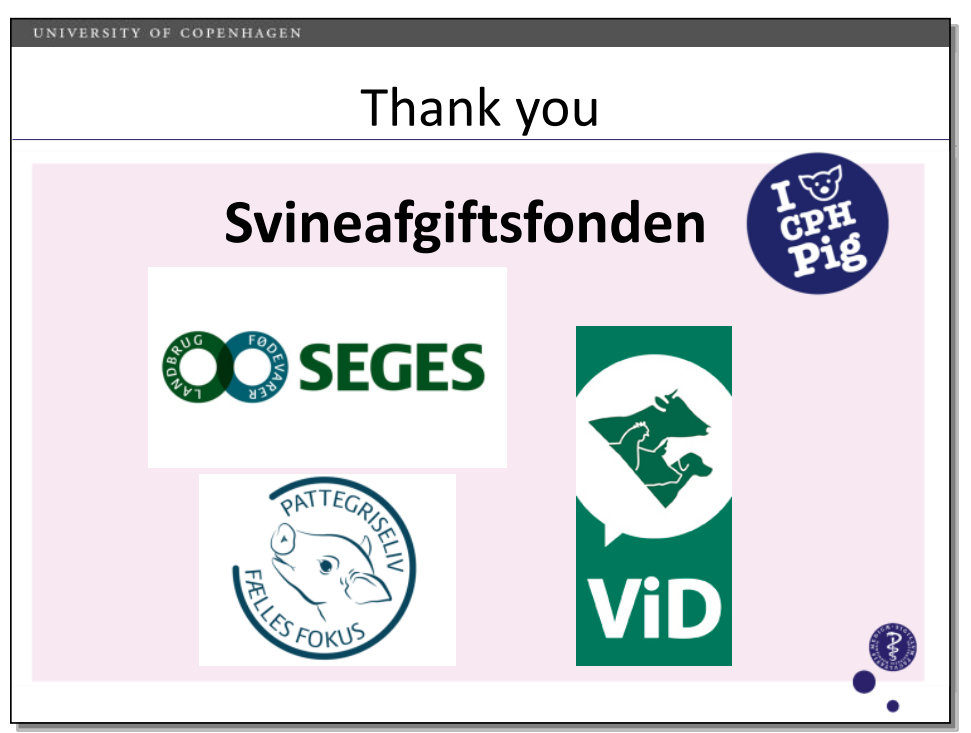


Assessing farms with the Danish animal welfare index By Marlene Kirchner, Assistant professor, Department of Large Animal Sciences, University of Copenhagen 

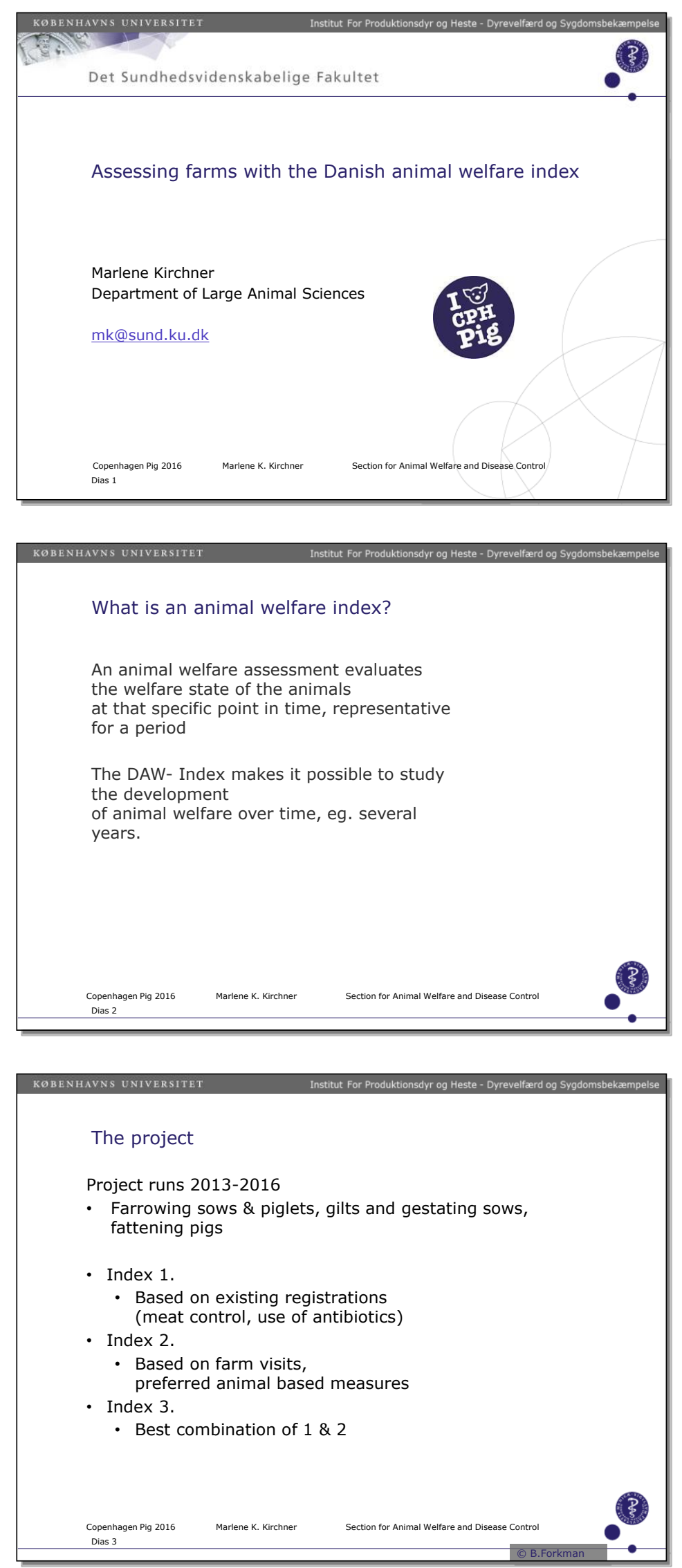

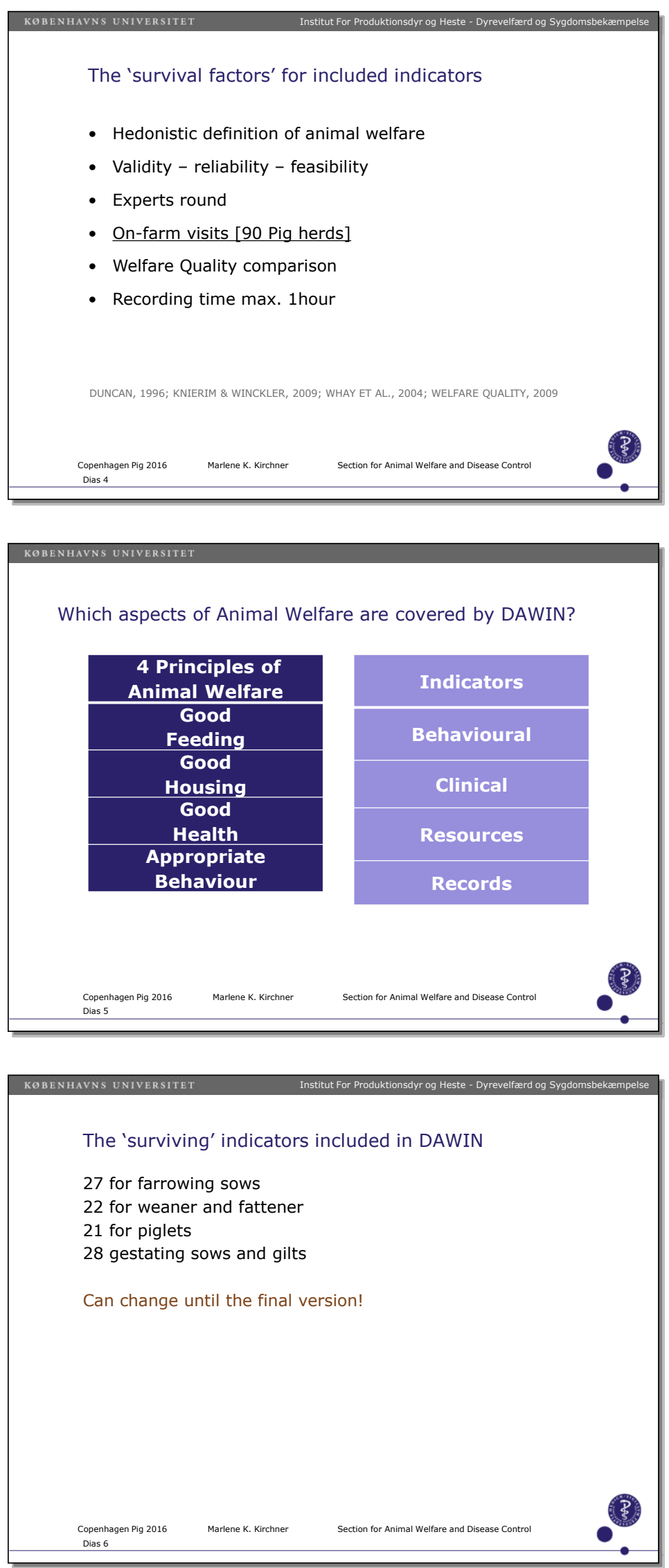


\begin{tabular}{|c|c|c|}
\hline \multicolumn{3}{|c|}{ Farrowing sows - part 1} \\
\hline Principles (WQ) & Indicators & Type \\
\hline \multirow[t]{4}{*}{ Good Feeding } & Body condition score $(0 / 1)$ & Animal-based \\
\hline & Roughage (No/Access to roughage) & Resource-based \\
\hline & Feeding system (Non/competitive) & Resource-based \\
\hline & Water supply (clean/sufficient) & Resource-based \\
\hline \multirow[t]{9}{*}{ Good Housing } & Farrowing system & Resource-based \\
\hline & Farrowing rails & Resource-based \\
\hline & Space in farrowing system & Resource-based \\
\hline & Resting area & Resource-based \\
\hline & Ammonia & Resource-based \\
\hline & Manure on the body & Animal-based \\
\hline & Bursitis & Animal-based \\
\hline & Panting & Animal-based \\
\hline & Nursing sows & Animal-based \\
\hline $\begin{array}{l}\text { Copenhagen Pig } 2016 \\
\text { Dias } 7\end{array}$ & Section for Animal ws & \\
\hline
\end{tabular}

\begin{tabular}{|c|c|c|}
\hline \multicolumn{3}{|c|}{ Farrowing sows - part 2} \\
\hline Principles (WQ) & Indicators & Type \\
\hline \multirow[t]{11}{*}{ Good health } & Hampered respiration & Animal-based \\
\hline & Shoulder wounds & Animal-based \\
\hline & Integument alterations & Animal-based \\
\hline & Vulva lesions & Animal-based \\
\hline & Prolapse & Animal-based \\
\hline & Hernia & Animal-based \\
\hline & Nose ring & Animal-based \\
\hline & Overgrown claws & Animal-based \\
\hline & Proper euthanasia & Resource-based \\
\hline & Hospital pens & Resource-based \\
\hline & Mortality & Resource-based \\
\hline \multirow{3}{*}{$\begin{array}{l}\text { Appropriate } \\
\text { Behaviour }\end{array}$} & Stereotypies & Animal-based \\
\hline & Rooting material & Resource-based \\
\hline & Possibility to perform nest building behaviour & Resource-based \\
\hline
\end{tabular}

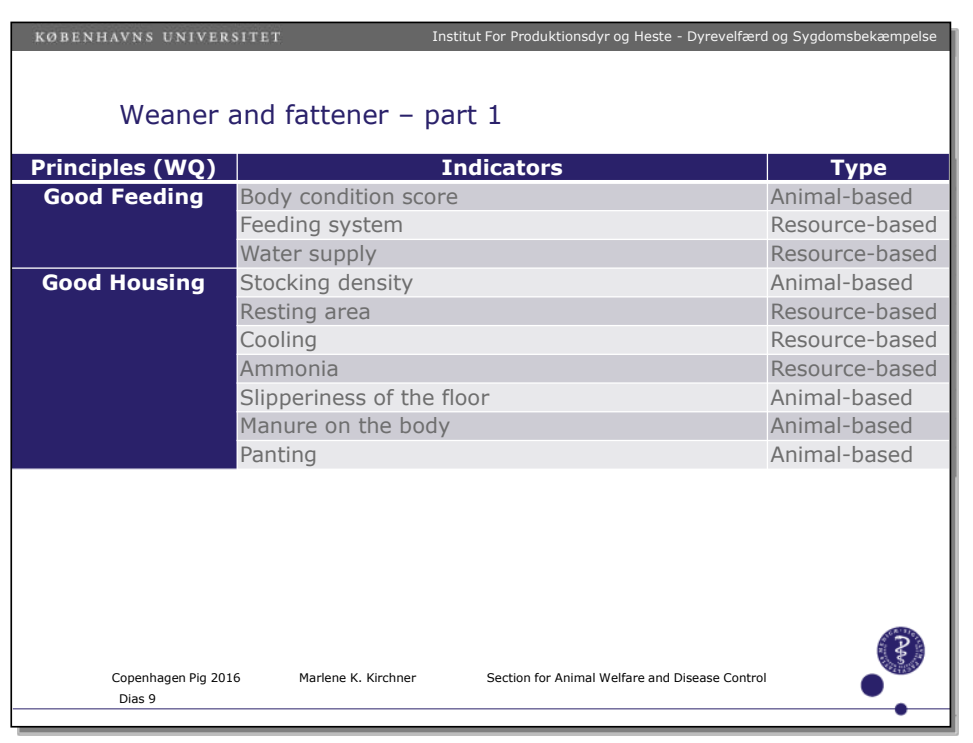



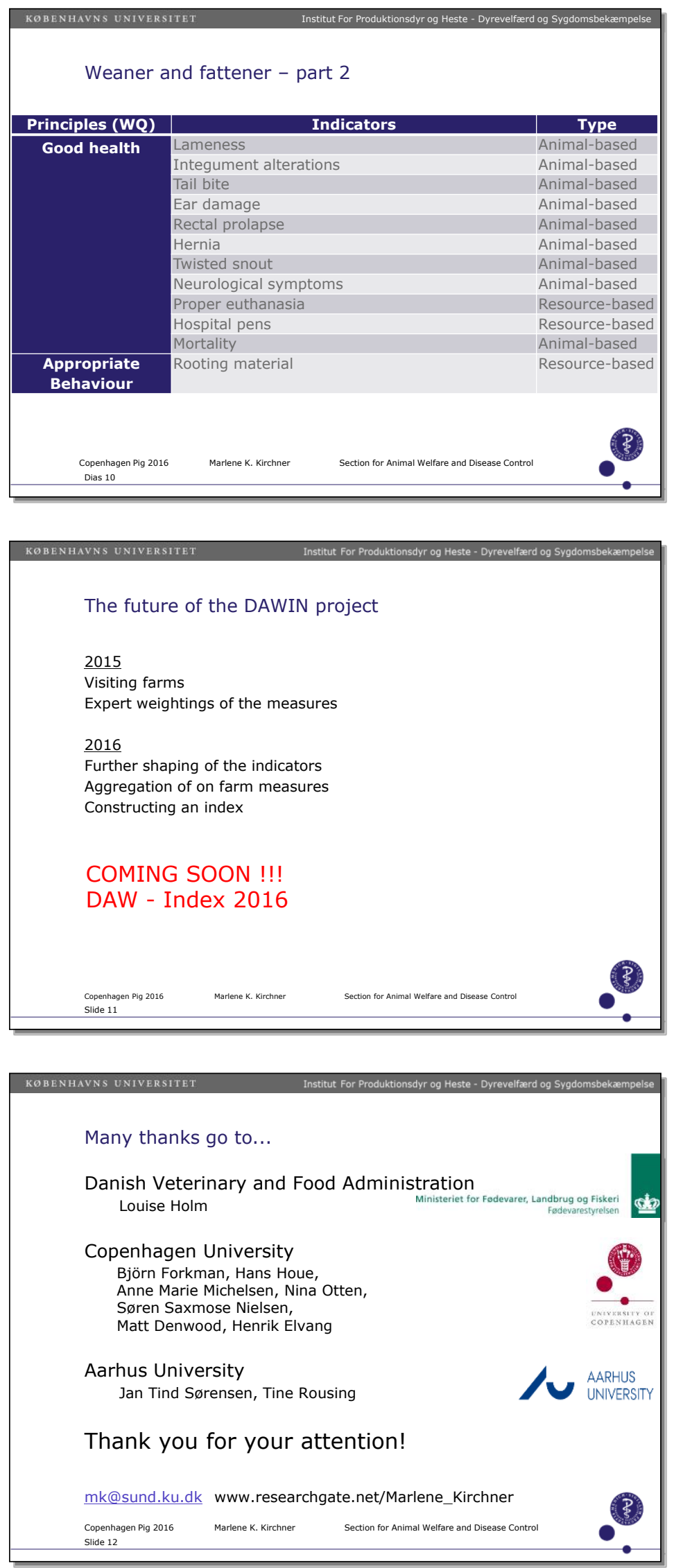
Tail biting: prevalence among docked and undocked pigs from weaning to slaughter

By Helle Pelant Lahrmann, Industrial PhD student, Department of Large Animal Sciences, University of Copenhagen \& SEGES Pig Research Centre 


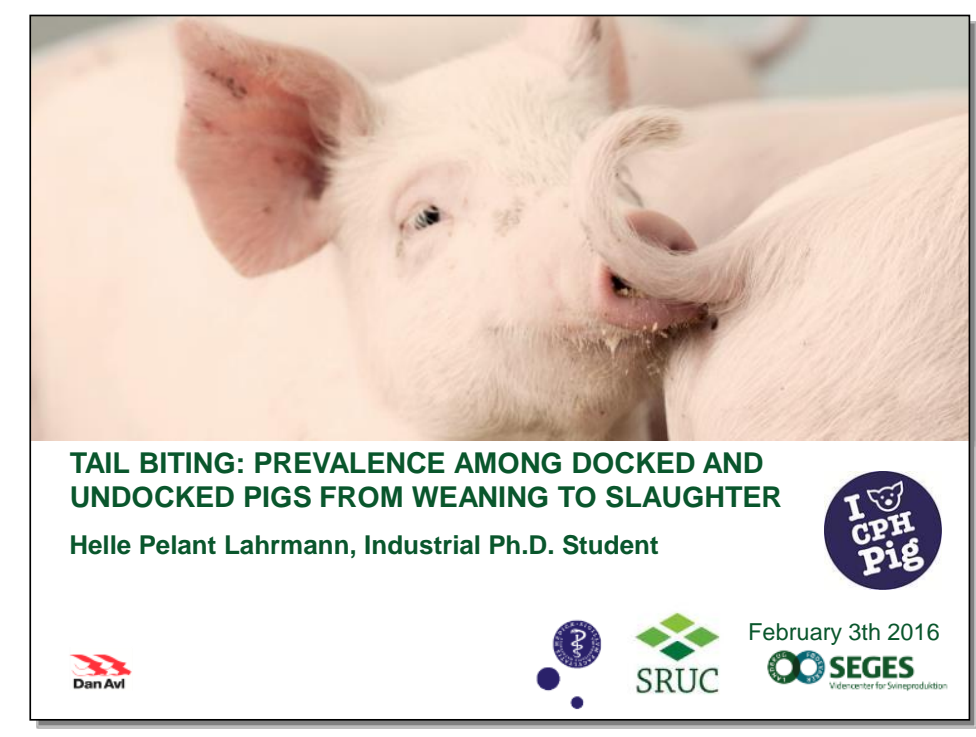

\section{INTRODUCTION}

- EU directive bans routine tail docking

- More than $95 \%$ of European pigs are tail docked (EFSA 2007)

- Estimated 3.1\% of Danish pigs tail bitten despite the tail docking procedure (D'Earth et al., 2014)

- The consequences of a cessation of tail docking in conventional Danish piggeries are not known

\section{Study aim}

Determine consequences of tail docking cessation on tail biting in a well-managed Danish conventional herd.

\section{OO SEGES}

\section{DEFINITION TAIL BITING \& TAIL LESION}

- Tail biting is a behaviour - damaging or non-damaging

- Definition damaging tail biting

- Pig's chew on a pen mates tail resulting in a bloody wound on the tail (Munsterhjelm et al. 2013)

- Damaging tail biting

- is painful to the pig

- can develop to such an extent that the pig looses the majority of the tail

- increases the risk of infections

- increases the need for antibiotic treatments

- may cause death or euthanasia (Kritas \& Morrison 2004 \& 2007)

- Tail lesion is a condition

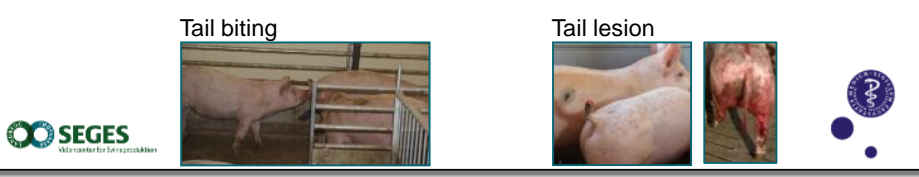




\section{MATERIAL \& METHODS}

- Two groups

- +/- tail docking

- Housing

- Same pen from weaning to slaughter (stable group)

- Docked and undocked pigs in different pens

20-22 pigs per pen, mixed gender

- Daily provision of $\sim 230 \mathrm{~g}$ straw on the floor until $70 \mathrm{~kg}+$ two vertical wooden sticks per pen

If tail biting occurred a Bite Rite was added and the amount of straw was doubled

- Animals

- LYD - pigs, castrated males, individually earmarked

\section{OOSEGES}
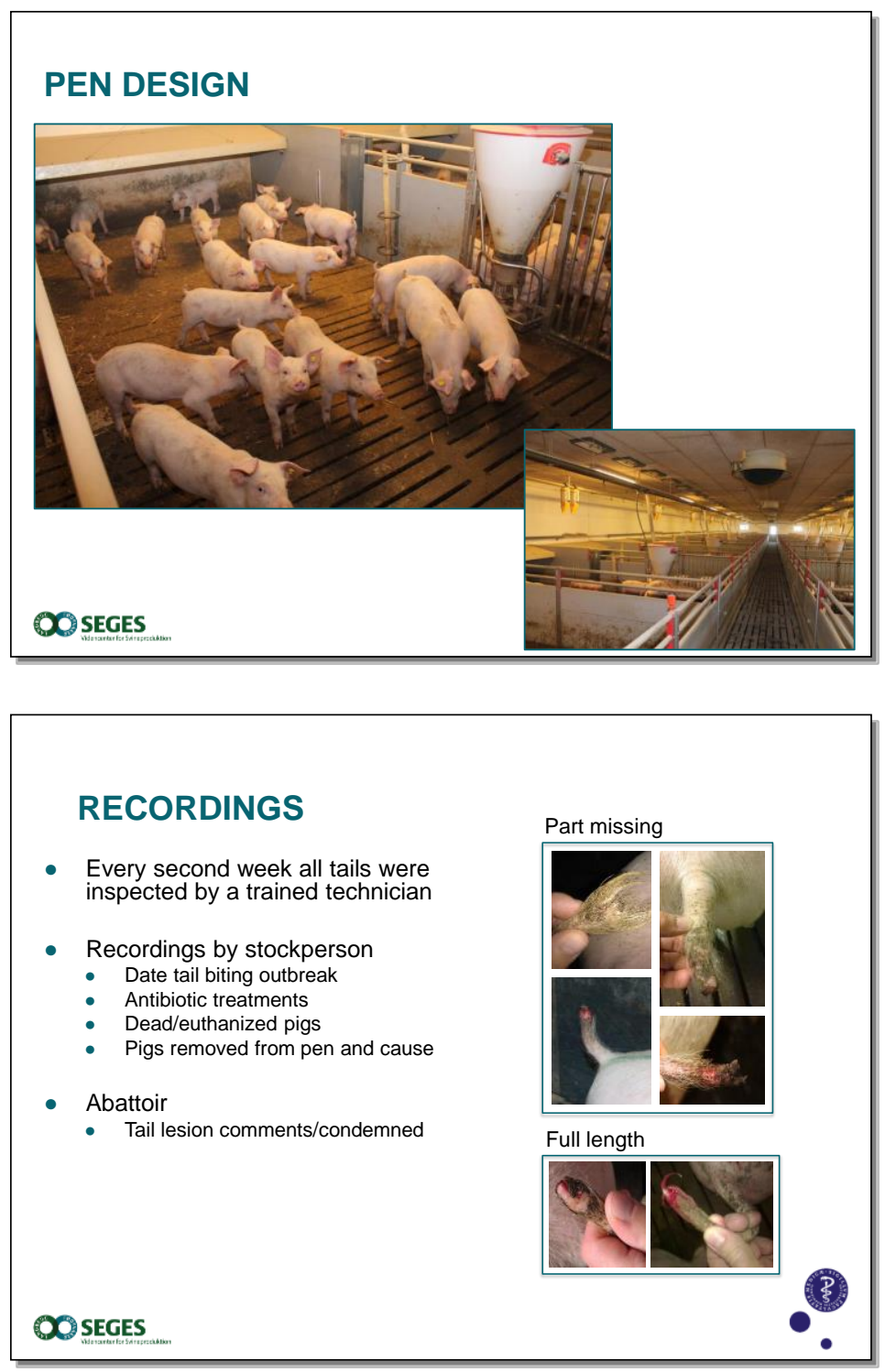


\section{PRELIMINARY RESULTS}

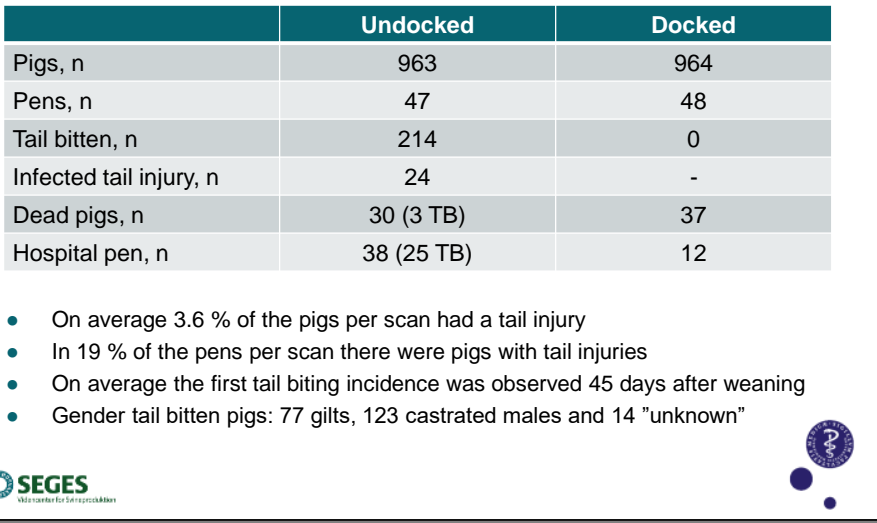

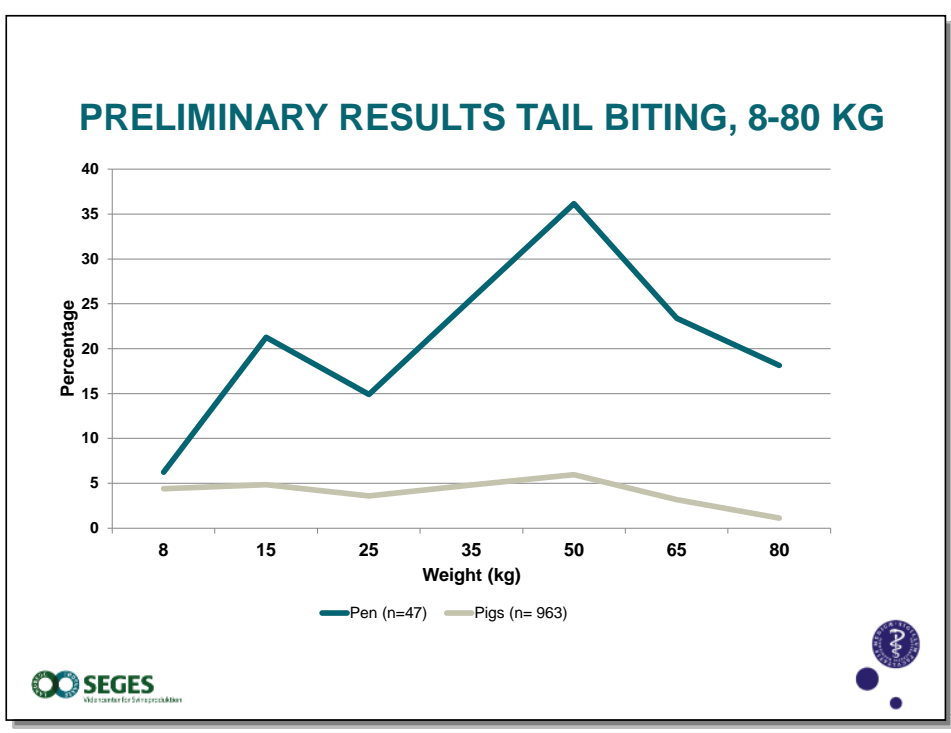

\section{PRELIMINARY CONCLUSIONS}

- Cessation of tail docking in a well managed herd with a high health status and low occurrence of tail biting among docked pigs:

- Increased the risk of tail biting

- despite low stocking density from 7-30 kg and straw

- Increased the need for hospital pens

- Did not increase number of dead pigs - if the tail biting could be stopped

- Abattoir remarks underestimated the prevalence of tail bitten pigs 


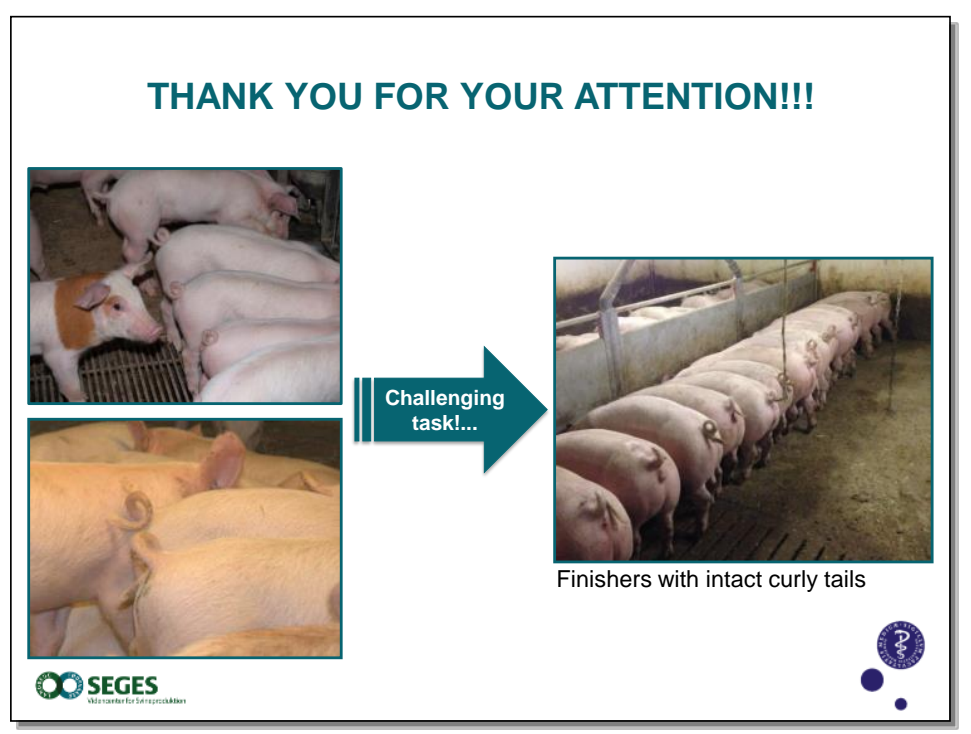


Loose housed sows with low piglet mortality

By Janni Hales Pedersen, Post doc., Department of Large Animal Sciences, University of Copenhagen 

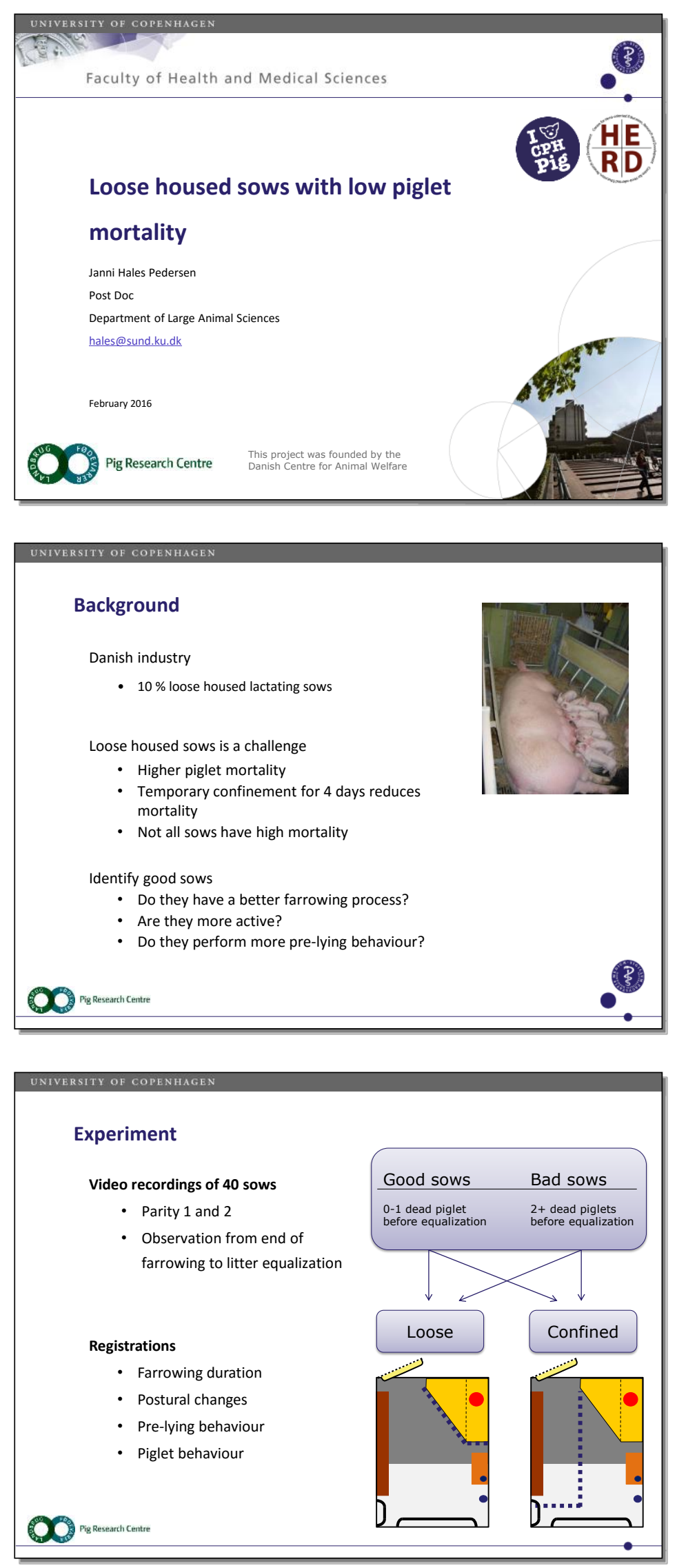
Piglet mortality

- Before litter equalization |- Equalization to day 4 औ Total born piglets

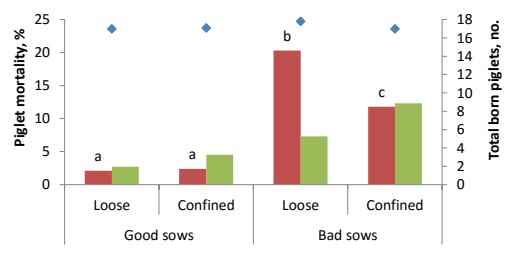

$\infty$

Pig Research Centre

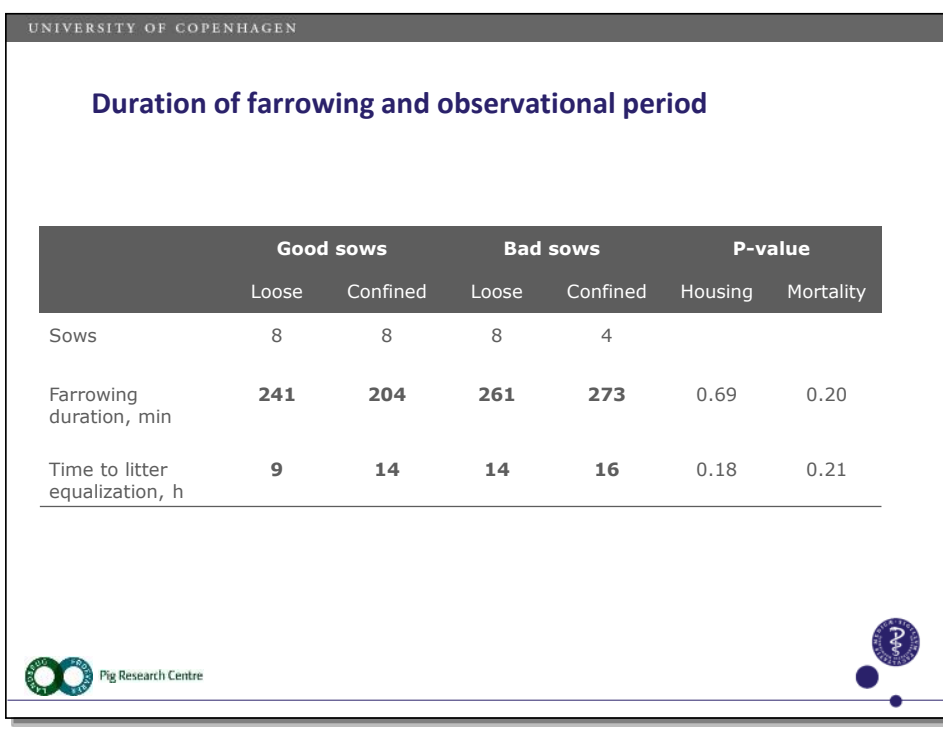

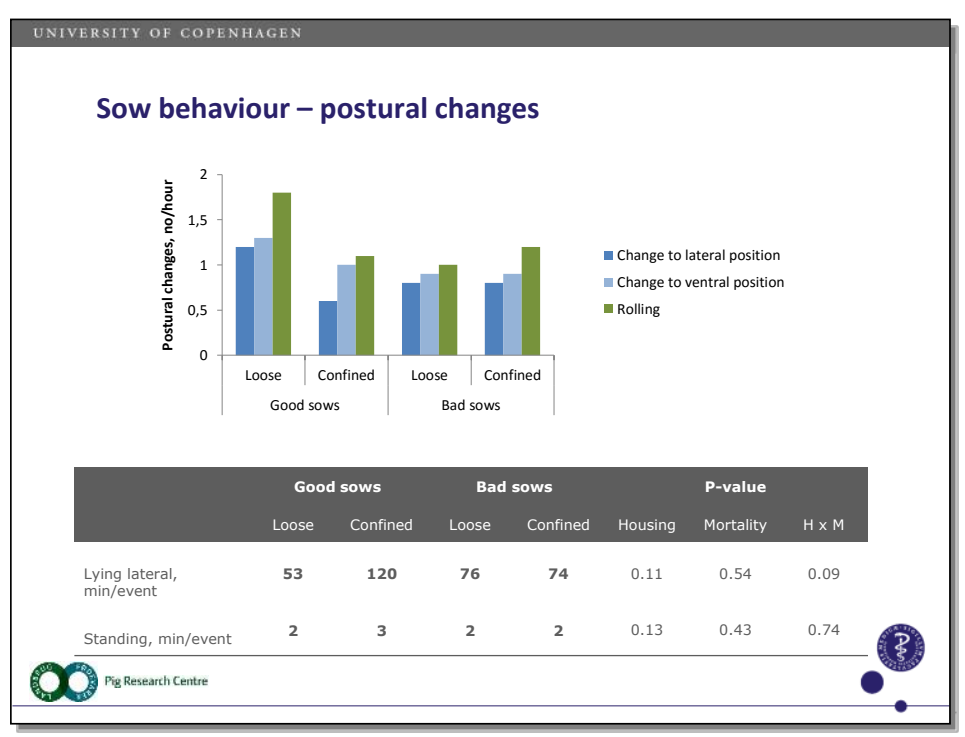



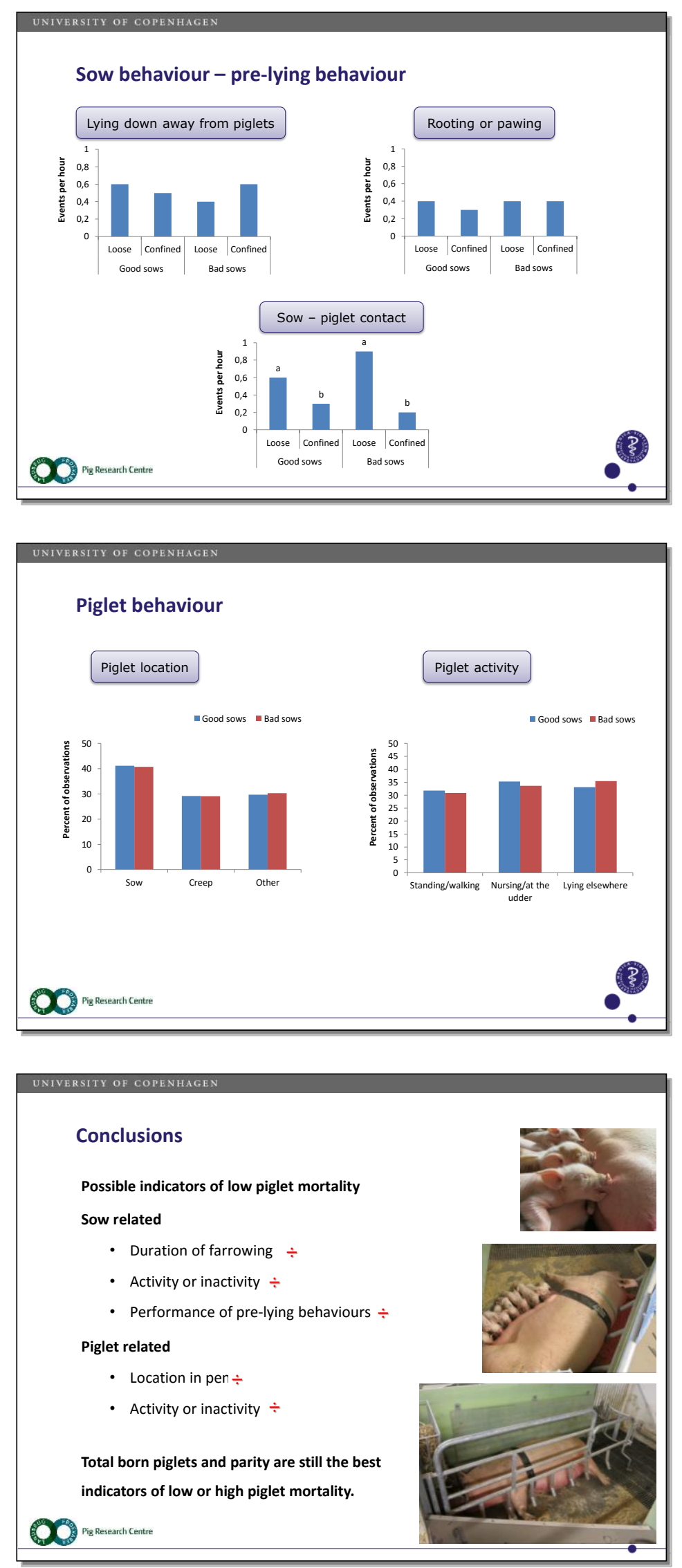


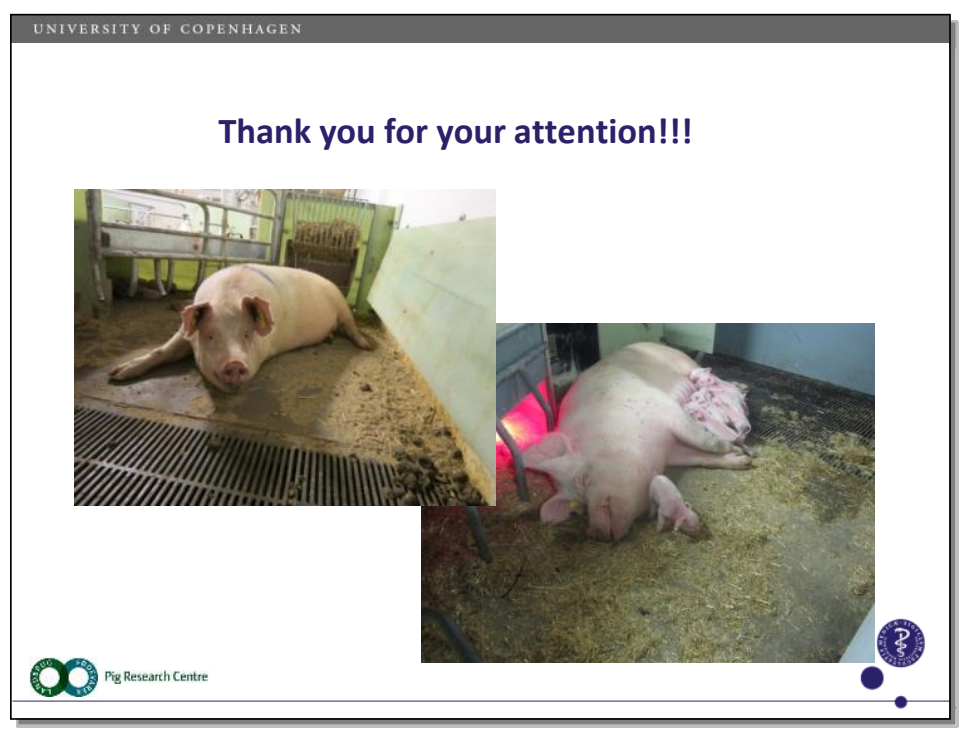


Session 4: MRSA 
Levels of MRSA on pigs and environmental samples

By Julie Elvekjær Hansen, PhD student, DTU National Veterinary Institute 


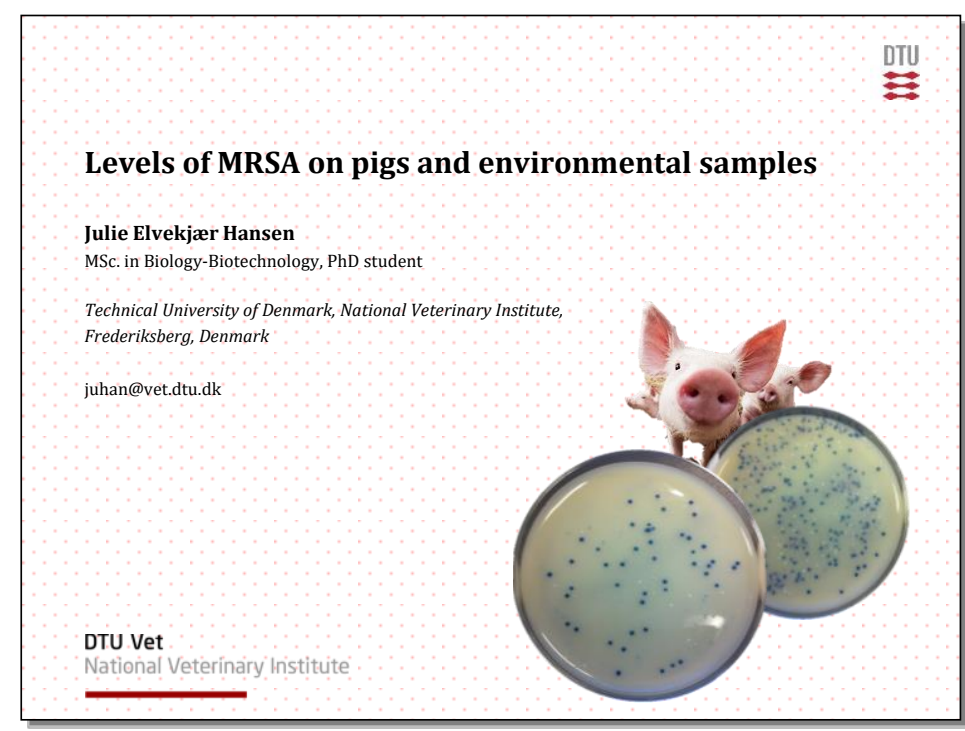

\section{Introduction}

\section{DTU}

LA-MRSA is a public health concern

- Denmark: overall MRSA level is low

- Ambition of maintaining low levels of MRSA

- Increasing prevalence in livestock, especially in pig production - LA-MRSA load not known

- LA-MRSA reservoir - possibility of spread into the general population

- Control and prevention of increasing MRSA level in community

- Assessment of intervention strategies

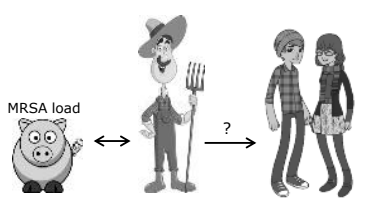

Aims of the study
- To assess the possibilities of quantification of the animal MRSA load by
nasal and skin swab samples
- To test two different active air samplers for quantification of airborne
MRSA as a measure of environmental MRSA load



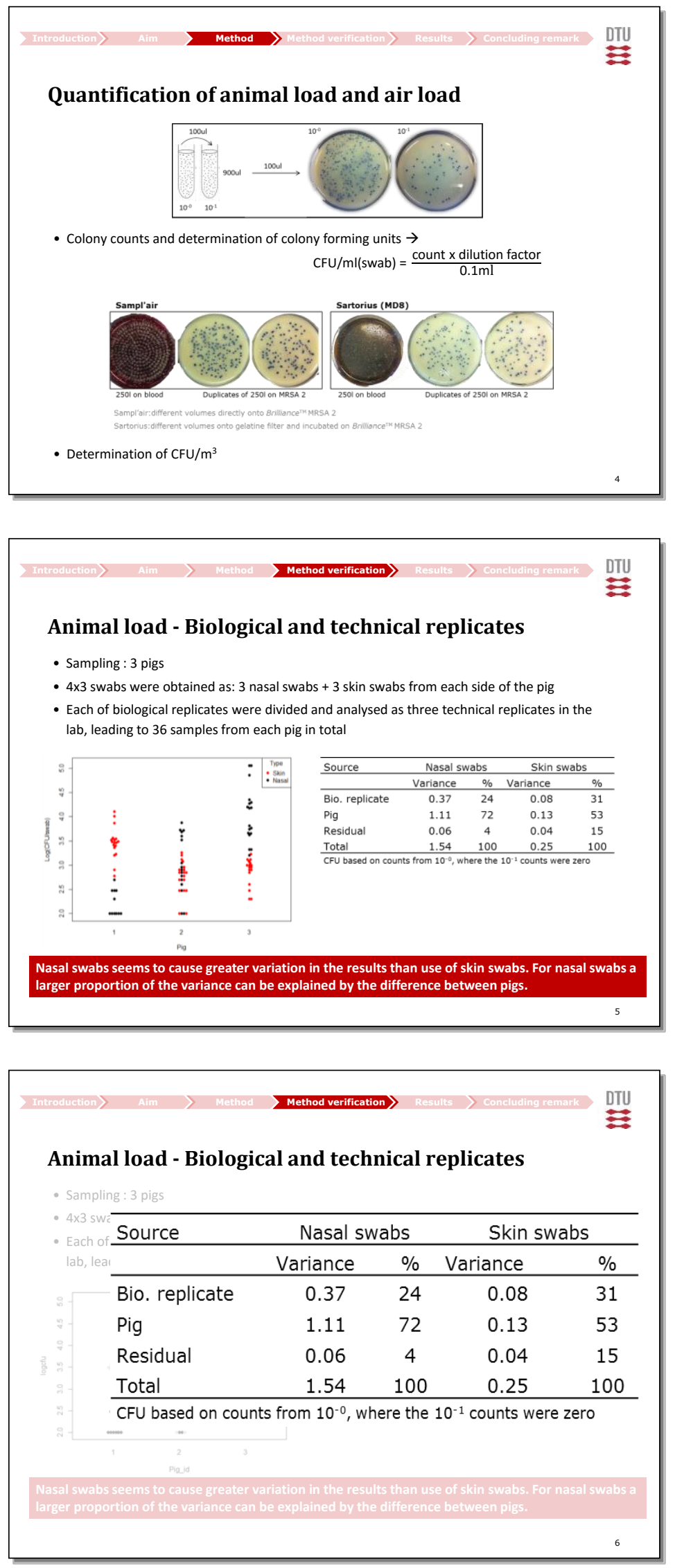

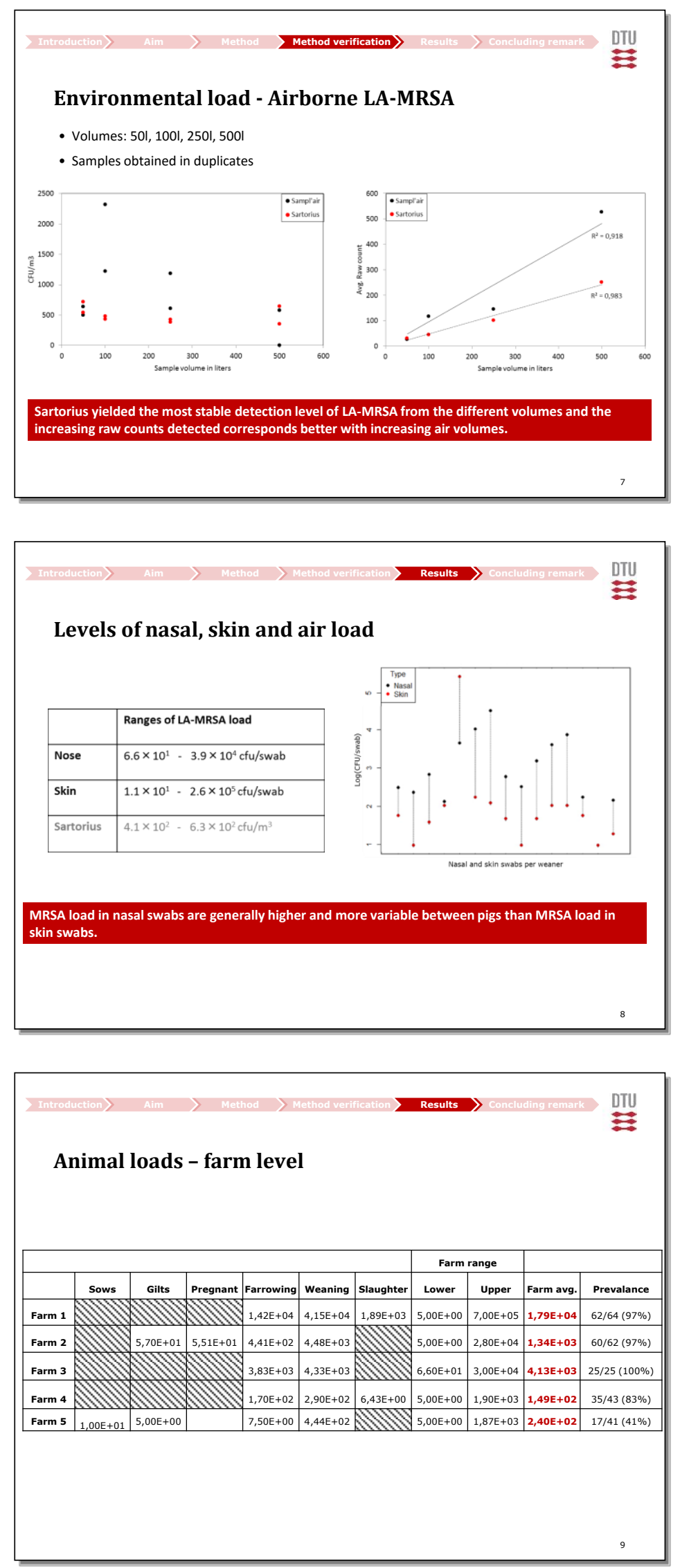


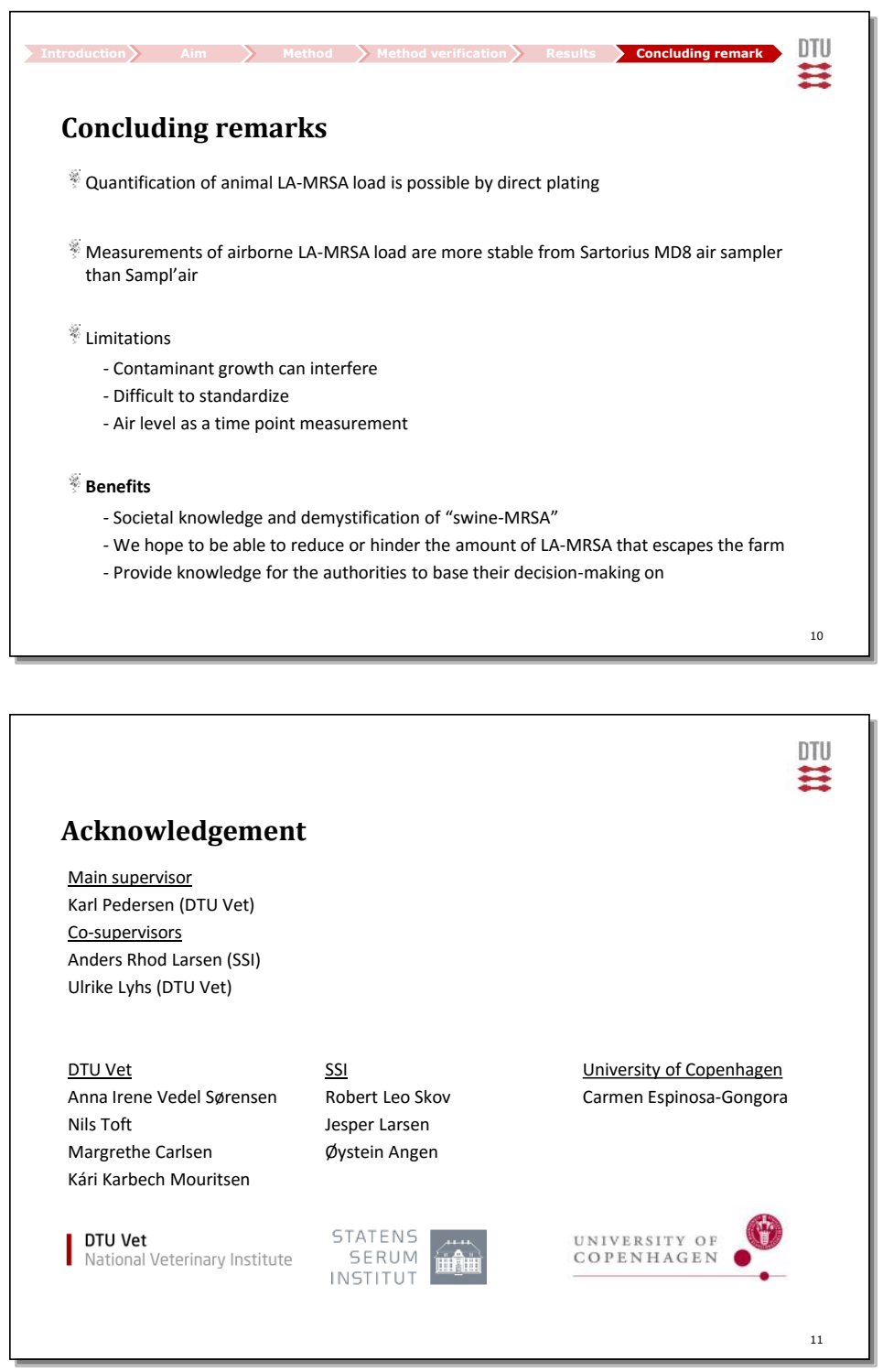


Can we reduce MRSA ST398 in positive farms by eliminating a few pig carriers?

By Carmen Espinosa Gongora, Post doc., Department of Veterinary Disease Biology, University of Copenhagen 


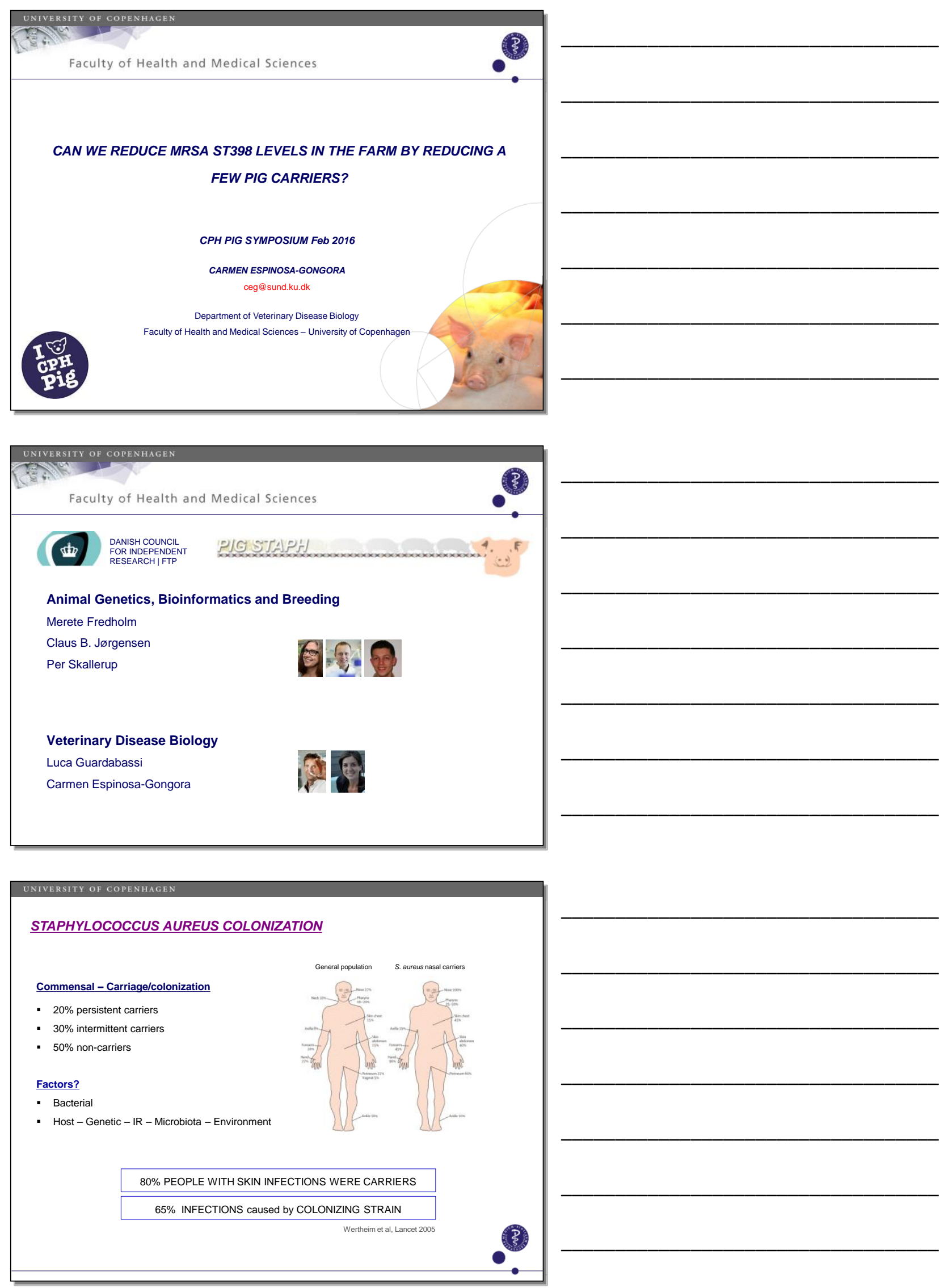



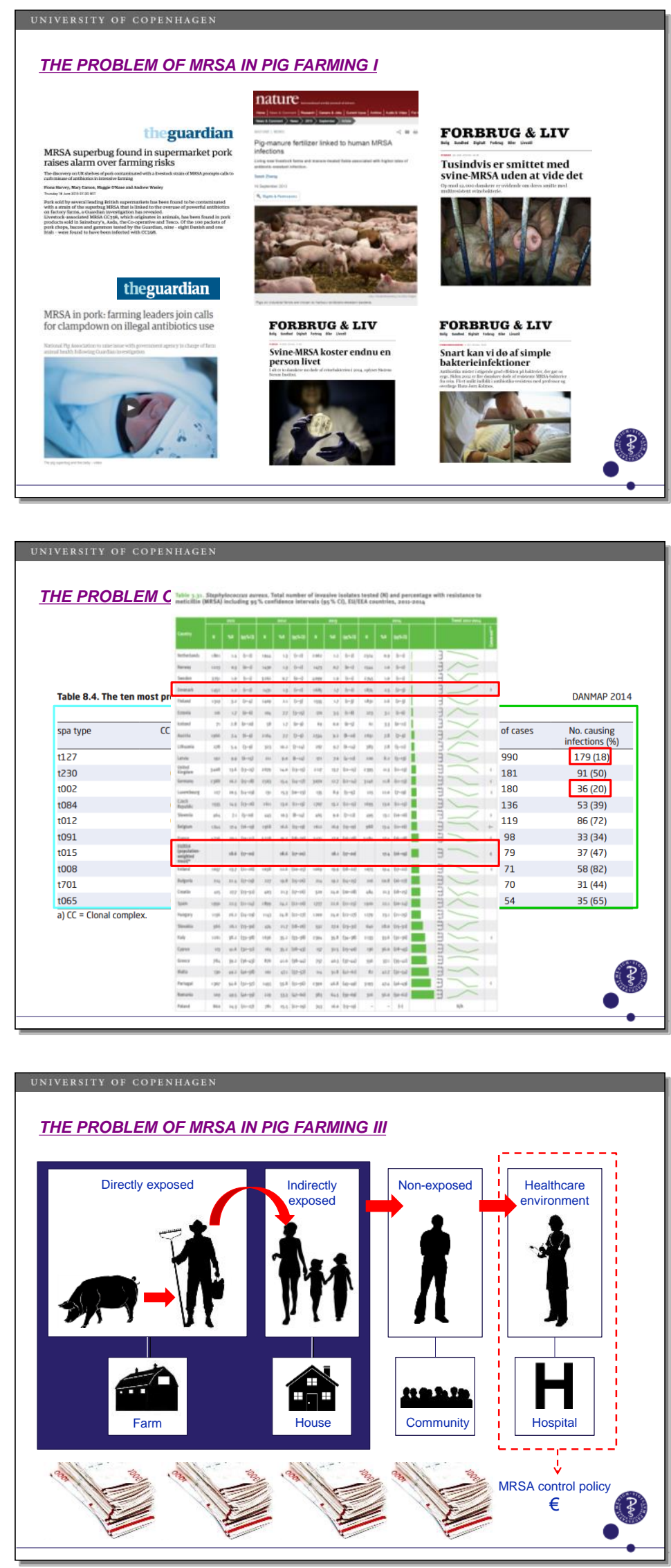

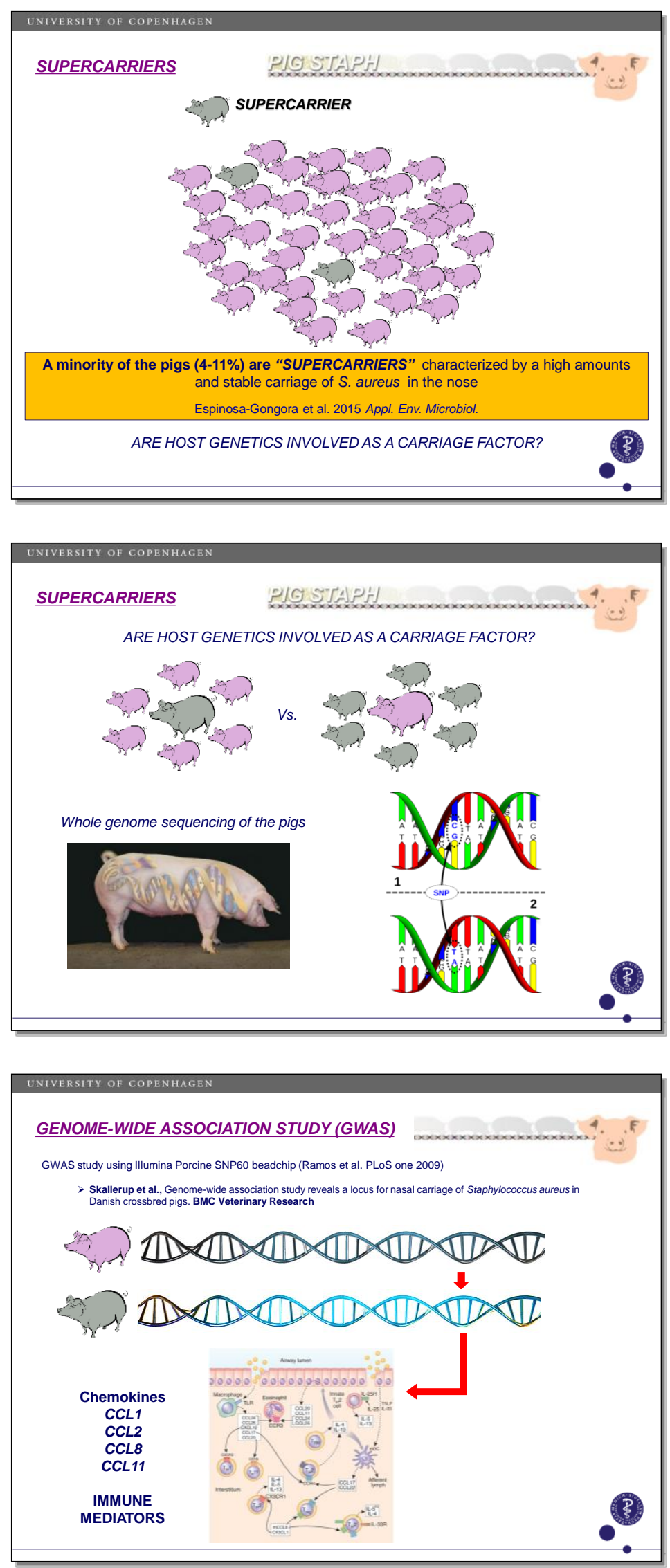

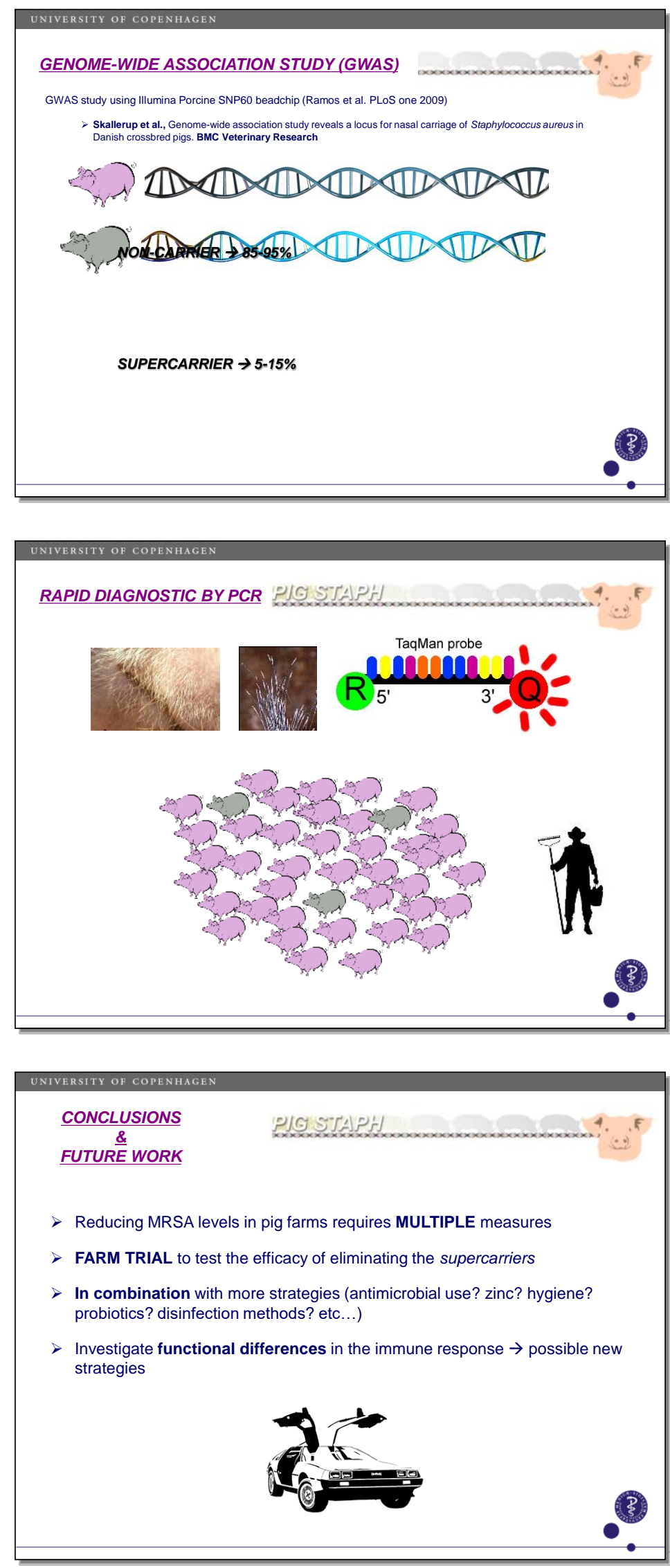


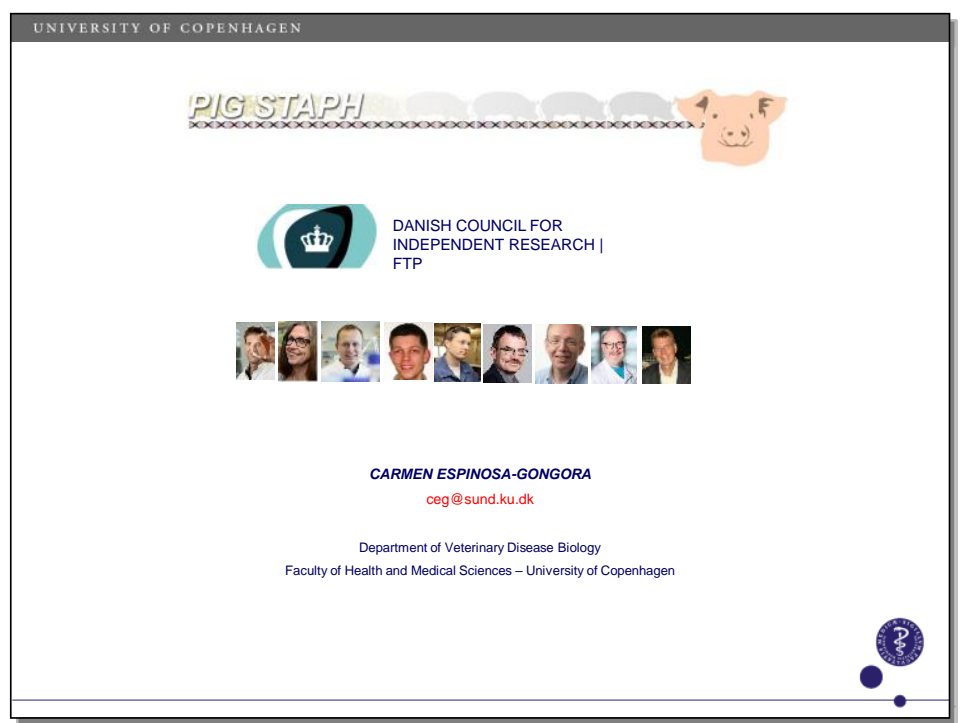


How to pool fecal samples in a cross-sectional study of antimicrobial resistance genes in Danish pig herds

By Anna Camilla Birkegård, PhD student, DTU National Veterinary Institute 
How to pool fecal samples in a

$\stackrel{\text { DTU }}{\rightleftarrows}$ cross-sectional study of antimicrobial resistance genes in Danish pig herds

Julie Clasen, Anders Mellerup, John Elmerdahl Olsen,

Øystein Angen, Anders Folkesson, Tariq Halasa, Nils Toft,

Anna Camilla Birkegård

DTU Vet

National Veterinary Institute

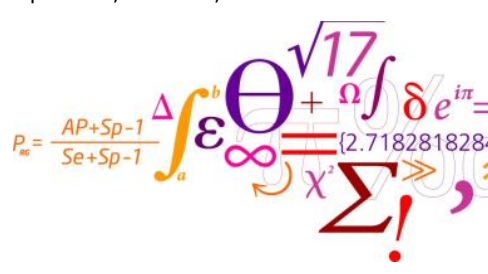

\section{DTU}

Why?

- Level of zoonotic antimicrobial resistance genes in Danish pig herds

- Cross-sectional study

- 500-800 herds

- Spatial randomness

- Short sample period 

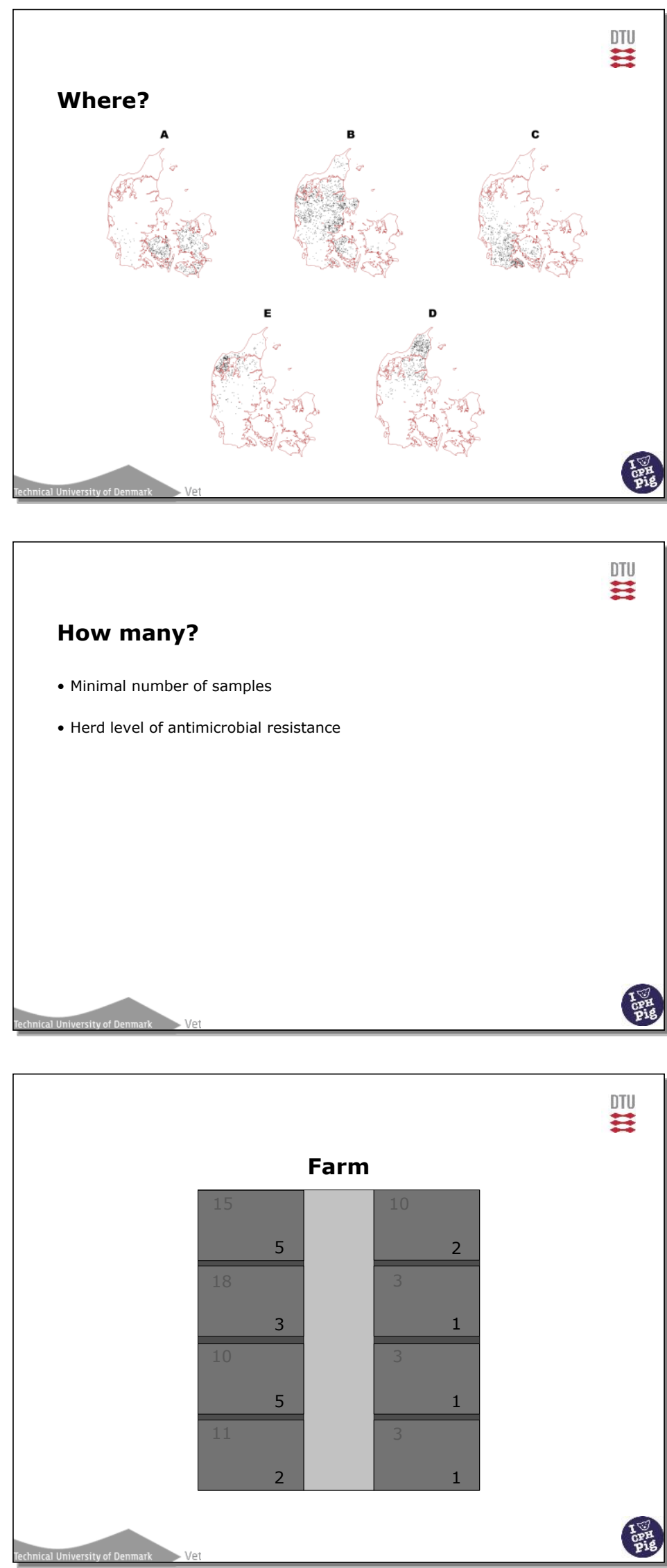


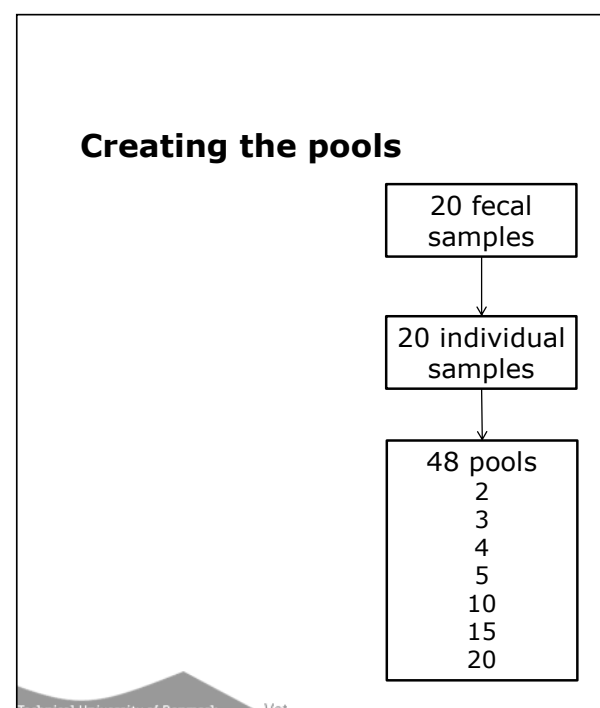

DTU

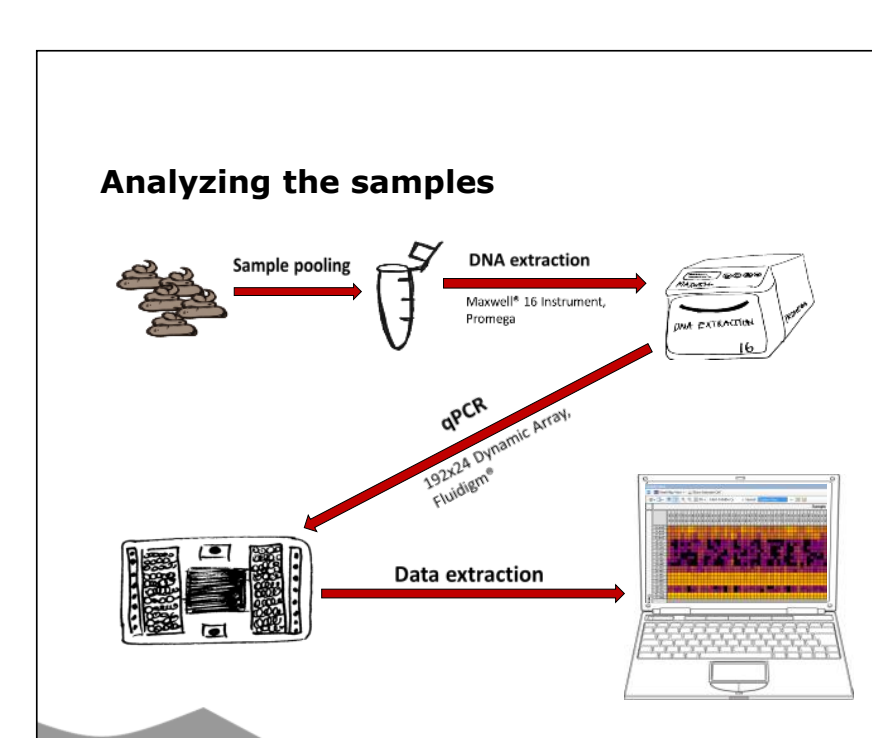

DTU

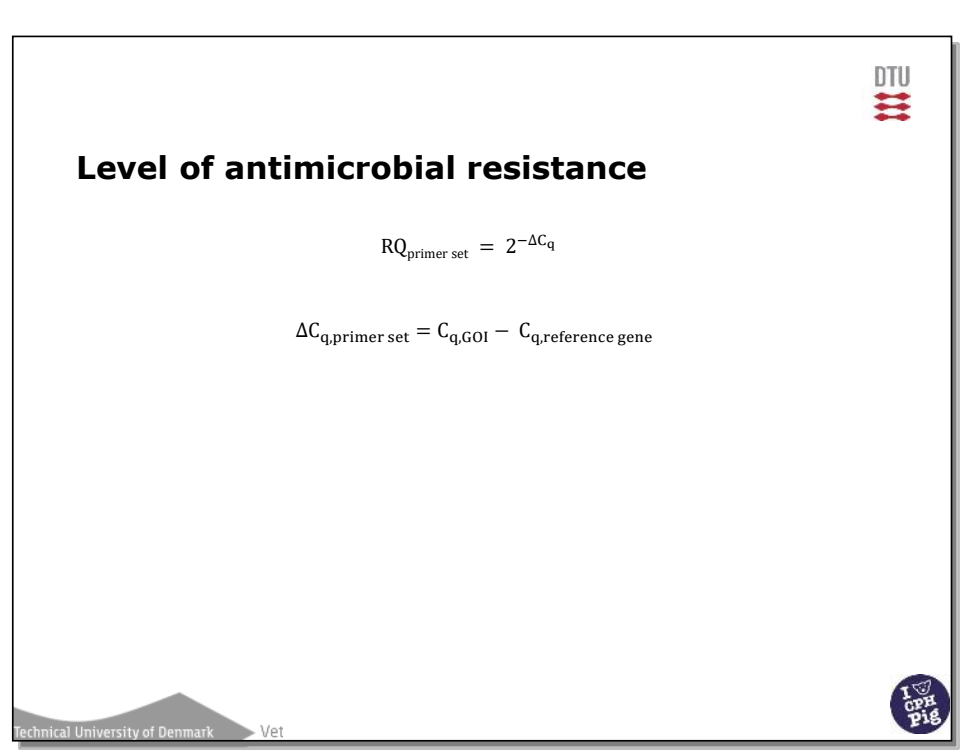




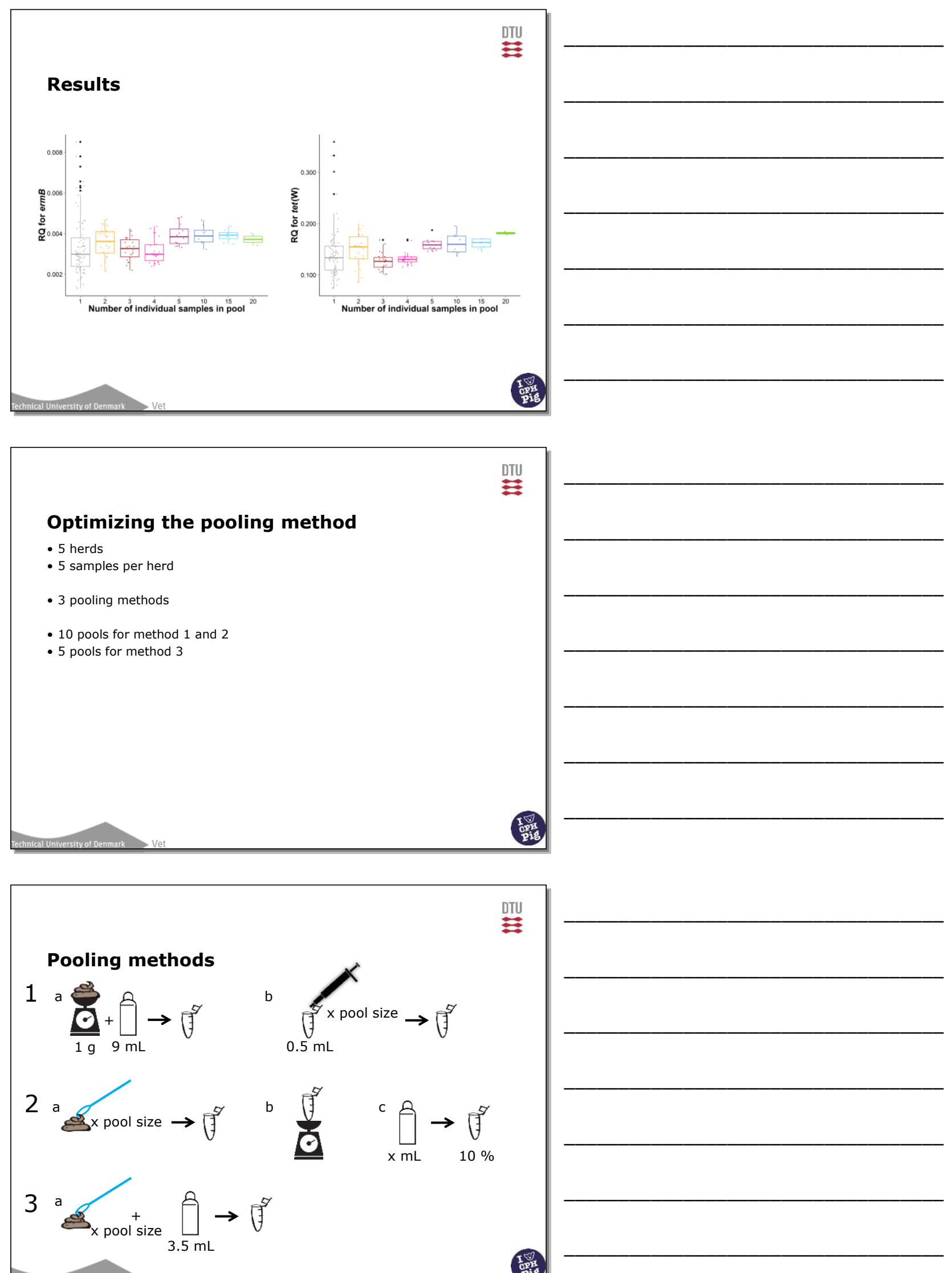




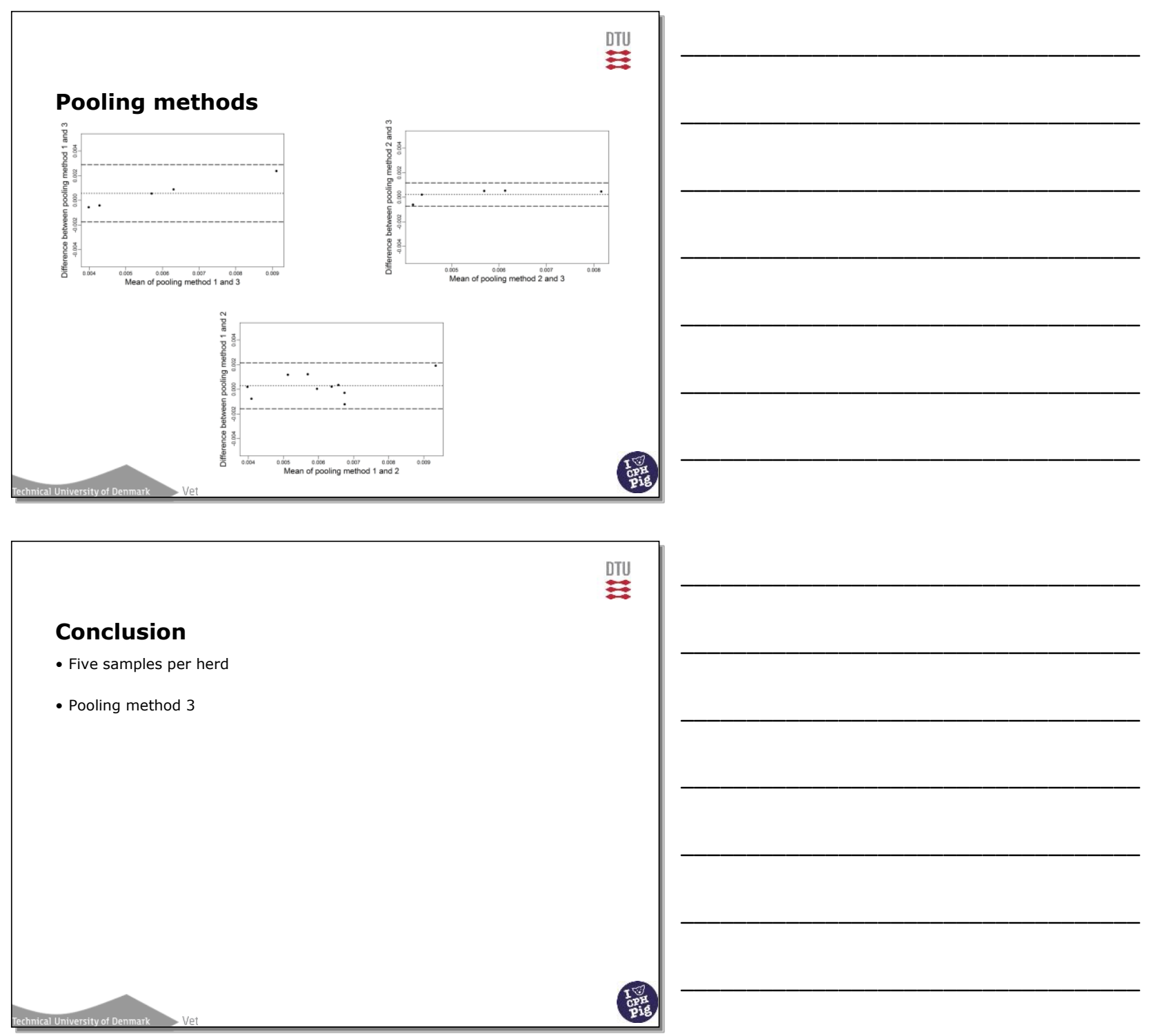


Can pooled faecal samples be used for resistance profiling? -Resistance in E. coli isolates from diarrhoeic nursery pigs

By Nicolai Weber, PhD student, Department of Large Animal Sciences, University of Copenhagen 

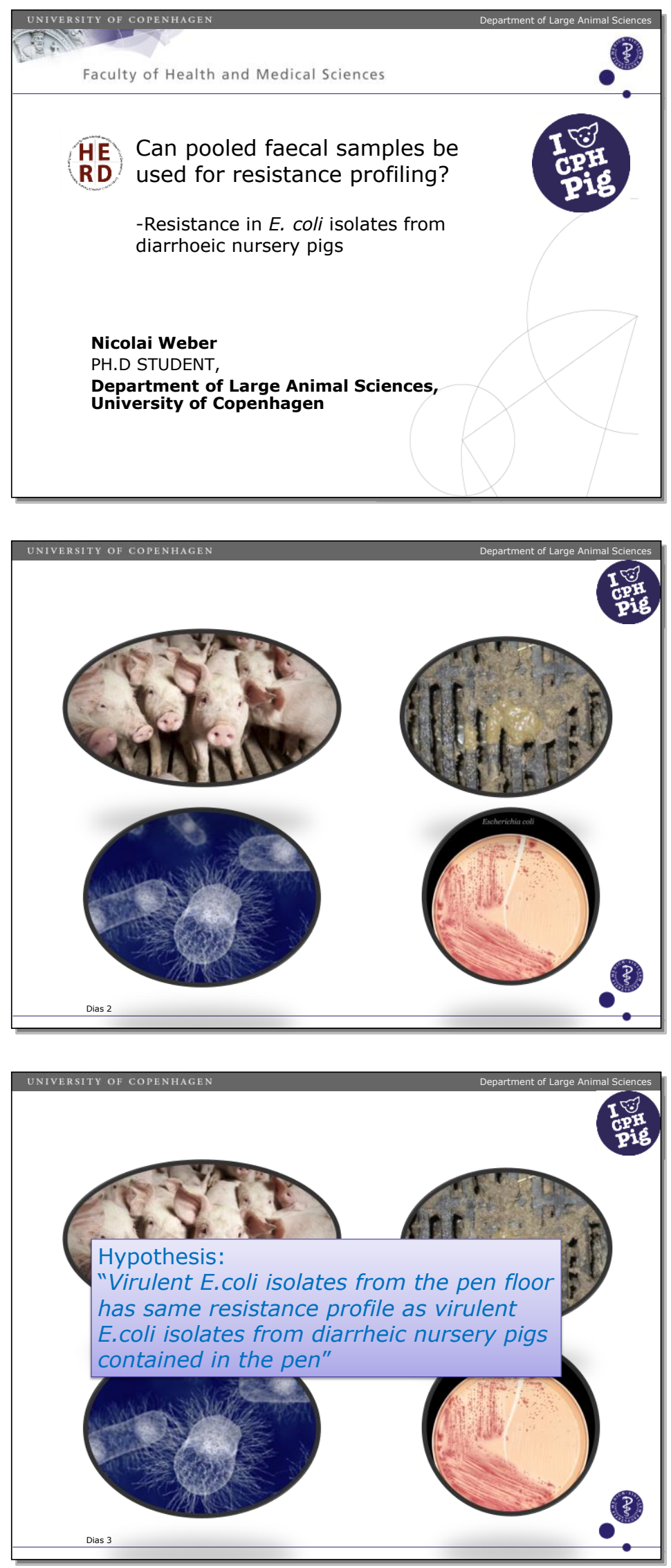

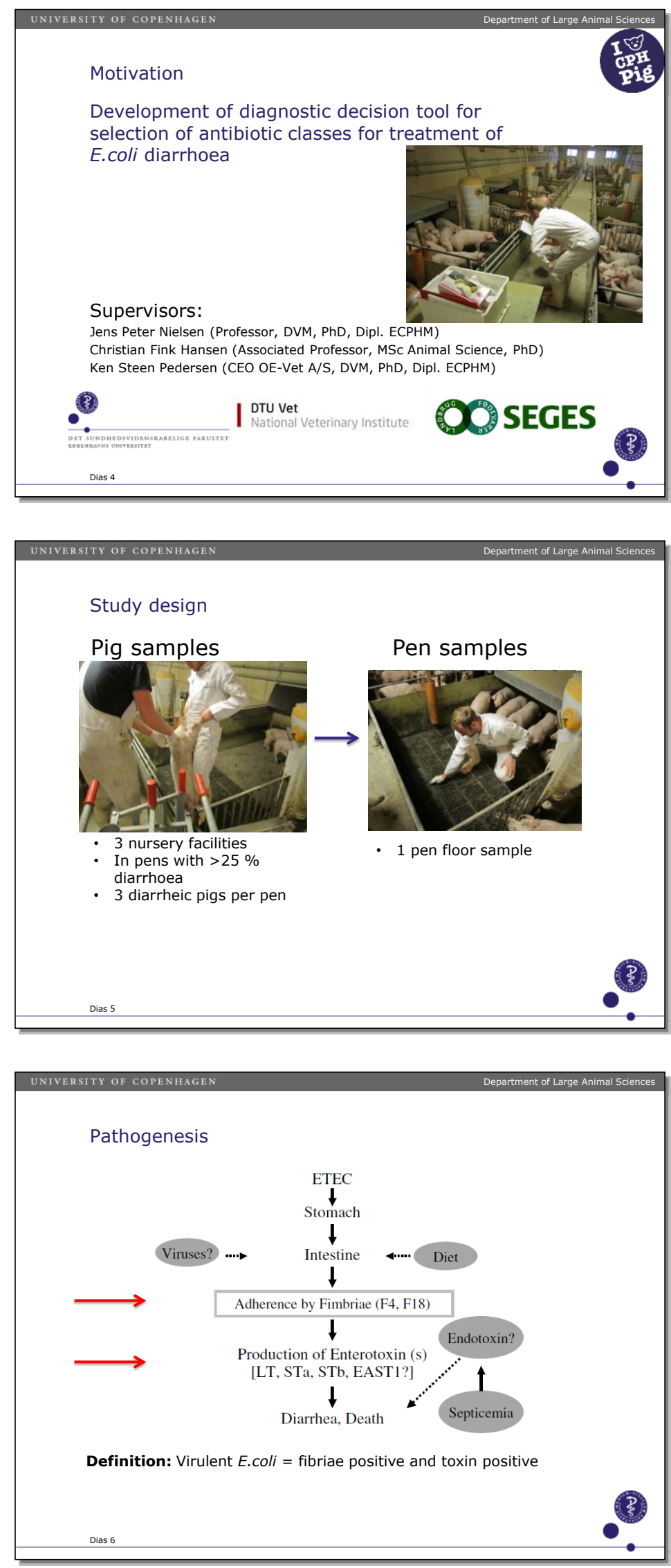


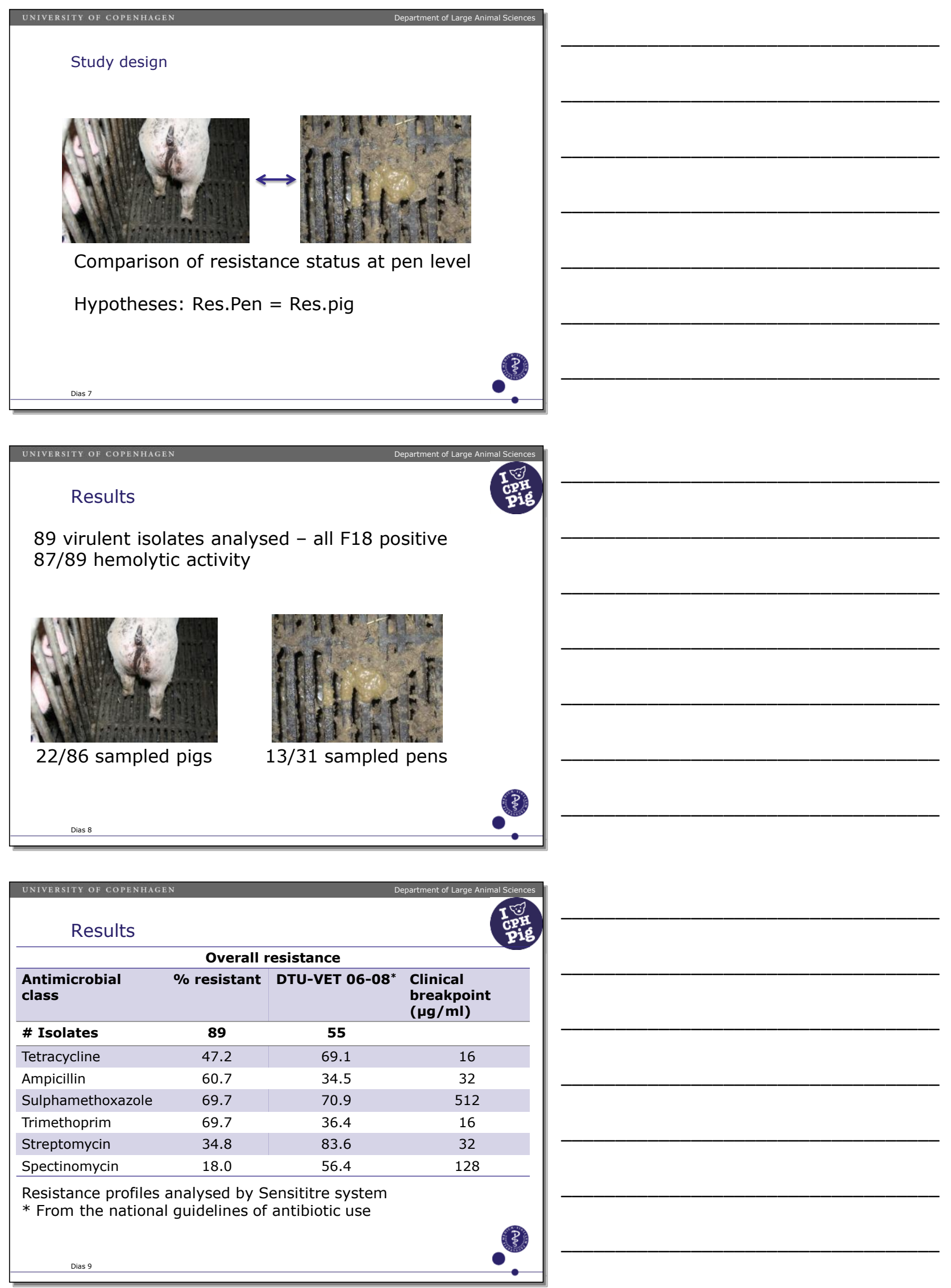




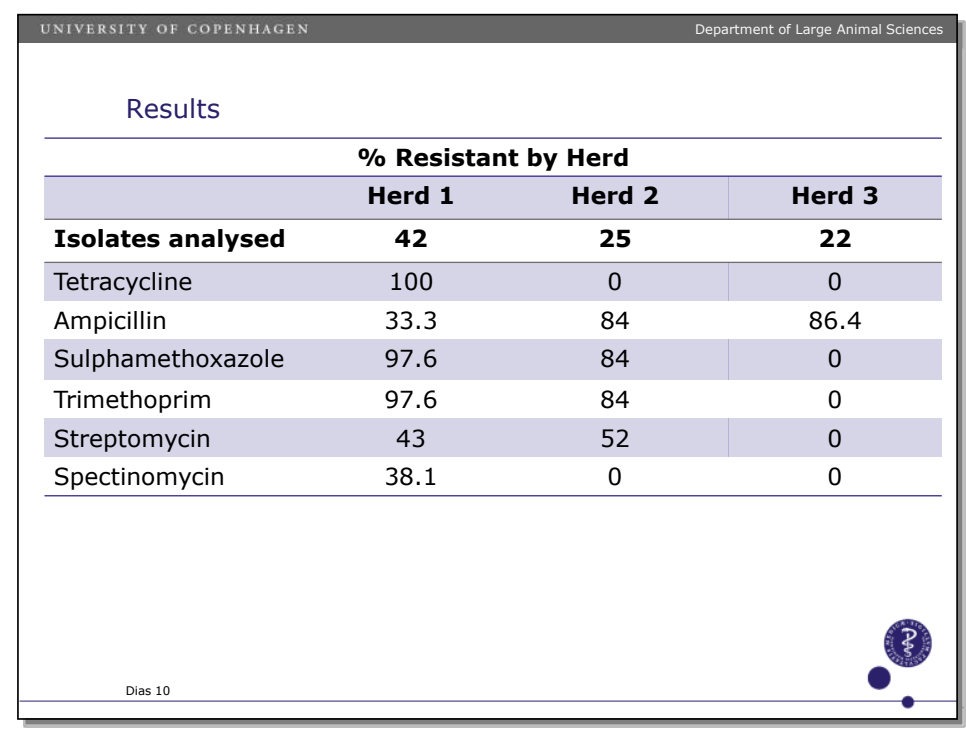

\begin{tabular}{l}
\hline UNIVERSITY OF COPENHAGEN \\
Results
\end{tabular}

\section{Agreement study:}

Definitions:

Res.pig $=1$ or more virulent E.coli isolates from 1 or more pigs for the pen

Res.pen $=1$ or more virulent E.coli isolates from 1 pooled pen floor sample

\begin{tabular}{|c|c|c|c|c|}
\hline \multicolumn{5}{|l|}{ Results } \\
\hline & & \multicolumn{2}{|c|}{ Pig level } & \multirow[b]{2}{*}{ Total } \\
\hline & & + Virulent & - Virulent & \\
\hline \multirow[t]{2}{*}{ Pen level } & + Virulent & 10 & 3 & 13 \\
\hline & - Virulent & 2 & 16 & 18 \\
\hline & Total & 12 & 19 & 31 \\
\hline
\end{tabular}

Sensitivity $=83.3 \%$; Specificity $=84.2 \%$ $\mathrm{PPV}=76.9 \% ; \mathrm{NPV}=88.9 \%$ 


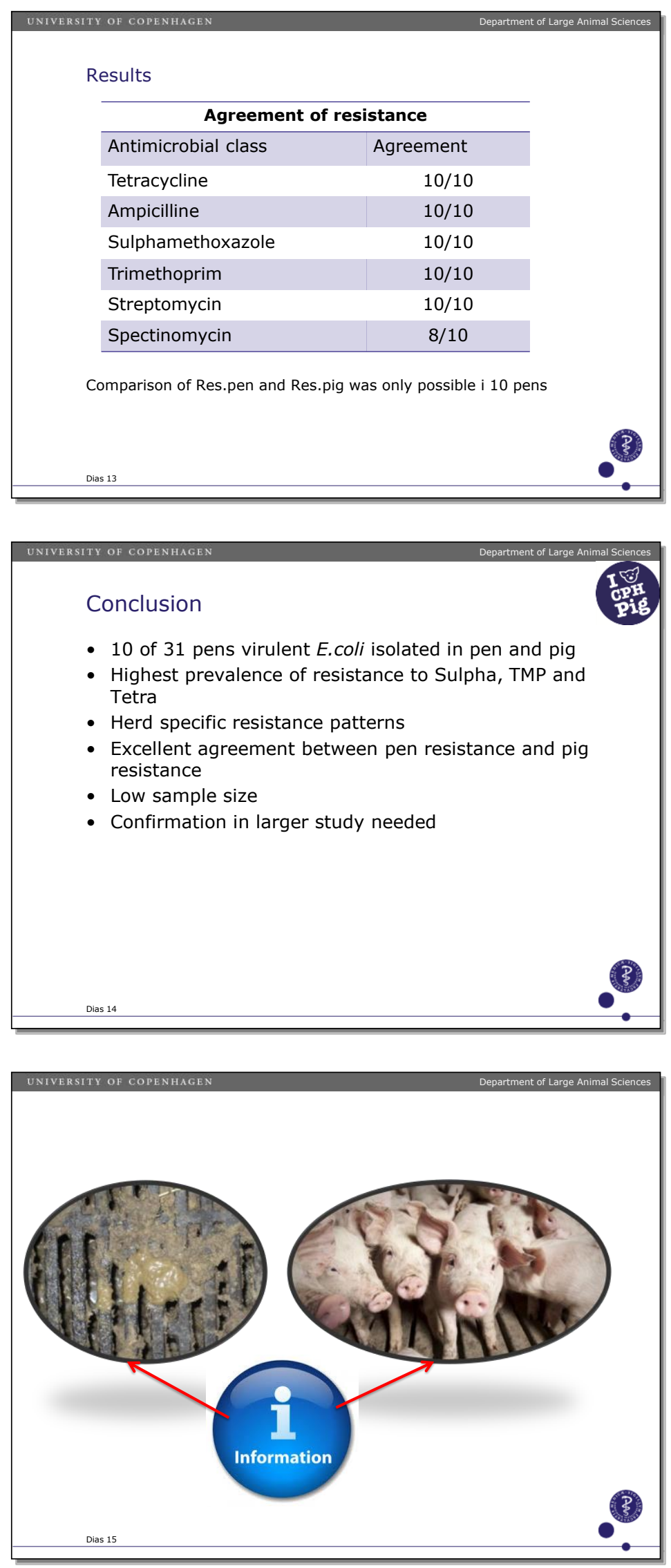


$\mathrm{CPH}$ Pig is financially supported by the Pig Levy Fund (Svineaftgiftsfonden)

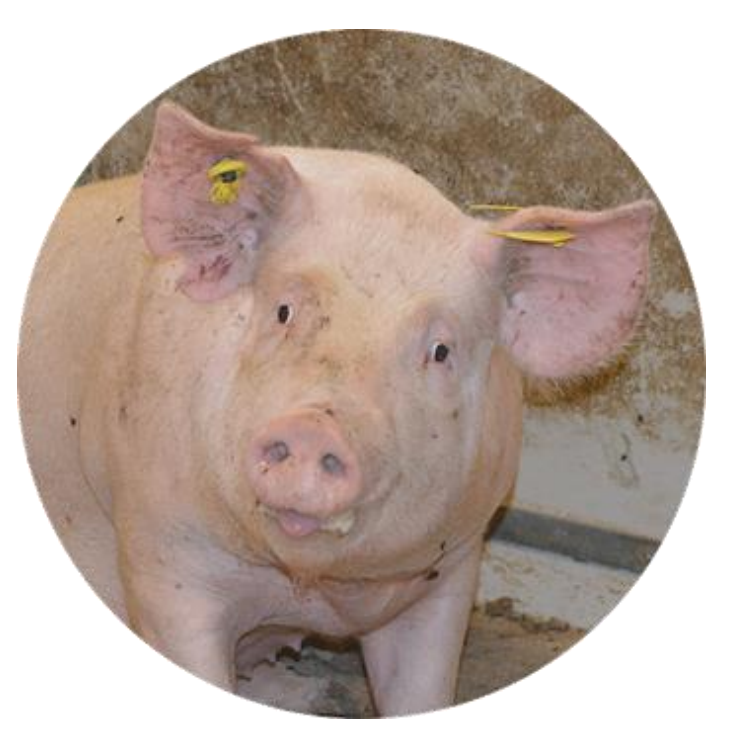

www.svineafgiftsfonden.dk

Thank you for participating

- see you next year!

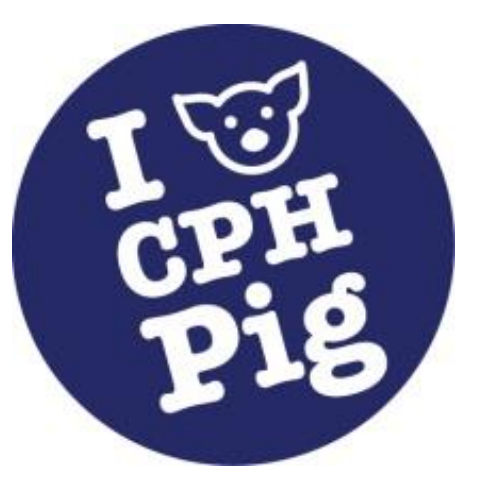


www.cphpig.ku.dk 